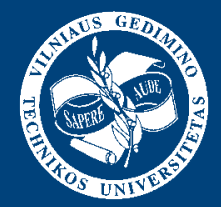

Olga KIZINIEVIČ

Ramuné ŽURAUSKIENE

INOVATYVIOS POLIMERINĖS STATYBINĖS MEDŽIAGOS IR DIRBINIAI 
Olga KIZINIEVIČ

Ramunè ŽURAUSKIENÉ

\section{INOVATYVIOS POLIMERINĖS STATYBINĖS MEDŽIAGOS IR DIRBINIAI}

Mokomoji knyga 


\section{O. Kizinievič, R. Žurauskienė. Inovatyvios polimerinės statybinès} medžiagos ir dirbiniai: mokomoji knyga. Vilnius: Technika, 2012. $104 \mathrm{p}$.

Mokomojoje knygoje aprašytos polimerinès statybinės medžiagos ir dirbiniai. Trumpai pateikta polimerinių statybinių medžiagų kūrimo istorija, gamybos technologijos, savybès, naudojimo galimybès.

Mokomoji knyga skirta studentams, studijuojantiems pagal antrosios pakopos studijų programą Statybos medžiagos ir dirbiniai, ja galès naudotis ir Statybinių medžiagų studijų programos studentai. Taip pat ji bus naudinga pirmosios pakopos nuolatinių ir ištęstinių studijų studentams, studijuojantiems Medžiagotyros, Statybinių medžiagų ir kitas disciplinas. Mokomoji knyga galès būti naudinga rengiant bakalauro ar magistro baigiamuosius darbus.

Recenzavo: Asta Kičaitė, VGTU Statybinių medžiagų katedra,

Darius Zabulionis, VGTU Skaitinio modeliavimo laboratorija

VGTU leidyklos TECHNIKA 1281-S mokomosios metodinès literatūros knyga

http://leidykla.vgtu.lt

ISBN 978-609-457-165-7

eISBN 978-609-457-164-0

doi: $10.3846 / 1281-\mathrm{S}$

(C) Olga Kizinievič, 2012

(C) Ramunė Žurauskienė, 2012

(C) VGTU leidykla TECHNIKA, 2012 


\section{Turinys}

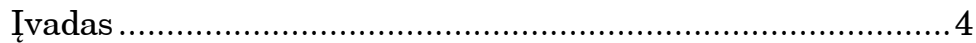

1. Bendros žinios apie polimerus ………………………....... 5

1.1. Makromolekulès ………………........................... 6

1.2. Polimeru sintezè.................................................... 9

1.3. Polimeru klasifikacija............................................. 10

1.4. Plastikų priedai ................................................... 18

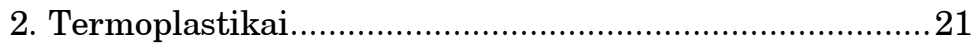

2.1. Polistireninis putplastis (PS) ..............................21

2.2. Polivinilchloridas (PVC)..................................... 36

2.3. Polietilenas (PE) ................................................ 49

2.4. Polipropilenas (PP) ............................................ 59

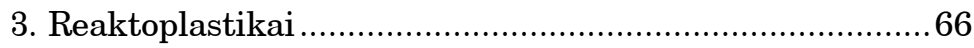

3.1. Polikondensaciniai reaktoplastikai.......................66

3.2. Poliadiciniai reaktoplastikai ................................69

3.3. Polimerizaciniai reaktoplastikai .............................. 73

4. Kompozitinès polimerinès medžiagos ir dirbiniai ............74 74

4.1. Daugiasluoksnès plokštès („sendvič“ tipo)..........75

4.2. Dirbiniai iš medienos ir plastiko kompozitu .......78

4.3. Sluoksniuotieji gaminiai iš plastikų ....................8. 84

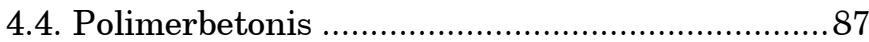

4.5. Polimeriniai dirbiniai, armuoti pluoštais .............90

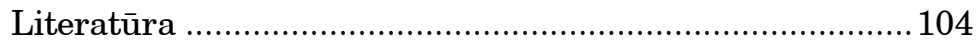




\section{İvadas}

Polimerinès statybinès medžiagos ir dirbiniai šiuolaikiniame pasaulyje vis dažniau pakeičia tradicines natūralias medžiagas. Polimerinių statybinių medžiagų poreikis nuolat auga, kuriama vis daugiau šių medžiagu rūšių. Žinios apie polimerines statybines medžiagas ir dirbinius bei iš ju sudarytus kompozitus reikalingos tiek specialistams, gaminantiems, projektuojantiems ir statantiems, tiek šiu medžiagų vartotojams.

Mokomosios knygos pradžioje pateikiamos bendrosios žinios apie polimerus ir jų gamybos technologijas. Toliau aprašomos termoplastinès ir reaktoplastinès polimerinès medžiagos, jų žaliavos, gavimas, naudojimas.

Taip pat mokomojoje knygoje apibūdinti kompozitinių polimerinių medžiagų ir dirbinių kūrimo metodai, dirbinių savybės, naudojimo galimybès.

Autorių nuomone, mokomoji knyga gali būti naudinga Lietuvos universitetu ir kolegijų studentams, studijuojantiems Medžiagotyros, Statybinių medžiagų, Statybinių polimerų ir Polimerinių medžiagų bei dirbinių disciplinas, rengiantiems baigiamuosius darbus.

Dẻkojame recenzentams už vertingus siūlymus ir pastabas. 


\section{BENDROS ŽINIOS APIE POLIMERUS}

Polimerais vadinami stambiamolekuliai junginiai, susidedantys iš daug kartų pasikartojančių vienodų arba skirtingų atomų grupių mažos molekulinès masès junginių - monomerų, tarp kurių veikia kovalentinio ryšio jègos. Polimero pavadinimas susideda iš dvieju dalių: priešdèlio poli- ir grandinès sandaros grandžių pavadinimų (pvz., polimeras, gautas iš etileno (eteno), vadinamas polietilenu, iš stireno - polistirenu). Polimerai yra pagrindine ir svarbiausioji plastikų, arba plastmasių, dalis. Žinių apie polimerus nuolat gausejja ir jos yra nuolat atnaujinamos. Šiuo metu pasaulyje nèra žmogaus veiklos srities, kuriose nebūtų naudojama polimerų arba jų gaminių. Polimerai yra sudaryti iš ilgu, lanksčiuc, asimetrinių, galinčių keisti pavidalą makromolekulių. Tarp molekulių pasireiškia tarpmolekulinė sąveika. Polimerai nèra vienalyčiai, juose gali būti ir kristalinių, ir amorfinių sričiuc. Ištirpę polimerai sudaro tikruosius tirpalus. Tikrieji - tai tokie, kuriuose yra tolygiai pasiskirstę tirpinio atomai, molekulès ar jonai.

Polimerinių statybinių medžiagu ir dirbinių paklausa, gamyba ir naudojimas didèja, nes jiems būdingos tokios fizikinès-mechaninès ir technologinès savybès, kurių neturi tradicinès medžiagos. Kartu su metalais, keramika ir mediena polimerai yra svarbi statybinių medžiagu grupè. Per pastaruosius 10 metu polimerinių statybinių medžiagų gamyba išaugo 12 kartų. Statybinių medžiagu pramonèje kasmet naudojama daugiau nei $30 \%$ visų pasaulyje pagamintų plastikų. Polimerai susidaro cheminių ir terminių procesų metu, tačiau temperatūros ir energijos sąnaudos jiems pagaminti dažniausiai būna gerokai mažesnès nei tradicinių statybinių medžiagų. Polimerai yra ivairaus tankio (nuo 800 iki $2000 \mathrm{~kg} / \mathrm{m}^{3}$, putplasčių - tik viena ar kelios dešimtys $\mathrm{kg} / \mathrm{m}^{3}$ ), ju labai ịvairios mechaninès (pvz., elastomerai, armuotieji plastikai) ir optinès (pvz., poliakrilatiniai, epoksidiniai plastikai) savybès. Yra polimeru, kurie atsparūs ne tik atmosferos, bet ir cheminių medžiagų poveikiui. 


\subsection{Makromolekulès}

Makromolekulès (gr. makros - didelis, ilgas, lot. molecula maža masè) yra ypatinga molekulių rūšis. Makromolekules sudaro tūkstančiai ar šimtai tūkstančiu atomų. Kiekvienoje makromolekulëje yra bent viena grandinè. Atomai grandineje sujungti nepoliniais ir (arba) poliniais kovalentiniais ryšiais. Dèl aktyviujų centru gausos sąveika tarp makromolekulių yra daug stipresnè negu mažamolekuliu junginių tarpmolekulinè sąveika. Dèl ypatingos makromolekuliu sandaros iš jų sudarytos medžiagos (polimerai) ir jų savybès labai skiriasi nuo kitų mažamolekulių medžiagų ir savybių.

Kiekvienos makromolekulès grandinę sudaro grandys. Skiriamos sandaros ir monomero grandys. Makromolekules sudaro i grandines susijungusios monomeru grandys. Sandaros grandi sudaro polimere nuosekliai besikartojantys viena tvarka sujungti grandinès atomai arba atomu grupès. Pvz., polietileno sandaros grandis yra $-\mathrm{CH}_{2}$, jo monomero grandis $-\mathrm{CH}_{2}-\mathrm{CH}_{2}$. Kai kurių polimeru grandiniu grandys ir monomerai pateikti 1.1 lenteleje.

Monomero grandžiu skaičius makromolekulèje vadinamas polimerizacijos laipsniu. Pažymèjus polimerizacijos laipsni raide $P$, priklausomybè tarp makromolekulès molekulinès masès $(M)$ ir monomero grandies molekulinès masès $(m)$, bus tokia:

$$
M=m \cdot P,
$$

čia $M$ - makromolekulès molekulinè masé; $m$ - monomero grandies molekulinè masé; $P$ - polimerizacijos laipsnis.

Polimerų formulèse polimerizacijos laipsnis paprastai žymimas raide $n$. Pvz., polipropileno makromolekulès, kurios $P=1000$, santykinè molekulinè mase $M=42000$. Polimero polimerizacijos laipsnio ir jo molekulinès masès vertès yra vidutinès.

Polimerams būdinga tai, kad mažiausia dalelè reakcijose gali būti ne tik makromolekulè, bet ir jos grandinès atkarpa, arba grandis.

Pagal geometrinę formą makromolekulès skirstomos i linijines, šakotasias ir tinklines (erdvines). 
1.1 lentelè. Kai kurių polimerų grandinių grandys ir monomerai

\begin{tabular}{|c|c|c|c|c|}
\hline Polimeras & Monomeras & $\begin{array}{l}\text { Monomero } \\
\text { grandys }\end{array}$ & $\begin{array}{l}\text { Sandaros } \\
\text { grandys }\end{array}$ & $\begin{array}{l}\text { Gran- } \\
\text { dinès } \\
\text { atomai }\end{array}$ \\
\hline $\begin{array}{l}\text { Poli- } \\
\text { etilenas }\end{array}$ & $\mathrm{CH}_{2}=\mathrm{CH}_{2}$ & $-\mathrm{CH}_{2}-\mathrm{CH}_{2}-$ & $-\mathrm{CH}_{2}-$ & $\mathrm{C}$ \\
\hline $\begin{array}{l}\text { Poli- } \\
\text { propilenas }\end{array}$ & $\begin{array}{c}\mathrm{CH}_{2}= \\
\mathrm{CH}\left(\mathrm{CH}_{3}\right) \\
\end{array}$ & $-\mathrm{CH}_{2}-\mathrm{CH}\left(\mathrm{CH}_{3}\right)-$ & $\begin{array}{c}-\mathrm{CH}_{2}-\mathrm{ir} \\
-\mathrm{CH}\left(\mathrm{CH}_{3}\right)- \\
\end{array}$ & $\mathrm{C}$ \\
\hline $\begin{array}{l}\text { Poli- } \\
\text { stirenas }\end{array}$ & $\begin{array}{c}\mathrm{CH}_{2}=\mathrm{CH} \\
\mathrm{I} \\
\mathrm{C}_{6} \mathrm{H}_{5}\end{array}$ & $\begin{array}{c}-\mathrm{CH}_{2}-\mathrm{CH}- \\
\mathrm{I} \\
\mathrm{C}_{6} \mathrm{H}_{5}\end{array}$ & $\begin{array}{c}-\mathrm{CH}_{2}-\mathrm{ir} \\
-\mathrm{CH}- \\
\text { । } \\
\mathrm{C}_{6} \mathrm{H}_{5} \\
\end{array}$ & $\mathrm{C}$ \\
\hline $\begin{array}{l}\text { Polivi- } \\
\text { nilchlo- } \\
\text { ridas }\end{array}$ & $\mathrm{CH}_{2}=\mathrm{CHCl}$ & $-\mathrm{CH}_{2}-\mathrm{CHCl}-$ & $\begin{array}{c}-\mathrm{CH}_{2}-\mathrm{ir} \\
-\mathrm{CH}- \\
\mathrm{I} \\
\mathrm{Cl}\end{array}$ & $\mathrm{C}$ \\
\hline
\end{tabular}

Linijiniu makromolekulių grandinès yra ilgos (-M-M-M-M$\mathrm{M}-\mathrm{M}-$ ) ir neturi atšakų (pvz., polietilenas $\left.\left(-\mathrm{CH}_{2}-\mathrm{CH}_{2}-\right)_{n}\right)$, čia M yra monomero molekulè, o brūkšneliais pažymėtas - cheminis ryšys. Linijiniuose polimeruose susijungę monomerai sudaro ilga grandinę. Tokio polimero struktūrą sudaro daugybè linijinių makromolekulių, tarp kurių veikia tarpmolekulinès jègos, turinčios didelę itaką polimero tankiui ir jo mechaninėms savybèms.

Šakotosiose makromolekulèse prie pagrindinès grandinès yra prisijungusios ivvairaus ilgio atšakos - šoninès grandinès (1.1 pav.). Atšakų cheminè sudètis gali būti tokia pati, arba kaip yra skiepytujuc kopolimerų atveju, skirtis nuo pagrindinès grandinès grandžių cheminès sudèties. Tačiau atšakomis negali būti laikomi net ir daugiaatomiai monomero grandžių $H$ pakaitai. Šakotosios struktūros polimeruose tarpmolekulinès jègos yra silpnesnès.

Šakotosios ir linijinès makromolekulès apibūdinamos pagal ju vidutinę molekulinę masę $\bar{M}$ ir cheminę sudèti. Šakotosios makromolekulès turi dar vieną jas apibūdinanti parametrą - šakotumo laipsni. Jis parodo atšakų skaičių atkarpoje, kurią sudaro 1000 pagrindinès grandinès atomų. 


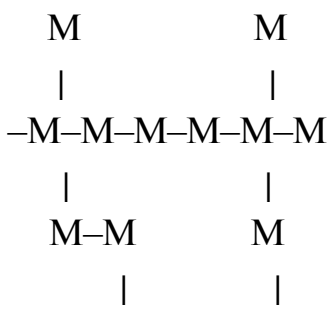

1.1 pav. Šakotosios struktūros makromolekulès

Mažo tankio polietileno makromolekulių atkarpose yra nuo 20 iki 40 atšakų. Tokio polimero savybès labai skiriasi nuo didelio tankio polietileno savybių, kurio makromolekulès 100 anglies atomų ilgio pagrindinès grandinės atkarpoje vidutiniškai yra 5-10 atšakų.

Tinklinèse (erdvinése) makromolekulèse kai kurie kaimyninių grandinių atomai tarpusavyje sujungti (susiūti) kovalentiniais ryšiais arba atomų grandinèlèmis - tilteliais (1.2 pav.).

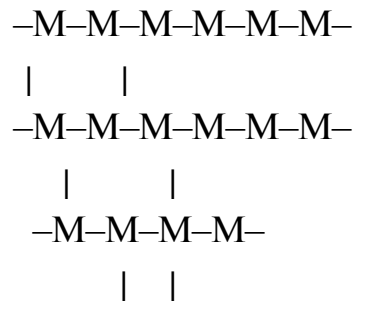

1.2 pav. Tinklinès struktūros makromolekulès

Netvarkingai susiūtos tinklinès makromolekulès atsiranda dèl polimerų sintezès metu vykstančių šalutinių reakcijų arba tarp linijinių ir šakotujų makromolekulių susidarius naujiems skersiniams ryšiams, kuriuose yra keletas arba keliolika atomų, kurie gali būti kitokie nei pagrindinèje grandinèje.

Yra dvi polimerų fazinès būsenos - amorfine ir kristalinè.

Amorfiné. Linijinių polimerų struktūra netvarkinga - jų grandinès susisukusios ir susipynusios. Šios būsenos gali būti kieti ir skysti polimerai. 
Kristalinè. Polimeru molekulès yra gana ilgos, lanksčios, todèl kai kurios šių grandžių zonos gali būti išsidèsčiusios tvarkingai (tokios zonos savybèmis primena kristalus). Kristalinès būsenos būna tik kietosios agregatinès būsenos polimerai. Praktikoje abu būviai egzistuoja kartu, nes vien kristalinio būvio išgauti nepavyksta.

\subsection{Polimerų sintezè}

Stambiamolekuliai junginiai gali būti išskirti iš gamtinių medžiagų, gauti chemiškai modifikuojant polimerus arba susintetinti iš mažamolekuliu junginių. Polimeru sintezè iš monomeru - lengvai aktyvinamų, dvigubujuc, trigubujų ryšių arba ne mažiau kaip dvi funkcines grupes turinčiuc, taip pat ciklinių junginių vadinama polimerizacija. Dažniausiai skiriami tokie polimerų sintezès būdai:

- grandininè polimerizacija:

$$
\mathrm{M}_{\mathrm{n}}^{*}+\mathrm{M} \rightarrow \mathrm{M}_{\mathrm{n}+1}^{*}
$$

čia $\mathrm{M}_{\mathrm{n}}^{*}$ - polimero grandinè, $\mathrm{M}$ - monomero molekulè.

- polieliminavimas (kondensacinė grandininè polimerizacija):

$$
\mathrm{M}_{\mathrm{n}}+\mathrm{M}_{\mathrm{m}} \rightarrow \mathrm{M}_{\mathrm{n}+\mathrm{m}},
$$

čia $\mathrm{M}_{\mathrm{m}}-$ monomerų reakcijos produktų molekulè.

- polikondensacija:

$$
\mathrm{M}_{\mathrm{n}}+\mathrm{M}_{\mathrm{m}} \rightarrow \mathrm{M}_{\mathrm{n}+\mathrm{m}}+\mathrm{S},
$$

čia $\mathrm{S}$ - šalutinis produktas.

- poliadicija (polimerinis jungimasis):

$$
\mathrm{M}_{\mathrm{n}}+\mathrm{M}_{\mathrm{m}} \rightarrow \mathrm{M}_{\mathrm{n}+1}+\mathrm{S} .
$$

Polimerizacijos proceso metu prie polimero grandinès aktyviojo centro $\mathrm{M}^{*}$ jungiasi monomero molekulès. Aktyvusis grandinès centras gali būti radikalas (radikalinè polimerizacija) arba jonas (joninè polimerizacija). Susidariusio polimero pagrindinès grandies elementinè sudètis tokia pati kaip ir monomero. 
Polieliminavimo metu prie polimero grandinès aktyviojo centro jungiasi tik monomero molekulès ir atskyla mažamolekuliai junginiai. Tokiu būdu susidaro daugelis biopolimerų (pvz., celiuliozè, baltymai (proteinas).

Polikondensacijos sintezès procese i grandines jungiasi monomerai ir visi reakcijos metu iš monomerų susidarę junginiai. Taip pat susidaro mažamolekuliai reakcijos produktai.

Poliadicijos procesas vyksta panašiai kaip ir polikondensacijos procesas, tačiau proceso metu nesusidaro mažamolekulių junginių.

Vieną polimerų sintezès būdą atskirti nuo kito galima pagal polimero vidutinio polimerizacijos laipsnio $P$ priklausomybę nuo monomero konversijos laipsnio $q$. Monomero konversijos laipsnis rodo, kuri dalis arba kiek procentų monomero sureagavo, t. y. susijungè i grandines.

Pagrindinè monomerų sintezès žaliava yra nafta ir gamtinès dujos. Polimeru sintezei taip pat naudojami monomerai, gauti perdirbant akmens anglis, polisacharidus (pvz., celiuliozę).

\subsection{Polimerų klasifikacija}

Polimerai gali būti klasifikuojami pagal kilmę, paskirti, naudojima, savybes. Pagal kilmę polimerai skirstomi taip: gamtiniai (pvz., celiuliozè, krakmolas, vilna, šilkas, oda, baltymai, natūralus kaučiukas), dirbtiniai (pvz., viskozè, kazeinas), sintetiniai.

Gamtiniai stambiamolekuliai junginiai išskiriami iš gamtinių medžiagu šalinant priemaišas ir mažamolekulius junginius (pvz., celiuliozè gaunama iš medienos, medvilnès pluošto atskyrus kitus komponentus).

Dirbtiniai polimerai gaunami cheminès reakcijos metu pakeičiant gamtinių stambiamolekulių junginių cheminę sudèti.

Sintetiniai polimerai - tai polimerai, gauti iš mažamolekulių junginiu - monomerų. Šiu polimeru yra daug, todèl jie gali būti dar skirstomi pagal anksčiau minètus sintezès būdus.

Pagal naudojimą polimerai klasifikuojami (1.3 pav.) taip: plastikai, elastomerai, pluoštai. 


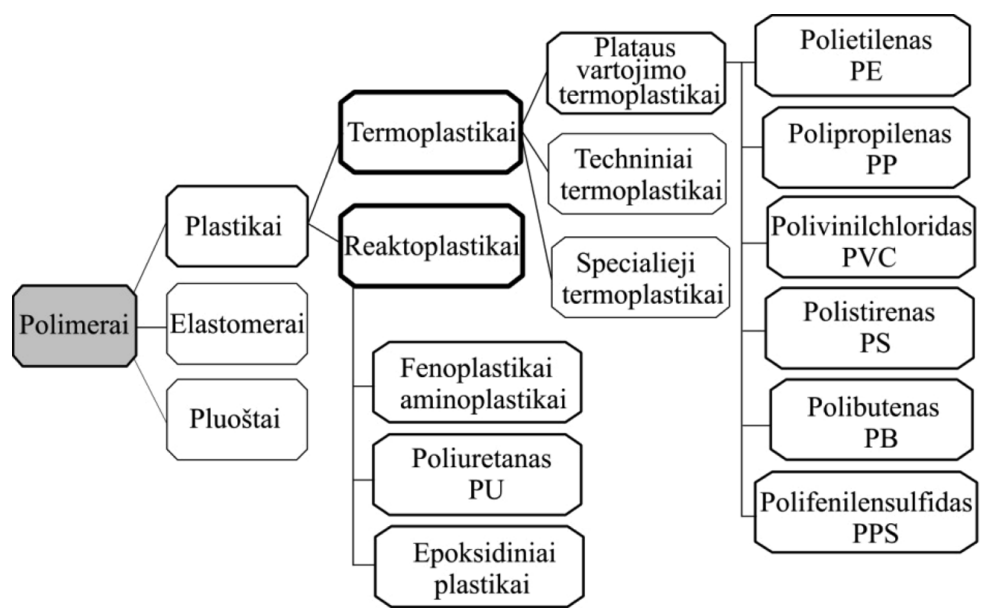

1.3 pav. Polimerų klasifikacija pagal naudojimą ir pagal savybių pokyčius šildant

Plastikai gaunami plastomerus sumaišius su priedais (užpildais, plastifikatoriais, dažikliais). Pagal savybiu pokyčius šildant jie dar skirstomi i termoplastinius ir reaktoplastinius polimerus (1.3 pav.).

Termoplastiniai polimerai - tai linijinès ir šakotosios struktūros polimerai. Termoplastiniai polimerai yra tokie, kurie minkšteja aukštesnèje temperatūroje ir kieteja ataušę. Tokie polimerai daug kartu iš kietų arba labai elastingų pasidaro klampiai takūs ir priešingai, nesikeičiant jų cheminei sudèčiai ir molekulinei struktūrai. Šios grupès polimerai tirpsta kai kuriuose organiniuose ir mineraliniuose tirpikliuose. Didžioji dalis termoplastikų sintetinami iš naftos perdirbimo produktų (dujų: eteno, propeno, buteno) ir iš jų dariniu (vinilchlorido, stireno) arba iš gamtinių dujų ir jų kondensato.

Tinklinès struktūros polimerai - reaktoplastikai (duroplastikai) deformuojasi mažai ir grižtamai, šildomi jie nekeičia formos ir būsenos. Jie netinka pakartotinai perdirbti ir nepereina i klampų būvi kaitinant. Tinklinès struktūros polimerai gaunami linijinius polimerus su specialiais priedais šildant (vulkanizacija), veikiant didelès energijos spinduliais (ultravioletiniais, rentgeno, infraraudonaisiais) arba naudojant specialias medžiagas - kietiklius. 
Elastomerai yra polimerai, sudaryti iš retai susiūtų makromolekulių. Jų grižtamoji deformacija eksploatavimo metu yra didelè (pvz., gumos).

Pluoštus sudaro pluošto ašies atžvilgiu orientuotos makromolekulès. Tokio polimero bandinio stipris šia kryptimi - didžiausias. Tai anizotropinès medžiagos. Eksploatacijos metu pluoštai deformuojasi mažai ir grižtamai, kai kurie jų šildomi gali elgtis kaip termoplastikai ir reaktoplastikai.

Plastikai taip pat gali būti skirstomi pagal rišamaja medžiaga, plastiku sudèti. Kaip rišamosios medžiagos gali būti sintetiniai polimerai, gauti polimerizacijos arba polikondensacijos būdu, taip pat chemiškai modifikuoti gamtiniai polimerai, bituminès dervos. Pagal sudètị plastikai skirstomi $\mathfrak{i}$ vienalytes paprastos struktūros medžiagas ir nevienalytes sudètingos struktūros medžiagas.

\subsubsection{Termoplastikai}

Termoplastikai kaitinami minkštèja, lydosi, o ataušinti vèl sukieteja ir atgauna pirmykštes savybes. Juos galima pakartotinai išlydyti ir perdirbti i gaminius. Formuojami jie susitraukia apie 1-3\%. Kadangi tarp polimero grandžiu yra tik nestiprus tarpmolekulinis ryšys, gaminiai yra elastingi, netrapūs. Gerų eksploatacinių savybiu termoplastikus galima pagaminti iš daugiau kaip penkių šimtu ivairios sudèties polimeru, tačiau pramonèje naudojama nuo 30 iki 40 polimerų. Pagal paskirti visus termoplastikus galima suskirstyti $i$ tokias grupes: plataus vartojimo, techninius, specialiuosius.

Plataus vartojimo termoplastikai tinkami ivvairiems gaminiams pakavimo plèvelèms, talpykloms, technikos detalèms, grindų ir izoliacinèms dangoms ir t. t. Techniniai termoplastikai sudaro 3-4\% visu gaminamų plastikų. Jie yra geresnių fizikinių-mechaninių savybiu negu plataus vartojimo termoplastikai. Specialieji termoplastikai - tai techniniai termoplastikai, kurių savybès ypač vertingos (pvz., atsparumas karščiui, tamprumo modulis ir pan.). Šie gaminiai yra labai brangūs ir jų gaminama tik apie $0,2 \%$ iš viso termoplastikų kiekio. 
Pirmieji plataus vartojimo sintetiniai termoplastikai (polistirenas, polivinilchloridas) pramoniniu būdu pradèti gaminti $1930 \mathrm{~m}$. Vokietijoje, chemijos koncerne „IG Farbenindustrie“. Iš termoplastikų plačiausiai naudojami polietilenas, polipropilenas, polivinilchloridas, polistirenas. Apie $70 \%$ naudojamų termoplastikų gamybos apimties sudaro polietileno ir polivinilchlorido gamyba.

Kai kurių termoplastikų fizikinės-mechaninės savybės pateiktos 1.2 lentelejje.

1.2 lentelè. Kai kurių termoplastikų fizikinès-mechaninès savybės

\begin{tabular}{l|c|c|c|c|c}
\hline \multirow{2}{*}{$\begin{array}{c}\text { Savybès ir matavi- } \\
\text { mo vienetai }\end{array}$} & \multicolumn{5}{|c|}{ Termoplastiku pavadinimas } \\
\cline { 2 - 6 } & $\begin{array}{c}\text { mažo } \\
\text { tankio }\end{array}$ & $\begin{array}{c}\text { didelio } \\
\text { tankio }\end{array}$ & PP & PVC & PS \\
\hline$\rho, \mathrm{kg} / \mathrm{m}^{3}$ & $915-925$ & $940-960$ & $900-930$ & 1350 & $1050-1080$ \\
\hline $\mathrm{DT},{ }^{\circ} \mathrm{C},(\mathrm{min} / \mathrm{max})$ & $-50 / 70$ & $-60 / 100$ & $-5 / 150$ & $-15 / 50$ & $-40 / 65$ \\
\hline $\mathrm{LT},{ }^{\circ} \mathrm{C}$ & 115 & 135 & 176 & - & - \\
\hline $\mathrm{E}, \mathrm{MPa}$ & 19 & 860 & 1400 & 3400 & 4100 \\
\hline $\mathrm{HB}$ & $14-25$ & $45-63$ & $80-90$ & $30-120$ & $140-150$ \\
\hline$\sigma, \mathrm{MPa}$ & 10 & 31 & 35 & 48 & 37 \\
\hline$\varepsilon, \%$ & 800 & 1200 & 700 & 60 & 0,9 \\
\hline
\end{tabular}

Pastaba: PE - polietilenas, PP - polipropilenas, PVC - polivinilchloridas, PS - polistirenas, $\rho$ - tankis, DT - darbo temperatūra, LT - lydymosi temperatūra, E - tamprumo modulis, $\mathrm{HB}$ - kietumas pagal Brineli, $\sigma$ - trūkio itempis, $\varepsilon$ - santykinis trūkstamasis pailgèjimas.

Termoplastiniams gaminiams formuoti dažniausiai taikomi šie būdai: liejimas slegiant, išcentrinis liejimas, ekstruzija, pūtimas, vakuuminis ir pneumatinis formavimas, štampavimas, presavimas, laisvasis liejimas.

Liejimu slegiant dažniausiai gaminamos sudètingos formos detalès. Suminkštinta iki klampiai takios būklès žaliava ipresuojama i pašildytą liejimo formą. Forma vėliau yra ataušinama vandeniu. Plastikui sukietejus preso forma atidaroma ir detalè išstumiama stūmok- 
liais. Šiuo formavimo būdu pagaminamas didžiausias įvairių dirbiniu kiekis. Formoje iš karto galima formuoti vieną ar keletą dirbiniu ar ju detaliu. Preso formos pavyzdys pateiktas 1.4 paveiksle.

Išcentrinio liejimo būdu išlydytas termoplastikas pilamas i karštą cilindrinę besisukančią formą, o išcentrinè jèga prispaudžia polimerą prie formos sienelių ir sutankina. Vèliau forma ataušinama ir sustabdoma, o ruošinys apdirbamas mechaniškai. Tokiu būdu dažniausiai gaminami storasieniai vamzdžiai, krumpliaračiai ir kt. termoplastiniai gaminiai.

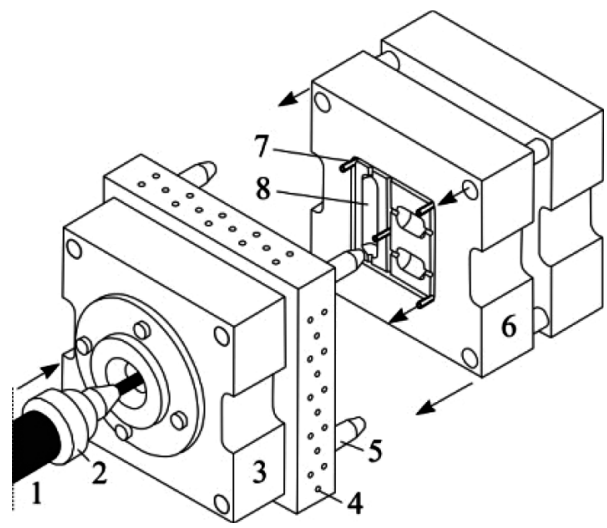

1.4 pav. Preso formos pavyzdys, kai formuojama liejimu slegiant:

1 - išlydyto termoplastinio polimero tiekimo galvute; 2 - ipurškimo

antgalis; 3 - nejudančioji preso formos dalis; 4 - temperatūros reguliavimo kanalai; 5 - formos kreiptuvai; 6 - judanti formos dalis;

7 - inžektorius; 8 - tuščia dirbinio formos ertmè

Ekstruzija - tai klampiai takios būklès termoplastiko išspaudimas pro tam tikros formos antgali. Šis gamybos procesas yra nenutrūkstamas. Ekstruderyje kaitinama žaliava suminkšteja ir besisukančiu sraigtiniu velenu ipresuojama i formavimo galvutę, kurioje plastikui suteikiama tam tikra forma. Išeinantis iš formos plastikas aušinamas ir jau išlaiko jam suteiktą formą (šis gamybos būdas plačiau aprašytas kituose skyriuose). Šiuo būdu gaminami įvairūs profiliai, strypai, vamzdžiai ir kt. gaminiai. 
Pūtimo būdu gaminami tuščiaviduriai dirbiniai: indai, talpyklos, plèvelès (aprašyta 2.3.1 skyriuje).

Vakuuminis ir pneumatinis formavimas. Šiems procesams naudojami ploni polimetilmetakrilato, polistireno, polivinilchlorido lakštai. Prieš formuojant lakštai ikaitinami iki didelio elastingumo būsenos. Formos kameroje sudaromas vakuumas, lakštas prispaudžiamas prie formos sieneliǔ, vèliau aušinamas. Esant storiems lakštams, vakuuminis būdas papildomas pneumatiniu. Formavimo vakuuminiu ir pneumatiniu presavimu principas pateiktas 1.5 paveiksle.
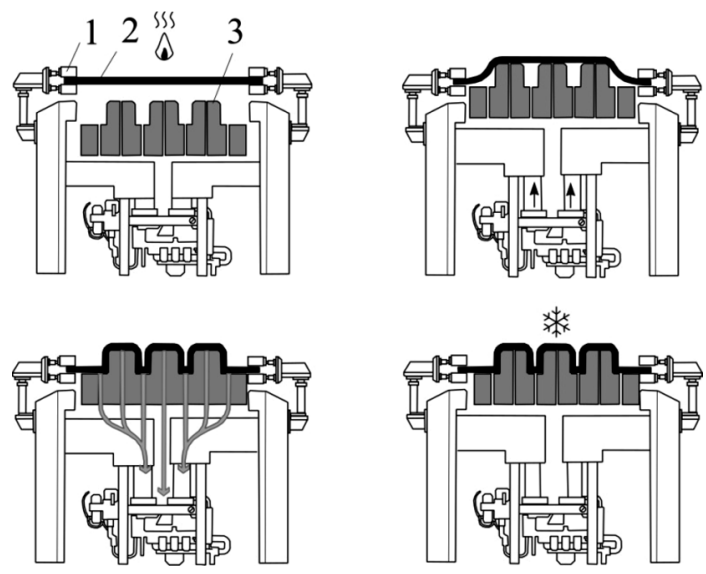

1.5 pav. Formavimo vakuuminiu ir pneumatiniu presavimu principas:

1 - lakšto laikiklis; 2 - lakštas; 3 - kaitinimo elementas

Štampavimo, presavimo būdu gaminami didelių matmenų plonasieniai dirbiniai. Žaliava pašildoma iki didelio elastingumo būsenos, vèliau po štampavimo, presavimo detalè yra aušinama.

Laisvojo liejimo būdu žaliava išlydoma, pilama i liejimo forma, kurioje stingsta nenaudojant papildomo slègio. Siekiant išvengti tuštumų, tankio skirtumų ir kitu defektų, liejimo forma gali būti tvirtinama ant vibracinio stalo arba gamybos metu liejimo formoje palaikomas vakuumas. Tokiu būdu gaminami dirbiniai iš polimetilmetakrilato, epoksidinių ir poliesterinių dervų. 


\subsubsection{Reaktoplastikai}

Reaktoplastiniai polimerai yra tokie, kuriuose ikaitinus ir ilgiau palaikius aukštesneje temperatūroje ivvyksta polimerizacijos reakcijos jie negrižtamai sukieteja, tampa stiprūs ir netirpūs. Pakartotinai kaitinami jie išlieka kieti iki cheminio suirimo temperatūros. Reaktoplastiniai polimerai sintetinami iš dideliais kiekiais gaminamų monomeru (karbamido, formaldehido, fenolio, anilino, glicerolio, melamino ir kt.). Reaktoplastikus sudaro termoreakcinès dervos (priklauso prie savaime kambario temperatūroje kietejjančiu polimeru), užpildai, plastifikatoriai, stabilizatoriai, kietikliai, dažalai, specialieji priedai. Reaktoplastikai yra atsparesni šilumai už termoplastikus. Kai kuriu reaktoplastikų fizikinès-mechaninès savybès pateiktos 1.3 lentelèje.

Statybiniams polimeriniams dirbiniams gaminti plačiai naudojamos termoreakcinès dervos: fenolo, anilio, karbamido, melamino aldehidinès dervos; epoksidinès, alkidinès dervos; silikonai ir kt.

Fenolio formaldehidinés dervos (PF) gaunamos polikondensacijos būdu iš fenolio ir formaldehido. Priklausomai nuo šių komponentu

1.3 lentelè. Kai kurių reaktoplastinių polimerų fizikinės-mechaninės savybès

\begin{tabular}{|c|c|c|c|c|}
\hline \multirow{3}{*}{$\begin{array}{c}\text { Žaliavos, } \\
\text { savybės } \\
\text { ir } \\
\text { matavimo } \\
\text { vienetai }\end{array}$} & \multicolumn{4}{|c|}{ Reaktoplastiniai polimerai } \\
\hline & $\begin{array}{c}\text { Poli- } \\
\text { kondensacinis }\end{array}$ & $\begin{array}{l}\text { Poli- } \\
\text { adicinis }\end{array}$ & $\begin{array}{l}\text { Poli- } \\
\text { adicinis }\end{array}$ & $\begin{array}{l}\text { Poli- } \\
\text { merizacinis }\end{array}$ \\
\hline & $\begin{array}{l}\text { rezoliai, novo- } \\
\text { lakai iš fenolio } \\
\text { ir } \\
\text { formaldehido }\end{array}$ & $\begin{array}{l}\text { daugia- } \\
\text { funkciai } \\
\text { izocianatai } \\
\text { ir polioliai }\end{array}$ & $\begin{array}{l}\text { epoksi- } \\
\text { dinès } \\
\text { dervos ir } \\
\text { kietikliai }\end{array}$ & $\begin{array}{l}\text { nesočiosios } \\
\text { poliesterinès } \\
\text { dervos ir } \\
\text { vinilmonomerai }\end{array}$ \\
\hline$\rho, \mathrm{kg} / \mathrm{m}^{3}$ & 1250 & 1050 & 1200 & 1270 \\
\hline $\mathrm{T},{ }^{\circ} \mathrm{C}$ & 130 & 91 & 170 & 155 \\
\hline $\mathrm{E}, \mathrm{MPa}$ & 2800 & 4400 & 2500 & 3400 \\
\hline$\sigma, \mathrm{MPa}$ & 65 & - & 70 & 70 \\
\hline$\varepsilon, \%$ & 1,8 & - & 6,0 & 2,0 \\
\hline
\end{tabular}

Pastaba: $\rho$ - tankis, $\mathrm{T}$ - formos išlaikymo temperatūra, $\mathrm{E}$ - tamprumo modulis, $\sigma$ - trūkio įtempis, $\varepsilon$ - santykinis trūkstamasis pailgejjimas 
santykio, skiriamos dvi formaldehidinių dervų atmainos - novalikinès ir rezolinès. Novalikinès dervos yra termoplastinès. Jos yra skaidrios, trapios, tirpsta spirite, acetone. Rezoninès dervos yra termoreakcinès, kaitinant jos tampa nelydžios ir netirpios. Rezolinių dervų termoreakcijos produktas - rezitas. Rezitas nesideformuoja veikiamas apkrovos, bet yra trapus. Rezolitų dervos naudojamos gaminant plastikines medžiagas presavimo būdu, sintetinius klijus.

Karbamido formaldehidinès dervos (UF) gaunamos polikondensacijos būdu iš karbamido ir formaldehido. Šios dervos yra bespalvès ir ore negelsta, tačiau laikui bėgant didejja jų trapumas.

Iš šių dervų gaminami sluoksniuotieji plastikai, putplasčiai, klijai, lakai, emaliniai dažai.

Melamino formaldehidinès dervos (MF) gaunamos iš melamino ir formaldehido. Šios dervos yra kietesnès, termiškai atsparesnès ir brangesnès nei karbamido formaldehidinès dervos. Šios dervos naudojamos analogiškai kaip ir karbamido formaldehidinès dervos.

Iš alkidiniu dervu ( $A F)$ labiausiai paplitusios yra gliftalinès dervos, gautos iš ftalio anhidrido ir glicerolio. Gliftalinès dervos yra termoreakcinès. Jos kietejja aukštesnèje temperatūroje lètai, todèl tokios dervos naudojamos kaip aukštos kokybès plèvelę sudarančios medžiagos ịvairiems lakams ir dažams gaminti. Alkidinių ir melamino formaldefidinių dervų mišiniu, įmaišius pigmentų, dažomi įvairūs metaliniai gaminiai, prietaisai, automobiliai. Vietoj glicerolio, naudojant pentaeritrita, gaunamos pentaftalinès dervos. Tokiomis emalèmis dažomi medienos gaminiai, namų apyvokos daiktai ir kt.

Epoksidines dervos (EP) gaunamos polimerizacijos būdu iš epichloridino ir difenilpropano. Jos polimerizuojamos kambario temperatūroje imaišius kietiklio. Sukietejjusios EP yra stiprios, netrapios, atsparios drègmei, šarmams, daugeliui neorganinių rūgščiu, tačiau jas ardo organinès rūgštys. Jos pasižymi gera adhezija su kitomis medžiagomis (metalais, plastikais, mediena, keramika). Epoksidinès dervos naudojamos kaip rišikliai stiklaplasčiui, jų pagrindu sudaromos lakų, emalinių ir miltelinių dažų kompozicijos. Kietedamos jos neišskiria pašalinių medžiagu, todèl susitraukia tik nuo 0,3 iki $1,0 \%$. 
Silikonai - tai silicio organinès dervos, kuriu pagrindinè grandinè sudaryta iš silicio ir deguonies atomų. Aukštesnëje temperatūroje silikoninès dervos yra stabilesnès už kitus polimerus, jų mechaninès savybès beveik nesikeičia iki $300^{\circ} \mathrm{C}$ temperatūros. Silikonai gali būti skysti (naudojami kaip hidrofobiniai tirpalai), nekietejantys elastomerai (silikoninis kaučiukas) ir kieti (naudojami kaip atsparios aukštesnei temperatūrai ir drègmei konstrukcinès medžiagos).

Pagrindinis reaktoplastikų formavimo į dirbinius būdas yra priesavimas. Svarbiausi presavimo proceso parametrai yra presavimo temperatūra, slègis ir gaminiu išlaikymo laikas slegiant. Kaitinami reaktoplastikai išsilydo, sutankejja, užpildo formavimo kameros tūri, dar toliau kaitinami - negrižtamai sukietèja. Reaktoplastiniams gaminiams formuoti dažniausiai taikomi šie gamybos būdai: tiesioginis presavimas, liejamasis formavimas, formavimas sluoksniais.

Tiesioginis presavimas gali būti atliekamas atvirose arba uždarose presavimo formose, kuriose ikaitintas ruošinys slegiamas. Atviros presavimo formos dažniausiai naudojamos nesudetingos formos detalèms iš gumos arba sluoksniuotiesiems plastikams presuoti. Uždaros presavimo formos naudojamos plonasieniams gaminiams iš pluoštinių arba sluoksniuotujų reaktoplastikų presuoti.

Liejamasis formavimas naudojamas sudetingos formos ir didelio tikslumo gaminiams su plonomis sienelèmis bei metaline ar kitokia armatūra lieti.

Formuojant sluoksniais dažniausiai gaminami lakštiniai kompozitai - tekstolitas, stiklo tekstolitas ir kt. Gamybos metu tarp kaitinamu presavimo plokščiu klojama polimero lydiniu įmirkyta pluoštinè medžiaga.

\subsection{Plastikų priedai}

Gaminant plastikus, be polimeru̧, dar naudojami priedai, tai: užpildai, plastifikatoriai, stabilizatoriai, kietikliai, dažalai, specialūs priedai.

Užpildai - tai medžiagos, kurių dedama i plastikus norint pakeisti savybes arba sutaupyti tam tikrą polimerinès medžiagos kieki. 
Užpildai gali sudaryti 7-70 \% plastiko masès. Jie padidina stipruma, kietumą, sumažina reaktoplastikų susitraukimą formuojant, gali pakeisti kai kurias kitas savybes (pvz., atsparumą kaitrai). Užpildai gali būti organiniai (medienos miltai, celiuliozè, popierius, medvilninis audinys ir kt.) ir neorganiniai (grafitas, stiklo pluoštas, žèrutis ir kt.). Pagal struktūrą užpildai skirstomi i dispersinius, pluoštinius ir sluoksniuotuosius. Dispersiniai užpildai, sumaišyti su polimerais, sudaro izotropinę tankią, kietą masę, padidina polimero standumą. Dispersiniai užpildai susideda iš vieno ar kelių labai smulkių komponentu, išsidèsčiusių matricoje. Pluoštiniai užpildai - tai dažniausiai didelio stiprumo stiklo, anglies, boro pluoštai, metalinès vielelès. Šie užpildai padidina mechanini stipruma, smūgini tąsuma, tačiau kadangi plastikų savybės ịvairiomis kryptimis yra nevienodos, dirbiniai gaunami anizotropiniai. Sluoksniuotieji užpildai susideda iš dviejų ar daugiau sluoksnių. Sluoksniai gali būti sudaryti iš medvilnès, anglies pluošto audinio, popieriaus ir kt.

Plastifikatoriu paskirtis - sumažinti polimero stiklejjimo temperatūra, trapuma, padidinti minkštuma, elastingumą. Plastifikatoriai turi būti mažai lakūs, turèti aukštą virimo temperatūrą, būti netoksiniai, chemiškai patvarūs. I mišini jų dedama nuo procento dalių iki dešimčių procentų mišinio masès. Dažniausiai naudojami plastifikatoriai - tai aliejiniai klampūs organiniai skysčiai arba vaško tipo medžiagos (stearinas, ricina, dibutilftalatas it kt.)

Stabilizatoriai - medžiagos, kurios saugo plastikus nuo senèjimo veikiant aplinkai, nes, veikiamos šilumos, oro deguonies ir šviesos, makromolekulès trūkinèja ị dalis, susidaro papildomos skersinès jungtys, o tai blogina plastikų savybes. Dažniausiai stabilizatoriai sudaro $0,14-3 \%$ plastiko masès. Naudojami aromatiniai aminai, fenolio dariniai, dispersiniai metalų milteliai.

Kietikliai - tai medžiagos, kurių dedama siekiant padaryti reaktoplastikus nelydžius ir netirpius, kai formuojami gaminiai. Epoksidiniuose ir poliesteriniuose polimeruose kaip kietikliai naudojami daugiafunkciai junginiai (glikoliai, tiaminai, izocianatai). Jie daly- 
vauja kondensacijos reakcijose ir naudojamos kaip medžiagos, kurios skatina polimerizacijos procesą (naftenatai, peroksidai).

Dažalai - tai smulkiai sumaltos spalvotos mineralinès medžiagos (pigmentai), taip pat organiniai dažikliai, išliekantys patvarūs formavimo temperatūroje ir suteikiantys plastikams reikalingą spalvą.

Specialieji priedai gali būti labai ịvairios paskirties: tepimo medžiagos - didina plastikų elastingumą ir takumą, lengvina formavimą ir gaminio išèmimą iš formos; antipirenai - mažina polimerų degumą; antistatikai - mažina statini įsielektrinima; antimikrobiniai priedai - mažina biologini pažeidžiamumą ir kt. (stearinas, oleino rūgštis ir kt.); porodariai - medžiagos, kurios kaitinamos virsta dujomis ir sudaro poras. Porodarių dedama i polimerus, kai norima gauti putpalsčius ar sumažinti plastikų tanki. 


\section{TERMOPLASTIKAI}

\subsection{Polistireninis putplastis (PS)}

Polistireninis putplastis gali būti dviejų tipų - EPS ir XPS. Polistireninis putplastis (EPS - tarptautinis pavadinimas, angl. expanded polystyrene) yra standi poringa medžiaga, pagaminta sulydant išpūsto polistireno arba vieno iš jo kopolimeru granules, kuriu uždaros poros užpildytos oru (2.1 pav.). Polistireninio putplasčio oficialus pavadinimas buvo iteisintas $2003 \mathrm{~m}$. isigaliojus Europos Sajungos standartui LST EN 13163:2003 „Statybiniai termoizoliaciniai gaminiai. Gamykliniai polistireninio putplasčio (EPS) gaminiai“.

a

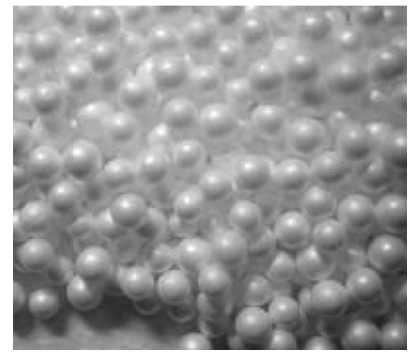

b

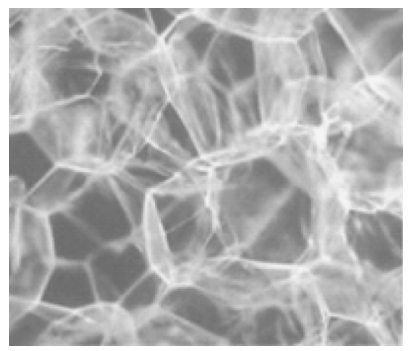

2.1 pav. Polistireninis putplastis: a - bendras granulių vaizdas; $\mathrm{b}$ - granulès vidinès erdvès vaizdas

Polistireninis putplastis (XPS angl. extruded polystyrene foam) - tai kieta izoliacinè poroplastinè medžiaga, pagaminta iš išpūsto uždaros porų struktūros ekstrudinio polistireno arba iš vieno jo kopolimerų turinčių dangą arba be jos (2.2 pav.). XPS savybès turi atitikti LST EN 13164:2004 „Statybiniai termoizoliaciniai gaminiai. Gamykliniai ekstruzinio polistireninio putplasčio (XPS) gaminiai" standarto reikalavimus.

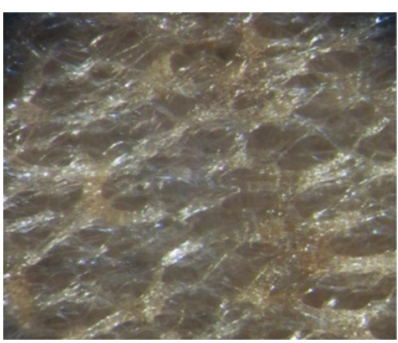

2.2 pav. XPS polistireninis putplastis (vidinès erdvès vaizdas, padidinta 56 kartus) 
Polistireninis putplastis naudojamas visų pastato atitvarinių konstrukcijų (rūsio, išorinių sienų, grindų, stogo) šilumai izoliuoti. Polistirenini putplasti sudaro $98 \%$ oro, uždaryto ị nedidelio skersmens akeles, ir $2 \%$ polistireno, sudarančio šių akelių sieneles.

Šiuo metu pasaulyje iš polistireninio putplasčio, kuris naudojamas statyboje ir buityje, gaminamos ivvairios paskirties plokštès, blokeliai ir blokai. Tačiau nagrinèjant polistireninio putplasčio perdirbimą galima teigti, kad produktai, pagaminti iš šios medžiagos, nėra perdirbami (yra nedidelių išimčių, kai polistireninio putplasčio trupiniai naudojami lengvajam betonui ar skiediniui gaminti, tačiau tai tik nedideli atlieku kiekiai). Perdirbimo procesą labiausiai stabdo tai, kad trūksta paskatų investuoti i perdirbimo technologijas. Polistireninio putplasčio laužas galètų būti itrauktas i tokių produktų, kaip EPS plokštès, gamybą. Tuo labiau, kad visos atliekos, susidarančios gamybos metu, yra grąžinamos ị technologini ciklą.

Kiekviena plastikų grupè gali būti identifikuojama pagal plastiko identifikavimo kodą (PIC, ang. Plastic Indentification Code). I ši kodą ieina skaičių arba raidžių santrumpa. PIC sudaro trys kreivalinijinès rodyklès, išdèstytos pagal laikrodžio rodyklę. Šis produktų simbolis nurodo, ar plastikas gali būti perdirbtas i naujus produktus ir koks tai yra plastikas. PIC buvo sukurtas tam, kad perdirbimo imonès lengviau atskirtų skirtingų rūšių plastiką.

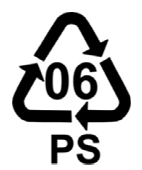

2.3 pav. Polistireno indentifikavimo kodas
Kai kuriose šalyse ar regionuose plastikinių gaminių gamintojai privalo naudoti PIC etiketes, kiti gali savanoriškai ženklinti savo produktus, jei nekeliama jokiu reikalavimu. Polistireno indentifikavimo kodas pateiktas 2.3 paveiksle.

\subsubsection{Polistireninio putplasčio žaliavos}

Polistireninis putplastis gaminamas iš polistireno, kuris gaminamas iš naftos perdirbimo produktų - stireno $\left(\mathrm{C}_{8} \mathrm{H}_{8}\right)$, o pastarasis sintetinamas iš benzeno ir eteno. Stirenas gaunamas prapučiant eteną 
esant slegiui per skystą benzeną ir, dalyvaujant aliuminio chloridui, vyksta tokia reakcija:

$$
\mathrm{C}_{6} \mathrm{H}_{6}+\mathrm{CH}_{2}=\mathrm{CH}_{2} \frac{\mathrm{AlCl}_{3}}{90{ }^{\circ} \mathrm{C}} \mathrm{C}_{6} \mathrm{H}_{5}-\mathrm{CH}_{2}-\mathrm{CH}_{3} \text {. }
$$

Susidaręs etilbenzenas, dalyvaujant katalizatoriui, dehidratuojamas aukštoje temperatūroje, kol susidaro stirenas:

$$
\mathrm{CH}\left(\mathrm{C}_{6} \mathrm{H}_{5}\right)=\mathrm{CH}_{2} \text {. }
$$

Stirenas ir pentanas yra angliavandeniliai. Polimerizacijos metu stireno molekulès jungiasi viena su kita i grandines. Polimerizacijoje dalyvaujant pentanui $\left(\mathrm{C}_{5} \mathrm{H}_{12}\right)$, gaunama plètriojo polistireno medžiaga:

$$
\mathrm{nCH}\left(\mathrm{C}_{6} \mathrm{H}_{5}\right)=\mathrm{CH}_{2} \rightarrow\left[\mathrm{CH}\left(\mathrm{C}_{6} \mathrm{H}_{5}\right)-\mathrm{CH}_{2}\right]_{\mathrm{n}}
$$

arba

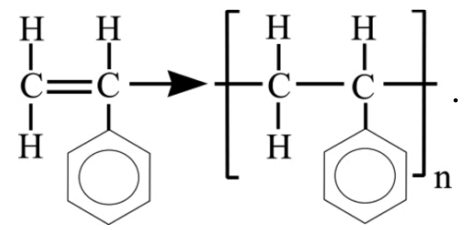

Stireno polimerizacijai sužadinti pakanka šiluminès energijos. Stireno termine polimerizacija kondensuotame monomere pradedama nuolatinio veikimo maišymo reaktoriuje ir baigiama bokštiniame reaktoriuje (2.4 pav.).

Iš talpyklos skystas stirenas tiekiamas i intensyviai aušinamą maišymo reaktorių, kuriame vyksta pirmoji polimerizacijos stadija. Maišymo reaktoriuje temperatūra siekia $80-82{ }^{\circ} \mathrm{C}$, polimerizuojama tol, kol $40 \%$ monomero virsta polimeru. Toliau polistireno tirpalas patenka i bokštini reaktorių, kuriame vyksta antroji polimerizacijos stadija. Čia temperatūra pakeliama nuo 110 iki $200{ }^{\circ} \mathrm{C}$ ir polimerizuojamas visas likęs monomeras (konversijos laipsnis - $100 \%$ ). I polimerizacijos bokštinio reaktoriaus apačią po 28 valandų patekęs polistireno lydalas sliekiniu transporteriu išspaudžiamas ant juostinio 
transporterio, aušinamas ir smulkinamas granuliatoriumi. Terminès polimerizacijos būdu gautas polistirenas neturi priemaišų, yra skaidrus ir didelès molekulinès masès $(\sim 0,5 \mathrm{mln}$.).

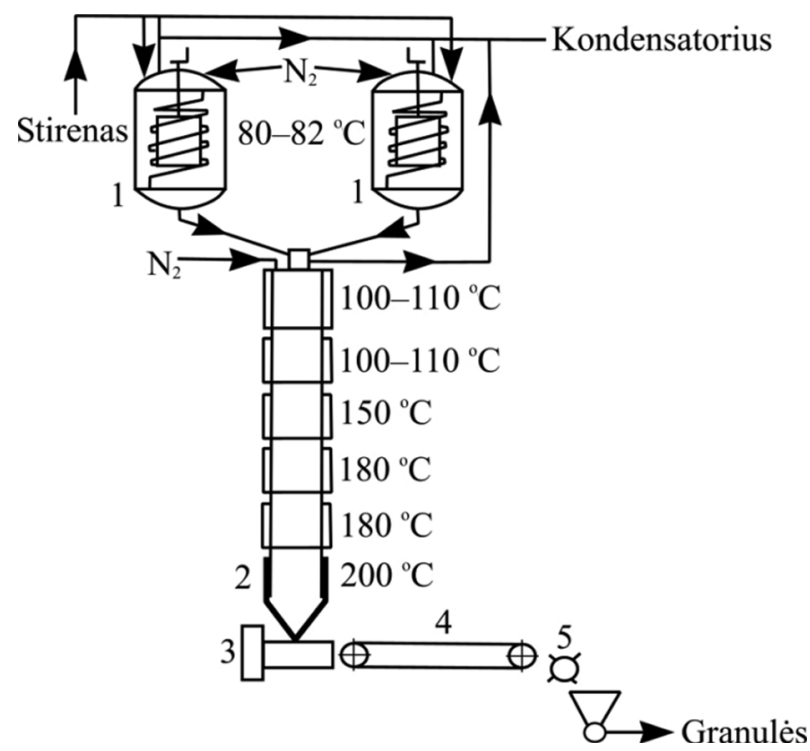

2.4 pav. Nuolatinio veikimo polistireno sintezès įrenginys:

1 - maišymo reaktorius; 2 - bokštinis reaktorius;

3 - sliekinis transporteris; 4 - juostinis transporteris;

5 - granuliatorius

Polistirenas yra kietas, skaidrus, amorfinis, termoplastinis polimeras. Tempiamos amorfinio polistireno molekulès iš dalies orientuojamos. Toks polistirenas yra standesnis, stipresnis, atsparesnis smūgiams. Aukštesnèje temperatūroje ir šviesoje polistirenas oksiduojasi, o $300{ }^{\circ} \mathrm{C}$ temperatūroje-depolimerizuojasi. Polistirenas tirpsta benzene, benzine, kai kuriuose chlorintuose angliavandeniliuose. Ore veikiamas ultravioletinès spinduliuotės jis pamažu sensta, oksiduojasi, geltonuoja, pradeda pleišèti. Polistirenas atsparus vandeniui ir tepalams, žemoje temperatūroje - koncentruotoms rūgštims (išskyrus koncentruotą azoto rūgšti) ir šarmams. 
Pentanas, naudojamas polistireniniam putplasčiui gaminti kaip plètiklis, yra sotusis angliavandenis, i kurio sudetti ieina metanas ir propanas. Pentanas yra bespalvis, labai lakus, vandenyje beveik netirpus skystis, kurio virimo temperatūra yra apie $35^{\circ} \mathrm{C}$. Pentanas yra sudedamoji naftos dalis, tačiau jis susidaro ir žmogaus bei gyvūnu organizmuose - vykstant natūraliems biocheminiams procesams patenka i atmosferą iškvepiant orą. Gaminant polistirenini putplasti, garo pavidalo pentanas patenka i atmosfera, kur greitai suardomas ir virsta anglies dioksidu ir vandeniu.

Polistireniniam putplasčiui gaminti dažnai naudojami antipirenai - degumą slopinantys priedai. Dažniausiai kaip degumą slopinantis priedas naudojamas heksabromciklododekanas (HBCD). Polimerizacijos metu, kai stirolo molekulès jungiasi viena su kita $i$ grandines, iterpiamas antipirenas - vandenyje netirpi, atspari hidrolizei medžiaga. EPS polistireniniam putplasčiui gaminti naudojamos skaidrios sferinès $0,2-0,3 \mathrm{~mm}$ dydžio plètriojo polistireno granulès.

\subsubsection{EPS polistireninio putplasčio gamyba}

Statyboje dažniausiai naudojamos polistireninio plutplasčio plokštès ar blokai.

Polistireninio putplasčio blokas - standus izoliacinis gaminys, kurio pjūvis paprastai yra stačiakampio formos, o storis nereikšmingai mažesnis už ploti. Blokai gali būti apdailinti arba neapdailinti.

Polistireninio putplasčio plokštè - standus izoliacinis gaminys (supjaustytas atskirai arba suformuotas nepertraukiamuoju juostiniu būdu), kurio pjūvis yra stačiakampio formos, o storis gerokai mažesnis nei kiti matmenys. Plokštės gali būti vienodo storio arba plonèjančios. Plokštès kraštai gali būti ịvairių formų (pvz., nupjauti statmenai, laiptuoti, su grioveliais ir pan.).

EPS polistireno granulès gaminamos iš polistireninio pusfabrikačio, kuriame yra dujodario izopentano. Granulès išsipučia $90-120^{\circ} \mathrm{C}$ temperatūroje. Galimi šie gamybos būdai: veikiant žaliavą karštu vandeniu, garais, karštu oru arba aukštojo dažnio elektros srove. 
EPS polistireninio putplasčio plokštès gamykloje gaminamos vienos stadijos ir dviejų stadijų būdu (dažniausiai). Šiuolaikiniai standartai reikalauja, kad gaminiai būtų tikslių matmenų, vienodų šilumos izoliacinių savybių visame plokštès tūryje ir t. t. Todèl dažniausiai taikomas dviejų stadijų gamybos būdas, kai šilumnešis yra vandens garai.

Gaminių gamyba iš polistireno granulių nusakoma tuo, kad polistirenas, įkaitęs daugiau kaip $80^{\circ} \mathrm{C}$, iš kietosios būsenos pereina i elastingaja, o izopentanas - dujodaris, teinantis i polistireno granuliu sudèti, kai temperatūra pakyla daugiau kaip $28^{\circ} \mathrm{C}$, pereina iš skystosios būsenos ì dujinę. Veikiant dujų slègiui suminkštintų polistireno granulių tūris padidejja. Granuliu tūrio didèjimas priklauso nuo temperatūros. Maksimalus granulių tūris tampa esant $90-100{ }^{\circ} \mathrm{C}$ temperatūrai.

Polistireninio putplasčio (EPS) gamybos procesą dažniausiai sudaro kelios stadijos: pradinis pūtimas; tarpinis išlaikymas; galutinis pūtimas; pjaustymas.

Principinè polistireninio putplasčio (EPS) gamybos schema pavaizduota 2.5 paveiksle. Polistireninio putplasčio (EPS) granulès beriamos i i išpūtimo irengini, kuriame jos karštu maždaug $95^{\circ} \mathrm{C}$ temperatūros garu išpučiamos. Veikiamos karšto garo, granulių sienelès suminkštèja. Pentanas, esantis granulèse, užverda. Dèl jo garų, taip pat iš dalies ir dèl ịsiskverbiančių vandens garu granulès išsiplečia 35-50 kartų ir virsta dalelèmis su didele vidine poringa erdve.

Pirminis granulių išpūtimas atliekamas tam, kad gauto gaminio tankis būtų kuo mažesnis ir pūtimo laikas baigiamojoje gamybos stadijoje sutrumpètų.

Pirminis išpūtimas vyksta naudojant garą sraigtiniuose arba nepertraukiamojo veikimo būgniniuose aparatuose. Sraigtinis aparatas susideda iš sraigtinio konvejerio, apiplaunamo garu, dozatoriaus su bunkeriu, reduktoriaus ir elektros variklio. Suspensinis polistirenas tiekiamas i bunkeri per dozatoriuc, esanti ant sraigtinio konvejerio, kuriuo juda iškrovimo angos link. Konvejeryje taip pat juda per anga korpuse tiekiamas garas, kurio slègis yra apie $0,1 \mathrm{MPa}$. Tiekiamas 


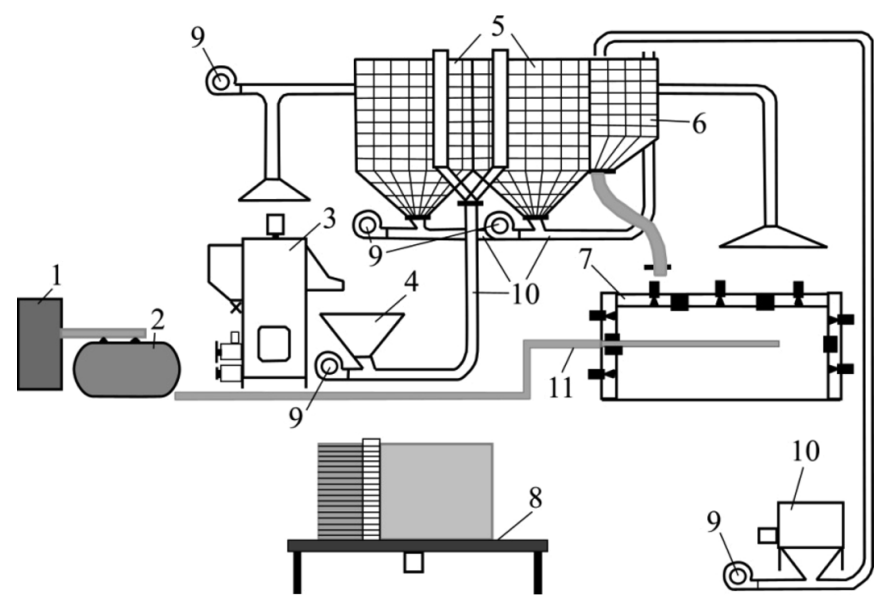

2.5 pav. Principinė polistireninio putplasčio (EPS) gamybos schema: 1 - garu generatorius; 2 - garų talpykla; 3 - pirminis granulių išpūtimo irenginys; 4 - prièmimo bunkeris su džiovintuvu; 5 - išlaikymo bunkeris;

6 - bunkeris; 7 - blokų formavimo įrenginys; 8 - pjaustymo įrenginys;

9 - ventiliatoriai; 10 - pneumatinis transportas; 11 - vamzdynas garams transportuoti

garas ikaitina polistireną iki $95-102{ }^{\circ} \mathrm{C}$ temperatūros. Išpūtimo laikas siekia 1-2 min. Sraigtinio aparato našumas yra iki $2,5 \mathrm{~m}^{3} / \mathrm{h}$, priklausomai nuo polistireno savybių. Tokiu pat principu polistirenas išpučiamas ir naudojant besisukantị būgnini aparatą. Tačiau šio aparato našumas yra apie du kartus didesnis. I aparatą tiekiamas garas yra 0,07-0,09 MPa slègio, o jo temperatūra - 90-97 ${ }^{\circ} \mathrm{C}$. Garas ị būgnini aparatą tiekiamas 3-6 min. Jeigu gamybos apimtys nedidelès, naudojami periodinio veikimo išpūtimo aparatai. Tai gali būti vonios su vandeniu. Vanduo turi būti pakaitintas iki $95-98{ }^{\circ} \mathrm{C}$ temperatūros.

Po pradinio išpūtimo polistireninio putplasčio granulès transportuojamos i tarpinio išlaikymo bunkerius. Tarpinio išlaikymo metu iš granulių pasišalina dalis plètiklio (pentano), kuri pakeičia oras. Tai daro granules mechaniškai stabilesnes. Tarpinis išlaikymas gali trukti 4-12 val. Išlaikymo laikas priklauso nuo granulių dydžio, piltinio tankio, likutinès drègmès. Išlaikytos išpūstos granulès pilamos i aliuminini arba nerūdijančiojo plieno blokų formą, kurioje per atitin- 
kamas angas, veikiamos karšto garo, jos dar labiau išsipučia ir susilydo i polistireninio putplasčio bloką. Vèliau blokai yra supjaustomi pjaustymo irenginyje. Toks gamybos būdas vadinamas periodiniu. Formos gali būti stacionarios arba perstumiamos. Gaminant polistirenini putplasti galimas ir toks gamybos etapas, kai formos su užpiltu polistirenu surenkamos i paketus ir siunčiamos i autoklava, kuriame tiekiamas garas ir gaminiai ikaitinami iki $95-105^{\circ} \mathrm{C}$ temperatūros. Baigiamasis išpūtimo procesas vyksta $1-2$ min. Po išpūtimo gaminiai aušinami $10 \mathrm{~min}$.

Nenutrūkstamasis formavimo būdas taikomas įvairiuose ịrenginiuose: konvejerinèse linijose; paketiniuose formuotuvuose; karuselinèse mašinose. Nenutrūkstamojo veikimo polistireninio putplasčio gaminių gamybos technologija susideda iš tų pačių operacijų kaip ir periodinio gaminiu formavimo metu. Polistireninis putplastis gaunamas ištisinėmis juostomis, kurių storis 50-100 mm, arba blokais, kurių tūris $0,3 \mathrm{~m}^{3}$. Polistireninio putplasčio nenutrūstamojo formavimo mašiną sudaro horizontalus konvejeris, kuris susideda iš trijų zonų:

1. pakrovimo zonos, kurioje polistirenas veikiamas 105$120^{\circ} \mathrm{C}$ temperatūros garo ir $0,035 \mathrm{MPa}$ slègio;

2. formavimo zonos,

3. aušinimo zonos, kurioje aušinama oru iki $40{ }^{\circ} \mathrm{C}$ temperatūros. Vèliau plokštès išilgai ir skersai supjaustomos pjūklais.

Paketų formuotuvas veikia pulsuojančiame ruože. Paketas susideda iš 24 formų, judančių vertikalioje šachtoje iš apačios i viršų. Forma užpildoma iš anksto išpūstomis granulèmis. Toliau išpučiama perkaitintuoju garu, kurio temperatūra $103-112^{\circ} \mathrm{C}$. Išpūtimo procesas trunka 1 min. Paskui formos juda i viršų, ten gaminiai patenka i aušinimo zoną. Aušinimo trukmè - 20 min.

Ką tik pagamintas polistireninis putplastis kurị laiką išskiria plètikli (pentana) ir stireno likučius ir per pirmąsias 24 valandas aušdamas, priklausomai nuo gamybos sąlygu ir tankio, susitraukia. Susitraukimas gali siekti iki $0,3-0,5 \%$. Todèl pagamintas polistireninis putplastis pirmąsias keletą dienų išlaikomas gamykloje. 
Šiuo metu daugiausia polistireninio putplasčio gaminama iš Anglijos ir Vokietijos firmų žaliavų „Styrocell“" ir „Styropor“. Lietuvoje gaminamos skirtingo tankio polistireninio putplasčio plokštés. Skirtingas tankis pasiekiamas naudojant atitinkamos frakcijos polistireno pusfabrikati (biseri). Atitinkamas pusfabrikačio dydis užtikrina tam tikro skersmens išpūstą polistireno granulę. Po pirminio pūtimo granulių dydis svyruoja nuo 1,25 iki $10 \mathrm{~mm}$. Pavyzdžiui: $35 \mathrm{~kg} / \mathrm{m}^{3}$ tankio polistireninio putplasčio plokštėms gaminti naudojamos išpūsto polistireno iki $2,5 \mathrm{~mm}$ skersmens granulès, $25 \mathrm{~kg} / \mathrm{m}^{3}$ tankio - iki $7 \mathrm{~mm}$ skersmens granulès ir $15 \mathrm{~kg} / \mathrm{m}^{3}$ tankio - iki $10 \mathrm{~mm}$ skersmens granulès. Polistireninio putplasčio gaminimo energijos sąnaudos yra pakankamai mažos, palyginti su kitomis termoizoliacinèmis medžiagomis.

\subsubsection{EPS polistireninio putplasčio klasifikavimas ir savybès}

Polistireninio putplasčio (EPS) gaminiai skirstomi į tipus pagal stiprumines savybes, kaip parodyta 2.1 lenteleje. Kiekvienas tipas, išskyrus EPS S (naudojamas ten, kur nèra apkrovos), turi vienu metu atitikti dvi salygas. Jei polistireninis putplastis atitinka ir akustinius reikalavimus, prie tipo pavadinimo pridedama raide $T$.

Fizikinès-mechaninès savybès. Polistireniniam putplasčiui būdingas gniuždymo ittempis, lenkimo stipris, statmenas paviršiui tempiamasis stipris ir kt. Polistireninio putplasčio gniuždymo įtempis dažniausiai priklauso nuo tankio. Polistireninis putplastis yra labai lengva medžiaga. Jo tankis $-9-40 \mathrm{~kg} / \mathrm{m}^{3}$. Gniuždymo stipris svarbus gaminiams, kurie naudojami sutapdintiesiems stogams ir grindims izoliuoti. Lenkimo stiprio reikalavimai dažniausiai siejami su gaminių transportavimu ir montavimu. Statmenas paviršiui tempiamasis stipris nustatomas polistireninio putplasčio gaminiams, kurie naudojami išorinèms sudètinèms termoizoliacinèms sistemoms izoliuoti. Statmeno paviršiui tempiamojo stiprio ribiniai lygiai pateikti 2.2 lentelèje. 
2.1 lentelè. Polistireninio putplasčio klasifikavimas

\begin{tabular}{l|c|c}
\hline \multicolumn{1}{c|}{ Tipas } & $\begin{array}{c}\text { Gniuždymo itempis, kai gaminys } \\
\text { deformuojamas } 10 \%, \mathrm{kPa}\end{array}$ & Lenkimo stipris, $\mathrm{kPa}$ \\
\hline EPS S & - & 50 \\
\hline EPS 30 & 30 & 50 \\
\hline EPS 50 & 50 & 75 \\
\hline EPS 60 & 60 & 100 \\
\hline EPS 70 & 70 & 115 \\
\hline EPS 80 & 80 & 125 \\
\hline EPS 90 & 90 & 135 \\
\hline EPS 100 & 100 & 150 \\
\hline EPS 120 & 120 & 170 \\
\hline EPS 150 & 150 & 200 \\
\hline EPS 200 & 200 & 250 \\
\hline EPS 250 & 250 & 350 \\
\hline EPS 300 & 300 & 450 \\
\hline EPS 350 & 350 & 525 \\
\hline EPS 400 & 400 & 600 \\
\hline EPS 500 & 500 & 750 \\
\hline
\end{tabular}

2.2 lentelè. Statmeno paviršiui tempiamojo stiprio ribiniai lygiai

\begin{tabular}{c|c|c|c|c|c|c|c}
\hline Ribinis lygis & TR & TR & TR & TR & TR & TR & TR \\
\hline $\begin{array}{c}\text { Reikalaujamas } \\
\text { lygis, } \mathrm{kPa}\end{array}$ & $\geq 20$ & 50 & 80 & 100 & 150 & 200 & 400 \\
\hline
\end{tabular}

Šilumos laidumas. Polistirenini putplastị sudaro uždarose porose esantis oras ir polistirenas, sudarantis porų karkasą. Nejudantis oras yra blogas šilumos laidininkas, todèl jis užtikrina geras polistireninio putplasčio termoizoliacines savybes. Apytikrè polistireninio putplasčio deklaruojamojo šilumos laidumo koeficiento priklausomybė nuo medžiagos tipo pateikta 2.3 lentelèje.

Polistireninio putplasčio gaminiams būdingas 0,030 $0,045 \mathrm{~W} /(\mathrm{m} \cdot \mathrm{K})$ deklaruojamasis šilumos laidumo koeficientas. 
2.3 lentelè. Apytikrė polistireninio putplasčio deklaruojamojo šilumos laidumo koeficiento priklausomybè nuo medžiagos tipo $\left(\lambda_{d}-\right.$ šilumos laidumo koeficientas, $\mathrm{W} /(\mathrm{m} \cdot \mathrm{K})$

\begin{tabular}{c|c|c|c|c|c|c}
\hline Tipas & EPS 50 & EPS 70 & EPS 80 & EPS 100 & EPS 150 & EPS 200 \\
\hline$\lambda_{d}$ & 0,043 & 0,039 & 0,038 & 0,035 & 0,034 & 0,033 \\
\hline
\end{tabular}

Matmenu kitimas. Polistireninio putplasčio matmenys kinta dèl temperatūros poveikio, susitraukties ir mechaninès apkrovos. Polistireninio putplasčio terminio plètimosi koeficientas yra 0,05$0,07 \mathrm{~mm} / \mathrm{m}$, gaminio temperatūrai pakilus $1^{\circ} \mathrm{C}$. Š is terminis polistireninio putplasčio plètimasis yra grižtamasis reiškinys. Polistireninio putplasčio gaminys, kurio ilgis $0,4 \mathrm{~m}$, atšaldytas nuo $+20 \mathrm{iki}-20{ }^{\circ} \mathrm{C}$ temperatūros, susitraukia $1 \mathrm{~mm}$.

Polistireninio putplasčio susitrauktis skirstoma $i$ ankstyvają ir vėlyvaja. Susitrauktis sukelia negrižtamus polistireninio putplasčio matmenų pokyčius. Ankstyvoji polistireninio putplasčio susitrauktis - tai gaminio matmenų pokytis, vykstantis per pirmąsias $24 \mathrm{~h}$. Ji lygi $0,3-0,5 \%$. Vèliau vykstantis gaminio matmenų sumažejjimas vadinamas vèlyvaja susitrauktimi. Vèlyvoji susitrauktis sparčiausiai vyksta per pirmąsias 14 parų, kai polistireninis putplastis laikomas gamykloje. Ribinè vèlyvoji susitrauktis pasiekiama po 150 parų.

Imirkis. Polistireninio putplasčio įmirkis nustatomas tūrio procentais. Kadangi akelių sienelès vandeniui nelaidžios, vanduo i putplasti gali įsiskverbti tik mažyčiais kanalèliais tarp susilydžiusių akelių. 15$30 \mathrm{~kg} / \mathrm{m}^{3}$ tankio polistireninio putplasčio imirkis: po 7 parų yra iki 1,5 \% tūrio, po 28 parų - iki $3 \%$ tūrio. Panardinto vandenyje polistireninio putplasčio ilgalaikio įmirkio tyrimo rezultatai naudojami nustatant gaminių tinkamumą naudoti drègmès poveikio zonose.

Valkšnumas. Veikiant $0,30 \sigma_{10}$ gniuždymo ittempiui, polistireninio putplasčio gaminiai po 50 metų turès ne didesnę kaip $2 \%$ valkšnumo deformacija. Valkšnumas svarbus polistireninio putplasčio gaminiams, kurie konstrukcijoje nuolat veikiami statinių ir dinaminių apkrovų.

Ekologiškumas. Polistireninis putplastis netirpsta vandenyje, todèl neskleidžia jokių tirpių medžiagų, galinčių užteršti požeminius 
vandenis. Jis nepūva ir netrūnija, todèl jokiomis kenksmingomis medžiagomis neužteršia dirvožemio.

Polistireniniame putplastyje nèra formaldehido, jis nèra radioaktyvus: neskleidžia alfa, beta ar gama spindulių. Tai inertiška, iprastomis sąlygomis nenuodinga, netoksinè ir nedirginanti medžiaga. I rinką tiekiamas polistireninis putplastis neišskiria nei stireno, nei pentano.

Ilgaamžiškumas. Ilgiau veikiamas tiesioginių ultravioletinių spindulių, polistireninis putplastis pagelsta, jo paviršius darosi trapus. Dèl lietaus ir vèjo gali prasidèti polistireninio putplasčio erozija. Nuo šių poveikių apsaugo medžiagos dažymas, tinkavimas, laminavimas ir pan. Pastato viduje ultravioletinis spinduliavimas yra menkas, todèl polistireniniam putplasčiui tai nedaro jokio poveikio.

Polistireninis putplastis visiškai išlaiko termoizoliacines bei mechanines savybes ir atlieka savo funkcijas per visą pastato gyvavimo trukmę, kuri šiandien apibrèžiama 50 metų.

Degumas. Ilgiau veikiamas didesnès negu $100{ }^{\circ} \mathrm{C}$ temperatūros, polistireninis putplastis ima minkštèti, trauktis ir galiausiai lydytis. Anot gamintojuc, bandymai rodo, kad polistireninio putplasčio su degumą slopinančiais priedais degumo temperatūra yra $374{ }^{\circ} \mathrm{C}$. Esant žemesnei temperatūrai degių dujų nesusidaro. Terminio irimo produktai užsidega tik tiesiogiai susilietę su paviršiais ar erdvèmis, kurių temperatūra yra $450-500{ }^{\circ} \mathrm{C}$. Polistireninis putplastis savaime neužsidega esant žemesnei nei $450{ }^{\circ} \mathrm{C}$ temperatūrai.

Atsparumas senejimui. Polistireninis putplastis nepūva, nedūla ir yra atsparus senèjimui. Senèjimu vadinamas procesas, kai medžiagos savybès tam tikromis gamtinėmis aplinkos sąlygomis kinta nepaisant to, kad tenkinami jos eksploatavimo reikalavimai. Senejjimą rodo medžiagos negebejjimas atlikti numatytų funkcijų ar irimas.

Atsparumas juairiu cheminiu medžiagu poveikiui. Polistireninio putplasčio gaminiai konstrukcijoje neturi liestis su jokia medžiaga, kuri juos ardytų ar plèstų. Polistireninis putplastis gali susitraukti ar net suirti ilgai veikiamas šių medžiagų: augalinio aliejaus, parafininès alyvos, vazelino, dyzelinès alyvos, metilo ir etilo spirito. Polistireninis putplastis neatsparus: šaltam bitumui ir bituminiam glaistui; degutui, 
deguto tepalui; organiniams skiedikliams (acetonui, benzinui, terpentinui, acto esencijai ir kt.); sotiesiems angliavandeniliams (cikloheksanui, vaitspiritui); dyzeliniams ir karbiuratoriniams degalams.

Polistireninis putplastis atsparus: vandeniui, kuriame yra padidinta druskų koncentracija; kalkèms, cementui, gipsui, anhidritui; natrio ir kalio šarmams; $35 \%$ druskos rūgščiai, iki $50 \%$ azoto rūgščiai, iki $95 \%$ sieros rūgščiai, druskoms, trąšoms; silikono alyvai, amoniakui.

\subsubsection{XPS polistireninio putplasčio gamyba ir savybès}

Ekstruzinio polistireninio putplasčio (angl. Extruded Polystyre$n e$, XPS) žaliava, kaip ir EPS polistireninio putplasčio, yra polistirenas, tačiau jų gamybos technologija iš esmès skiriasi. Ekstruzinis polistireninis putplastis pradètas gaminti maždaug prieš $60 \mathrm{~m}$. Jungtinèse Amerikos Valstijose. Kaip putokšliai gali būti naudojamos sistemos freono pagrindu, o šiuo metu dažniausiai naudojami putokšliai anglies dioksido $\left(\mathrm{CO}_{2}\right)$ pagrindu. Gaminant XPS putplasti pagrindinis irenginys yra ekstruderis. Pagrindinis ekstruderio uždavinys - išlydytą polimerą sumaišyti su priedais ir formavimo galvute suteikti jam forma. Gamyboje naudojami keli ekstruderiu tipai: vienastraigtis (2.6 pav.) ir dvisraigtis. XPS polistireninis putplastis gaunamas maišant polistireno granules su ivairiais priedais (pvz., antipirenais, dažalais) ir putokšliu aukštoje temperatūroje. Pradinès žaliavos tiekiamos i ekstruderi (2.6 pav.), kuriame jos lydomos ir išmaišomos, esant aukštai temperatūrai. I paruoštą masę dideliu slègiu iterpiamas putokšlis ir gaunamas klampus vientisas lydalas. Jis išspaudžiamas per ekstruderio galvutę. Gautas pusgaminis aušinamas ir supjaustomas i tam tikro dydžio gaminius.

Putokšlis išgaruoja iš plokščių per kelias savaites nuo pagaminimo ir pakeičiamas oru. Polistireno ir putokšlio dalis mišinyje yra apie 96$98 \%$. Likusią dali sudaro papildomos medžiagos: dažalai, proceso stabilizavimo medžiagos, porų struktūros modifikavimo medžiagos ir t. t. 


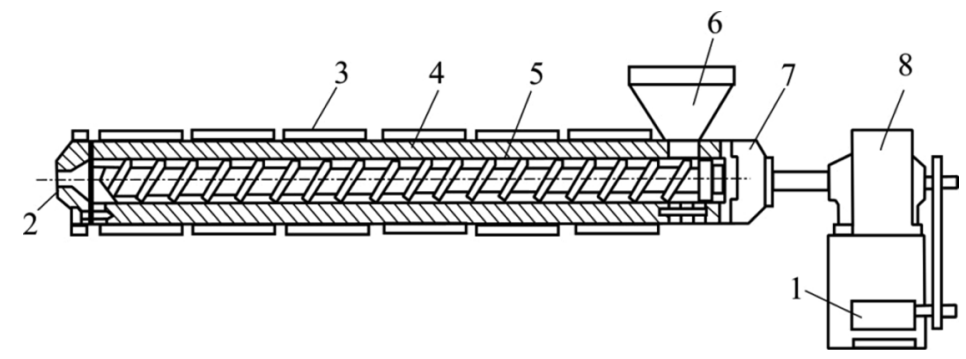

2.6 pav. Principinè ekstruderio schema: 1 - variklis; 2 - ekstruderio galvutė; 3 - korpuso šildytuvas; 4 - ekstruderio korpusas; 5 - sraigtas;

6 - krovimo anga; 7 - atraminis guolis; 8 - reduktorius

Ekstruzijos būdu pagaminti gaminiai pasižymi geromis fizikinėmis ir mechaninėmis savybėmis, kurios priklauso nuo porų struktūros. Gaminių struktūra yra visiškai vientisa ir uždara.

XPS polistireninio putplasčio gaminiai netrūnija, nepūva, jiems būdingas geras cheminis atsparumas, mažas šilumos laidumo koeficientas, labai mažas vandens įmirkis, didelis stipris.

Statybos reikmėms gaminamas $25-45 \mathrm{~kg} / \mathrm{m}^{3}$ tankio ekstruzinis polistireninis putplastis. Šios medžiagos uždara ir absoliučiai vientisa porų struktūra gerai sulaiko nejudanti ora, kurio šilumos laidumo koeficientas $\left(\lambda_{10}\right)$ yra $0,026 \mathrm{~W} /(\mathrm{m} \cdot \mathrm{K})$. XPS polistirenio putplasčio gaminiu šilumos laidumo koeficientas, priklausomai nuo gaminio tipo, yra $0,029-0,45 \mathrm{~W} /(\mathrm{m} \cdot \mathrm{K})$, imirkis ne didesnis kaip 0,9\% nuo tūrio, gniuždymo stipris, kai bandinys deformuojamas $10 \%$, didesnis kaip 0,29 $\mathrm{MPa}$, lenkimo stipris - 0,45 $\mathrm{MPa}$, tempimo stipris - 0,3 $\mathrm{MPa}$.

\subsubsection{Polistireninio putplasčio gaminiai ir juc naudojimas}

Gaminiai iš polistireninio putplasčio naudojami naujų, restauruojamų, remontuojamų pastatų vidaus ir išorès sienoms šiltinti, plokščių ir šlaitinių stogų termoizoliacijai, perdangų, grindų ir pamatų konstrukcijose. 
Iš polistireninio putplasčio gaminamos polistireninio putplasčio plokštès, kurios gali būti naudojamos pastatų sienoms, stogams, perdangoms, grindims, pamatams šiltinti.

Atitvarų, kurioms šiltinti naudojamas EPS polistireninis putplastis, apibūdinimas ir naudotini putplasčio tipai pagal ST 124555873. 01:2005 „Atitvarų šiltinimas polistireniniu putplasčiu“ pateikti žemiau.

1. Siena:

- išorinè rūsio siena su išorine šilumos izoliacija, apsaugota nuo mechaninių pažeidimų; apkrova, veikiant šilumos izoliacijai, yra vidutinè - EPS 100;

- išorinè rūsio siena su išorine šilumos izoliacija, apsaugota nuo mechaninių pažeidimų; apkrova, veikiant šilumos izoliacijai, yra didele - EPS 150;

- fasadų šiltinimas - išorinè siena su šilumos izoliacija išorèje, padengta tinku, - EPS 70;

- išorinè siena su išorine šilumos izoliacija, padengta lakštiniais elementais, dailylentemis, skarda ir pan., - EPS 50;

- išorinè sluoksniuota siena su šilumos izoliacija viduje EPS 50;

- išorinè siena, apšiltinta iš vidaus, - EPS 50;

- išorinè karkasinio pastato siena (skydinè) - EPS 50.

2. Stogas:

- Stogas, apšiltintas virš gegnių arba kitokių laikančiųų konstrukcijų. Standi arba kieta danga virš šilumos izoliacijos (čerpès, betonas, profiliuota skarda ir pan.) - EPS 80;

- stogas su šilumos izoliacija tarp gegnių - EPS 50;

- stogas su šilumos izoliacija po gegnėmis, apšiltintas patalpoje (iš vidaus) - EPS 50;

- sutapdintas stogas, apšiltintas dviem skirtingais polistireninio putplasčio sluoksniais. Viršutinis EPS sluoksnis užtikrina stogo mechanini stiprį - EPS 100, apatinis - pakankamą šilumos izoliavimą - EPS 80; 
- stogas su šilumos izoliacija, apsaugota ritinine danga nuo atmosferos kritulių; stogo apkrova vidutinè - EPS 100;

- stogas su šilumos izoliacija, apsaugota ritinine danga nuo atmosferos kritulių; stogo apkrova didelè (terasos, apželdinti stogai ir pan.) - EPS 150;

- stogas su šilumos izoliacija, neapsaugota nuo atmosferos kritulių, - atvirkštinis stogas, EPS 200.

3. Grindys:

- grindys su šilumos izoliacija, esančia po išlyginamuoju betono sluoksniu; garso izoliacijos reikalavimų nekeliama; apkrova, veikianti grindų paviršių, maža (gyvenamuosiuose, administraciniuose, poilsio ir pan. pastatuose) - EPS 70;

- grindys su šilumos izoliacija, esančia po išlyginamuoju betono sluoksniu; gali būti salytis su gruntu; garso izoliacijos reikalavimų nekeliama; apkrova, veikianti grindų paviršių, vidutinè (salèse, kavinèse, restoranuose ir pan.) - EPS 100;

- grindys su šilumos izoliacija, esančia po išlyginamuoju betono sluoksniu; gali būti sąlytis su gruntu; garso izoliacijos reikalavimų nekeliama; grindų paviršių veikianti apkrova yra didelè (knygų saugyklose, archyvuose, pramonès imonèse, automobilių parkavimo aikštelèse, baseinuose ir pan.) - EPS 200;

- šildomos grindys gyvenamuosiuose ir viešosios paskirties pastatuose - EPS 80;

- šaldytuvų, vaisių, daržovių, mėsos ir kitų maisto produktų saugyklų grindys - EPS 200;

- garsą izoliuojančios atitvaros, esant nedideliam, vidutiniškai padidintam spūdumui, - EPS T.

\subsection{Polivinilchloridas (PVC)}

Šiuo metu polivinilchloridas yra plačiausiai naudojamas termoplastikas. Pirmą kartą ši polimerą 1872 metais atsitiktinai atrado vokiečių mokslininkas Eugenas Baumanas. 1912 metais mokslininkas F. Klatte'as parengè teorinius pagrindus šiam polimerui gaminti. 
Pramoniniu mastu PVC produkcija pradèta gaminti 1938 metais. Polivinilchlorido granulių bendras vaizdas pateiktas 2.7 pav., a. Europoje PVC atlieku tvarkymo plètrą stebi $2000 \mathrm{~m}$. isteigtas juridinis subjektas „Vinyl 2010“. Ši organizacija numato atlieku tvarkymo metodus ir stebi, kad žaliavos būtų naudojamos kaip imanoma veiksmingiau. $2010 \mathrm{~m}$. buvo perdirbta 260,8 tūkst. tonų PVC atliekų, t. y. 220 tūkst. tonų daugiau nei 1999 metais. Polivinilchlorido identifikacijos kodas pateiktas 2.7 pav., b.

a

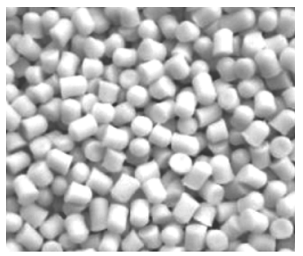

b

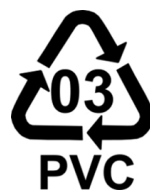

2.7 pav. Polivinilchlorido granulių vaizdas (a), polivinilchlorido identifikacijos kodas (b)

\subsection{1. Žaliavos ir gamyba}

Polivinilchloridas sintetinamas iš vinilchlorido radikalinès polimerizacijos būdu:<smiles>CC(Cl)C(C)C(C)CCl</smiles>

Polimerizuojama kondensuotame monomere, suspensijoje arba emulsijoje. Pramoniniu būdu vinilchloridas gaminamas chlorinant etileną ir pirolizuojant susidariusị dichloretaną. Polivinilchloridas iš vinilchlorido polimerizacijos metu gaunamas trimis būdais: polimerizuojant masèje (gaunama apie $11 \%$ medžiagos); emulsijoje; suspensijoje.

Apie 70-75\% polivinilchlorido pramoneje gaminama suspenksinès polimerizacijos būdu. Polimerizacijos procesas baigiamas, kai 
monomero konvekcijos laipsnis siekia 75-90 \%. Gautas polimeras iš suspensijos nusodinamas pridejus elektrolito. Vinilchloridas yra nuodinga žaliava, galinti sukelti ịvairių susirgimų, todèl monomero likučiai iš suspensinio polivinilchlorido šalinami šildant polimerą vakuume arba šutinant vandens garuose.

Principinè polivinilchlorido gamybos schema, kai gaminama suspensiniu būdu, taikant du džiovinimo variantus, pateikta 2.8 pav. I polimerizacijos reaktorių, kurio tūris, tarkim, yra $10 \mathrm{~m}^{3}$, idedama $3000 \mathrm{~kg}$ vinilchlorido, $6000 \mathrm{~kg}$ vandens, $4 \mathrm{~kg}$ suspensijos agento, 2-4 kg iniciatoriaus.

Gautas polivinilchloridas gali būti perdirbamas i kietojo PVC (viniplasto) arba minkštojo PVC dirbinius. Kadangi i polivinilchlorido sudèti ieina chloras, gamybos procese sunaudojama mažiau etileno, todèl PVC tampa santykinai pigesne medžiaga nei polietilenas ar polipropilenas.

Kietasis PVC kaitinamas $120-190^{\circ} \mathrm{C}$ temperatūroje, o iš gauto lydalo formuojami dirbiniai. Toks PVC yra gana atsparus atmosferos poveikiui. Iš kietojo PVC gaminami vamzdžiai, konstrukcinès detalès, lakštai, langų ir durų rèmai.

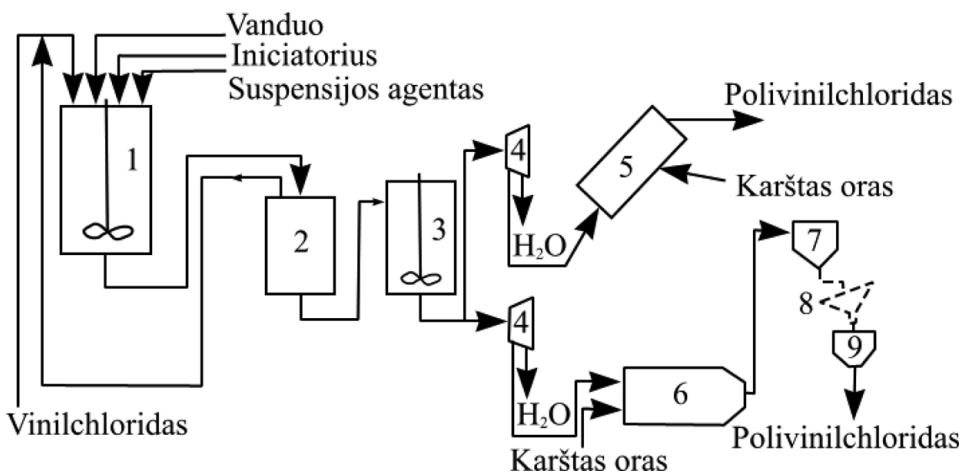

2.8 pav. Principinè polivinilchlorido gamybos (esant dviem džiovinimo variantams) schema: 1 - polimerizacijos reaktorius; 2 - separatorius, kuriame atskiriamas nesureagavęs vinilchloridas; 3 - maišymo įrenginys; 4 - centrifuga; 5 - greito džiovinimo įrenginys; 6 - džiovinimo būgnas; 7 - polimero surinktuvas; 8 - sijojimo mazgas; 9 - ciklonas dulkèms surinkti 
Minkštasis PVC gaminamas iš PVC ir 10-40 \% plastifikatorių mišinio (dažniausiai naudojami ftalatai), gamybos metu paruošiamas homogeniškas mišinys, kuris formuojamas $160-180{ }^{\circ} \mathrm{C}$ temperatūroje. Minkštas PVC naudojamas kaip elektroizoliacinè medžiaga, iš kurios gaminamos grindų dangos, dirbtinès dangos. Minkštasis PVC atsparus daugkartinèms deformacijoms.

Ekstrudiniu būdu gali būti formuojami vienasluoksniai ir daugiasluoksniai gaminiai. Statyboje naudojami tokie ekstrudiniu būdu pagaminti dirbiniai: vamzdžiai, šuliniai, langų rèmai, palangès, grindjuostès, plastikinès dailylentès.

Vienasluoksniu dirbiniu gamybos technologija. Principinė PVC ekstrudinių dirbinių gamybos technologinè schema pateikta 2.9 paveiksle.

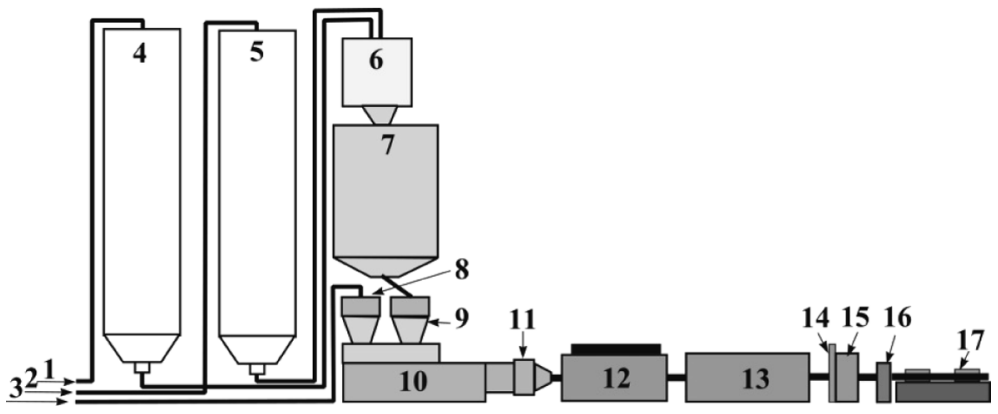

2.9 pav. Principinè technologinė PVC ekstrudinių dirbinių gamybos schema: 1 - užpildas; 2 - plastiko žaliava; 3 - perdirbti skirti neatitiktiniai dirbiniai; 4 - užpildo talpykla; 5 - plastiko žaliavos talpykla; 6 - maišymo irrenginys; 7 - paruoštos masès talpykla; 8 - trupintų dirbinių tiekimo įrenginys; 9 - masės tiekimo įrenginys; 10 - ekstruderis; 11 - formavimo irenginys; 12 - kalibratorius su vakuuminiu aušintuvu; 13 - aušinimo vonelè;

14 - žymèjimo įrenginys; 15 - griebtuvas; 16 - pjaustymo įrenginys;

17 - gaminio nuèmimo nuo linijos įrenginys

PVC granuliu pavidalo i gamyklą gali būti atvežamas automobilių transportu. Iš autovežio cisternos PVC pneumatiniu siurbliu iškraunamas i silosus, kuriuose laikomas ir sandèliuojamas. Iš silosų PVC granulès patenka į malimo ir maišymo įrengini, kuriame sumai- 
šomos su užpildu ir stabilizatoriumi. Mišinys permalamas, užtikrinant masès homogeniškumą ir vienodą dalelių skersmeni. Paruoštas mišinys sandèliuojamas bunkeryje, iš kurio pro dozavimo irangą tiekiamas i estruderị. Užpildas taip pat gali būti atvežamas automobilinèmis cisternomis ir sandèliuojamas silosuose arba atvežamas $1 \mathrm{t}$ maišuose ir laikomas sandèliuose. Iš silosų arba iš maišų užpildas pneumatiniais siurbliais tiekiamas i malimo ir maišymo vietą. Malimo ir maišymo vietoje i mišini pridedama ir stabilizatoriaus mišinio, kuris atvežamas automobiliniu transportu maišuose po $25 \mathrm{~kg}$. I maišymo įrenginị stabilizatorius dedamas rankiniu būdu.

Mišinys iš sandèliavimo bunkerio toliau apdirbti per dozatorių tiekiamas ì ekstruderị, kuriame išlydomas. Tiekimo metu mišinys eidamas vamzdžiais nuo trinties ịkaista ir tampa pradinès temperatūros. Ekstruderyje yra sraigtai, kurie besisukdami stumia ikaitintą plastiko mišini pirmyn paversdami ji formuoti tinkama mase. Eksruderyje temperatūra pakeliama iki $195^{\circ} \mathrm{C}$ ir joje mišinys išsilydo. Tokios būsenos jis tampa lengvai formuojamas - galima formuoti vientisą ar kombinuotaji nenutrūkstamą gamini. Tuo metu vykstant nenutrūkstamam tiekimui jau išlydyta žaliava stumiama i dirbinio formavimo galvutę, esančią formavimo irenginyje. Formavimo galvutèje temperatūra siekia iki $210^{\circ} \mathrm{C}$. Bendras suformuoto nenutrūkstamo PVC dirbinio, išejjusio iš formavimo įrenginio, vaizdas pateiktas 2.10 pav.

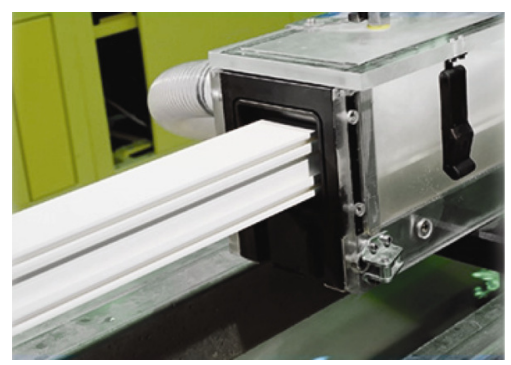

2.10 pav. Bendras suformuoto PVC dirbinio, išèjusio iš formavimo ịrenginio, vaizdas 
Suformuotas dirbinys toliau patenka i kalibratorių, kuriame jam suteikiamas tikslus išorinis matmuo. Užtikrinti ypač tikslų sienelès stori galima naudojant ultragarsini kalibratorių, kuris matuoja dirbinio sienelès stori ultragarsu. Iš kalibratoriaus dar šiltas ką tik suformuotas ir kalibruotas dirbinys patenka i vakuuminę aušinimo vonelę. Joje palaikomas pastovus slègis, neleidžiantis dirbiniui subliukšti, deformuotis ar kitaip pakeisti igytą forma, kol dirbinys pasieks optimalią temperatūrą. Dirbinys, eidamas per vakuuminị aušintuvą, per laistymo angas visą laiką laistomas tam tikros temperatūros vandeniu. Dirbinys, atvėsintas vakuuminiame aušintuve, jau išlaiko suteiktą formą ir galutinai ataušti toliau nukreipiamas i paprastą aušinimo vonelę, kurioje atvėsinamas vandens čiurkšlèmis. Linijos pastoviajam greičiui užtikrinti reikalingas griebtuvas, kuris pastoviuoju greičiu dirbini traukia per visą gamybos liniją. Greitis turi būti pritaikytas prie kitų linijos irenginių pajègumų, svarbiausia - prie pagrindinio ịrenginio ekstruderio žaliavos lydymo greičio. Paprastai linija juda apie $4 \mathrm{~m}$ per minutę greičiu. Atvėsintas dirbinys jau atitinka visus jam keliamus reikalavimus, bet prieš tai ji dar reikia pažymeti, supjaustyti ir pašalinti iš gamybos linijos. Dirbinys iš griebtuvo stumiamas i pjaustymo irrengini, kuris, prisitaikydamas prie gamybos linijos greičio, pjausto ji ivvairiais gamyklos nustatytais ilgiais. Dirbinys žymimas tam tikrais intervalais. Žymejjimo irenginys pažymi pagamintą produkcija, ant dirbinio užrašydamas: pagaminimo data, standarto numerị, atsparumo klasę, partijos numeri. Tai padeda užtikrinti dirbinio kokybę, ištaisyti gamybos broką, nustatyti ir pašalinti jo atsiradimo priežastis.

Daugiasluoksniu dirbiniu gamybos technologija. Pastaraisiais metais pradètos naudoti naujos plastikinių dirbinių gamybos technologijos. Šios technologijos pritaikytos daugiasluoksniams dirbiniams gaminti. Tai dirbiniai, kuriems gaminti naudojami skirtingo tankio plastiko sluoksniai. Daugiasluoksniai dirbiniai gaminami dèl keleto priežasčių: jie yra lengvesni, pigesni, puikių mechaninių savybių, tikslesnių matmenų ir labai atsparūs mechaniniams poveikiams. Pavyzdžiui, pagal šią technologiją gaminamų vamzdžių yra daugiau nei 
$50 \%$ iš visų Europos Sajungoje parduodamų išorès nuotekų tinklu vamzdžių. Daugiasluoksnio dirbinio sienelès pjūvis pateiktas 2.11 pav. Dirbinio vidurinis sluoksnis yra pagamintas iš išputinto PVC.

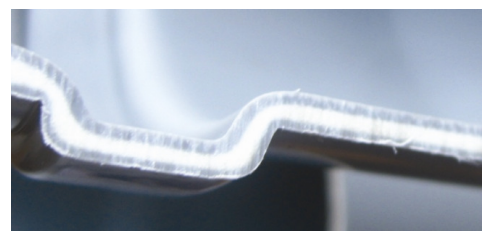

2.11 pav. Daugiasluoksnio dirbinio pjūvis

Pagal nagrinejjamą daugiasluoksnių dirbinių technologiją karšto plastiko sluoksniai išspaudžiami i formavimo irengini, kuriame sluoksniai sulydomi i vieną gaminio sienelę, suformuojant ištisini gamini. PVC, kuris naudojamas vidiniam sluoksniui, tankis yra apie $900 \mathrm{~kg} / \mathrm{m}^{3}$. Vidinio sluoksnio medžiagos tankis mažesnis, nes jam suformuoti naudojami poras sudarantys priedai.

Daugiasluoksnio dirbinio gamybos technologijos pagrindiné idèja yra ta pati kaip ir tejjinès sijos. Didžiausi įtempiai susidaro vamzdžio viršutinèje ir apatineje sienelès dalyje, o vidurinis sluoksnis yra kaip rišamasis. Esant tokiai konstrukcijai, dirbinio stipris sumažeja nereikšmingai, o vartotojas gauna tokios pačios kokybès dirbini, tik už mažesnę kainą.

Vidiniams sluoksniams iprasta naudoti lengvesnę ir mažesnio stiprio medžiaga, nes ši sluoksnị veikia ne tokie dideli mechaniniai itempimai, fizikiniai ir cheminiai veiksniai, tokie kaip UV spinduliavimas ir ivvairi tarša.

Skirtingai nuo vienasluoksnių dirbinių, daugiasluoksniams dirbiniams gaminti naudojamas ne vienas, o du ekstruderiai - vienas išoriniams sluoksniams, kitas vidiniam sluoksniui formuoti.

Daugiasluoksnis dirbinys suformuojamas formavimo galvutèje. Gaminamo dirbinio skersmuo ir sienelès storis priklauso būtent nuo šio įrenginio. Gaminant PVC daugiasluoksni dirbinį formavimo galvuteje temperatūra siekia iki $210^{\circ} \mathrm{C}$. Šiame irenginyje vidinis ir 
išoriniai sluoksniai patikimai sukimba ir sudaro vientisą sienelę. Pagaminti toki dirbini tampa imanoma dèl termoplastikų linijinių molekulių grandinių savybès: išsilydžiusios molekulès jungiasi i vientisu grandinių junginius.

Karšto plastiko sluoksniai išspaudžiami i formavimo irengini, kuriame sluoksniai sulydomi i vieną dirbinio sienelę, suformuojant ištisini dirbini. Dvisluoksnio plastiko komponentų maišymo mazgo schema pateikta 2.12 paveiksle, o masių judejjimo trijų sluoksnių dirbinio formavimo principine schema pavaizduota 2.13 pav.

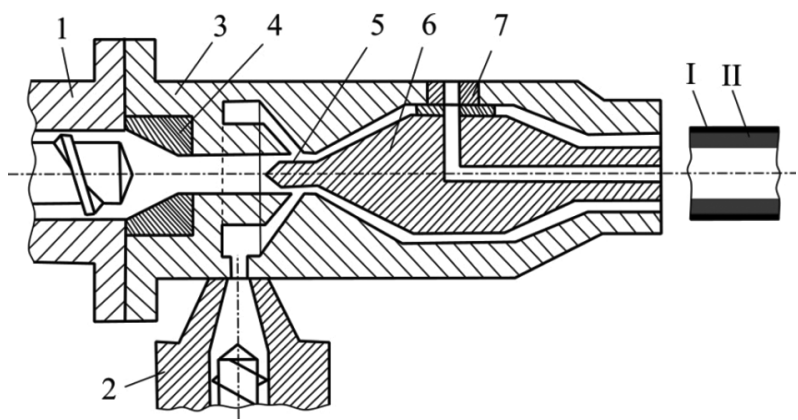

2.12 pav. Dvisluoksnio plastiko komponentų maišymo mazgas:

1 - vidinio sluoksnio ekstruderis; 2 - išorinio sluoksnio ekstruderis;

3 - ekstruderio korpusas; 4 - adapteris; 5 - vidinio sluoksnio skirstytuvas;

6 - tuščio sluoksnio formavimo korpusas; 7 - tuščio sluoksnio formavimo korpuso laikiklis; I - išorinis gaminio sluoksnis;

II - vidinis gaminio sluoksnis

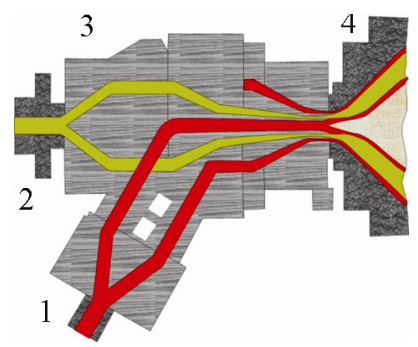

2.13 pav. Plastiko masiu judejjimas trisluoksnio dirbinio formavimo metu:

1 - išorinio sluoksnio ekstruderis; 2 - vidinio sluoksnio ekstruderis;

3 - formavimo įrenginys; 4 - dirbinio formavimo galvute 
Daugiasluoksnio dirbinio iš $\mathrm{PVC}$, gaminamo pagal aprašytą technologija, sluoksniai yra skirtingo tankio:

- vidinis sluoksnis yra $\sim 900 \mathrm{~kg} / \mathrm{m}^{3}$ tankio;

- išoriniai sluoksniai yra $\sim 1430 \mathrm{~kg} / \mathrm{m}^{3}$ tankio.

Bendras PVC daugiasluoksnio dirbinio tankis yra $\sim 1000 \mathrm{~kg} / \mathrm{m}^{3}$, o pavyzdžiui, viensluoksnio dirbinio tankis siekia $1430 \mathrm{~kg} / \mathrm{m}^{3}$.

Pagal daugiasluoksnių dirbiniu gamybos technologiją vidini putintą dirbinio sluoksni galima gauti iki $500 \mathrm{~kg} / \mathrm{m}^{3}$ tankio, tačiau mažinant vidinès sienelès tankị mažèja putinto PVC sluoksnio stipris. Minimalus rekomenduojamas putinto PVC sluoksnio tankis yra $800 \mathrm{~kg} / \mathrm{m}^{3}$, kai PVC putinimo laipsnis $-57 \%$.

Naudojant putintą vidini sluoksni gaunama medžiagų ekonomija. Palyginus išorinių sluoksnių ir vidinio sluoksnio santykị matyti, kad net $44 \%$ bendros masès sudaro išoriniu sluoksnių masè, o išoriniu sluoksnių storis yra apie 3-4 kartus mažesnis nei vidinio sluoksnio.

Gaminant vidini putintą dirbinio sluoksni gali būti naudojamos dvi mažo tankio medžiagos gavimo technologijos. Pirmoji, kai daugiasluoksnio vamzdžio gamybos metu suspaustos dujos (azotas arba anglies dioksidas) iterpiamos i jau išlydytą plastiko mišini sraigte. Dujų, sumaišytų su plastiku, mišinys slegiamas ir transportuojamas i tarp dviejų išorinių dirbinio sluoksnių susidarančią ertmę. Kalibravimo irenginys, kalibruojantis išorinius daugiasluoksnio dirbinio sluoksnius, montuojamas taip arti formavimo įrenginio žiočių, kad vidinio sluoksnio putinimas vyktų ir kalibravimo irenginyje. Kitas išputinto sluoksnio gavimo būdas yra putinimo cheminio agento iterpimas i plastiko masę - tada gaunamas mažesnis nei $50 \%$ išputinimo laipsnis, o sluoksnio tankis yra palyginti didelis.

Grindu dangos (linoleumo) gamybos technologija. Iš polivinilchlorido ir priedų (plastifikatorių, pigmentų, technologiniu priedų) gaminamos grindų dangos - linoleumai, plytelès. Principinè PVC linoleumo gamybos schema pateikta 2.14 pav.

Linoleumas gaminamas valcavimo būdu, naudojant prietaisus kalandrus. Valcavimas - tai medžiagos apdirbimas leidžiant ją tarp 


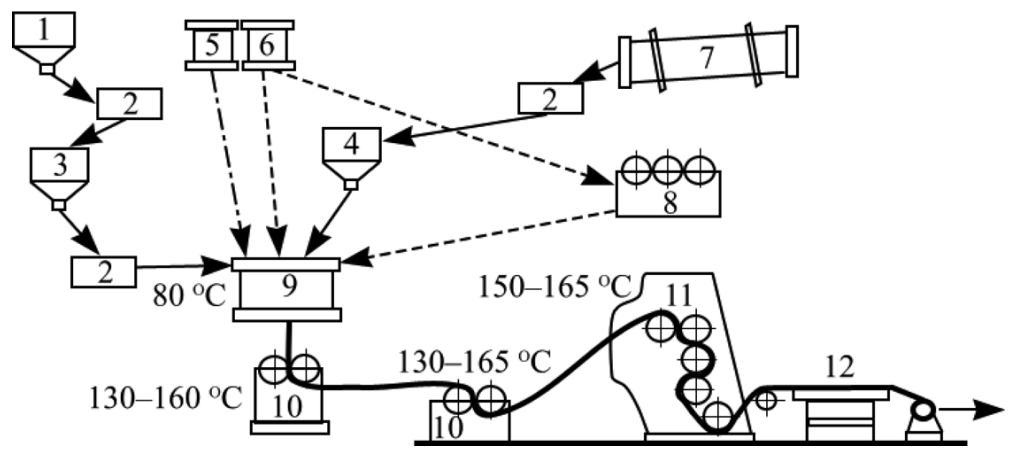

2.14 pav. Principinė PVC linoleumo gamybos schema:

1, 3 - PVC bunkeriai; 2 - vibraciniai sietai; 4 - bunkeris priedams;

5, 6 - ivvairių priedų dozavimo îrenginiai; 7 - džiovinimo būgnas

(priedams); 8 - papildomas priedų bunkeris (pvz., dažu); 9 - maišymo irenginys; 10 - valcavimo įrenginys; 11 - kalandras (suspaudimo velenai),

12 - apipjaustymo įrenginys

dviejų skirtingomis kryptimis besisukančių velenų. Gamyboje naudojami kalandrai, kuriuose yra besisukančių velenų sistema. Kalandruose judanti juosta apdorojama spaudžiant tarp dviejų arba daugiau velenų. Apdorojimo tikslas: juostos išlyginimas, blizgesio suteikimas (sauso apdorojimo kalandre), reljefinio rašto sudarymas (ispaudimo kalandre) ir kt. Gautas reikiamo storio gaminys dažnai derinamas su ivairaus tipo dervomis impregnuotais arba paprastais tekstiliniais audiniais. Kalandrai taip pat dažnai naudojami ir daugiasluoksniams kompozitams gaminti.

Polivinilchloridas ir îvairūs priedai maišymo îrenginyje apie $2 \mathrm{~h}$ maišomi $80^{\circ} \mathrm{C}$ temperatūroje, paskui masè apie $24 \mathrm{~h}$. išlaikoma $20{ }^{\circ} \mathrm{C}$ temperatūroje. Toliau masė tiekiama i valcavimo įrenginius, kuriuose palaikoma $130-160^{\circ} \mathrm{C}$ temperatūra, vèliau ji pjaunama peiliais ir nukreipiama i kalandra. Kalandre garai palaiko 150$165^{\circ} \mathrm{C}$ temperatūra. Po valcavimo gaunamas reikiamo storio gaminys. Toliau gaminys aušinamas, apipjaustomas ir pakuojamas. 


\subsubsection{Polivinilchlorido savybès}

Pagrindinès polivinilchlorido savybès pateiktos 1.2 lenteleje. Pagal naudotus priedus gaminant dirbinius iš polivinilchlorido yra išskiriamas neplastifikuotas polivinilchloridas PVC-U. I jo sudetį neieina ftalatų arba kitu kenksmingų plastifikatorių, tokių kaip BPA - organinių junginių su dviem fenolinėmis funkcinèmis grupèmis.

Polivinilchloridas tirpsta cikloheksanone, kai kuriuose chlorintuose angliavandeniliuose, tetrahidrofurane. Kambario temperatūroje jis yra atsparus rūgštims ir šarmams, vandeniui ir alkoholiams. PVC stiklejjimo temperatūra yra $8{ }^{\circ} \mathrm{C}$; jis neatsparus šilumos ir šviesos veikimui; $100-120^{\circ} \mathrm{C}$ temperatūroje pradeda atskilti vandenilio chloridas, o palaikytas tokioje temperatūroje ilgesnį laiko tarpą tampa trapus; $140^{\circ} \mathrm{C}$ temperatūroje pradeda irti. Vinilchloridas susidaro apšvitinus polimerą ultravioletine spinduliuote. Šią reakciją galima sustabdyti išsiskiriantị $\mathrm{HCl}$ surišant stabilizatoriais: neorganinèmis arba organinemis švino druskomis, cinko organiniais junginiais, epoksidais. Stabilizuotas PVC išlaiko trumpalaikę $190^{\circ} \mathrm{C}$ temperatūrą, termiškai apdorotas tampa atsparus atmosferos poveikiui.

\subsubsection{Gaminiai ir jų naudojimas}

Vamzdynai iš polivinilchloridinių dirbiniu - tai efektyvios inžinerinès sistemos. Šių inžinerinių sistemų naudojimo patirtis leidžia teigti, kad jos turi nemažai privalumų lyginant su metalinėmis medžiagomis. Plastikiniai vamzdžiai gali būti naudojami irengiant naujus tinklus ir renovuojant jau susidevejusius.

Polivinilchloridiniai vamzdžiai jau daugeli metų naudojami visose pasaulio šalyse. Polivinilchloridiniai vamzdžiai turi puikiu savybių - sistemos hidrauliškai patikimos, jungtys sandarios, vamzdžiai patvarūs, nedaug sveria, atsparūs korozijai, nusidèvejjimui. Vamzdžiai iš polivinilchlorido vandentiekio inžinerinèse sistemose pradèti naudoti vieni iš pirmujų. Jie naudojami šaltam vandeniui tiekti, taip pat maisto pramonès technologinèms sistemoms, kanalizacijos tinklams. Vamzdžiai iš šios medžiagos patogūs naudoti dèl 
šių savybių: montavimo darbams nereikalingi specialūs irankiai; sujungiami movomis arba klijuojami; pakankamai standūs; juos galima paslèpti konstrukcijose ir naudoti neuždengtus; žaliavos, naudojamos šiam plastikui gauti, yra vienos iš pigesnių. Vamzdžiai yra ilgaamžiai - net veikiami agresyvių nutekamujų vandenų puikiai išlaiko savybes. PVC vamzdžiai yra sandarūs, todèl nutekamieji vandenys nenuteka i gruntą ir jo neužteršia, o gruntiniai vandenys nepatenka i kanalizacijos sistemą ir nedidina jos apkrovos. Jie yra lengvi, o tai palengvina montavimą ir didina darbo saugumą.

PVC vamzdžiai atsparūs cheminèms medžiagoms, jų šilumos laidumo koeficientas yra apie $0,16 \mathrm{~W} / \mathrm{m} \cdot \mathrm{K}$. Geriamajam vandeniui skirti vamzdžiai nesuteikia vandeniui jokio skonio ar kvapo. Tokie vamzdžiai nesudaro sąlygų intensyviam mikrobų augimui. Plastikinès medžiagos išsiskiria itin geru atsparumu dèvèjimui.

Jie gali būti naudojami visų rūšių slèginiams ir savitakiams tinklams, kaip apsauginiai vamzdžiai - elektros ir televizijos kabeliams, kaip drenažo vamzdžiai - pramoniniams technologiniams vamzdynams. Paprastai namo kanalizacijai naudojami 50-160 mm skersmens vamzdžiai, tinkantys lietaus vandeniui ir buitiniams nutekamiesiems vandenims. Komunaliniam ūkui ir pramonei skirtos 200-630 mm skersmens kanalizacijos sistemos. Lietaus vandeniui nutekèti naudojami 110-500 mm skersmens vamzdžiai.

PVC vamzdžiai gali būti vienasluoksniai ir daugiasluoksniai. Išorinio sluoksnio tankis gali siekti $\sim 1430 \mathrm{~kg} / \mathrm{m}^{3}$. Vidinio išputinto sluoksnio tankis gali būti $\sim 900 \mathrm{~kg} / \mathrm{m}^{3}$. Jo sienelès storis gali sudaryti nuo 5 iki $20 \mathrm{~mm}$, dažniausiai gaminama $10 \mathrm{~mm}$ storio sienelè. Storesni sluoksniai naudojami siekiant geresnių izoliacinių savybių arba geriau apsaugoti vidini apsaugini sluoksni nuo išorinių itempimų. Kai kurios daugiasluoksnių vamzdžių gamybos technologijos leidžia pagaminti $50 \mathrm{~mm}$ storio vidini išputintą sluoksni, kurio tankis yra tik $100-300 \mathrm{~kg} / \mathrm{m}^{3}$.

Mechaninès vidinio išputinto sluoksnio savybès gali būti lengvai keičiamos naudojant smulkiadispersius užpildus arba plaušinius 
priedus. Šio sluoksnio gniuždymo stipris gali būti padidintas vidiniam sluoksniui naudojant volastonita, iterptą i poliolefino putas.

Langų ir durų rèmai iš PVC pasižymi aukštomis šilumos ir garso izoliacinèmis savybèmis, atlaiko dideles vejjo apkrovas, yra nelaidūs vandeniui. Langų rẻmu̧, pagamintų iš $\mathrm{PVC}$, vaizdas pateiktas 2.15 paveiksle.

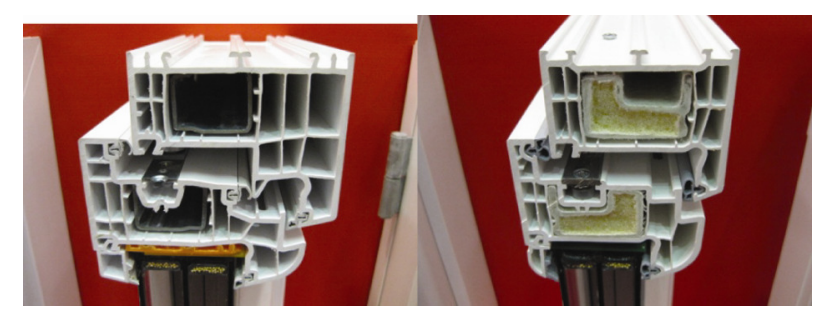

2.15 pav. Langų rẻmų iš $\mathrm{PVC}$ vaizdai: kairèje - rẻmas su armatūra iš plieninių profilių; dešinèje - rèmas su armatūra iš stiklaplasčio

Iš polivinilchlorido, naudojant ịvairius plastifikatorius, tirpiklius, užpildus ir dažiklius, gaminamos įvairios heterogeninès ir homogeninès PVC grindų dangos ir plytelès, linoleumas. Tokia danga yra higieniška, atspari dilimui ir puvimui, lengvai prižiūrima, tačiau jautri aukštoms temperatūroms ir neatspari acetonui bei kitiems stipriems tirpikliams. Atvirame ore PVC dangų naudoti negalima, kadangi esant nepalankioms oro sąlygoms - karščiui, šalčiui, krituliams - jos pradeda irti.

Homogeninès (vienalytės) dangos dažniausiai naudojamos tose vietose, kur daug vaikštoma, t. y. ten, kur medžiaga gali greitai susidèvèti. Homogeninès dangos rekomenduojamos naudoti intensyvaus judejjimo visuomeninèse patalpose, mokymosi ir sveikatos priežiūros istaigose, prekybos centruose, biuruose.

Heterogeninés PVC dangos - tai daugiasluoksnès dangos, susidedančios iš dviejų ar daugiau sluoksnių. Šioms dangoms būdinga sudètingesnè struktūra nei homogeninių dangų. Jų pagrindas - stiklo audinio lakštas, kurio svarbiausios savybès yra tankis ir tvirtumas. Paprastai naudojamas $30-55 \mathrm{~g} / \mathrm{m}^{2}$ tankio stiklo audinys. 
Visos heterogeninès dangos skiriasi tik dangos sluoksnių storiu ir raštais. Dangų pagrindai būna dviejų tipų: cheminiai, mechaniniai. Danga su mechaniniu pagrindu paprastai yra atsparesnè. Toks pagrindas, gaunamas mechaniniu būdu presuojant pagrindo ruošini, yra tankesnis. Cheminis pagrindas gaunamas cheminès reakcijos būdu sukeliant plastiko masès putojimą. Dangos su mechaniniu pagrindu yra standesnès, atsparesnès mechaniniam poveikiui ir, žinoma, brangesnès. Dangos su cheminiu pagrindu yra pigesnès ir dažniausiai klojamos buitinèse patalpose.

Kopolimerizuojant vinilchloridą su 3-20\% vinilacetato acetonu gaunami lakai. Kopolimerizacijos metu susidaro geresnių eksploatacinių savybių ir atsparesnis kopolimeras, kuris yra žaliava plastikiniams šaldytuvų, televizorių, dulkių siurblių korpusams gaminti. Apie parą $60-100^{\circ} \mathrm{C}$ temperatūroje chlorinant ištirpintą $\mathrm{PVC}$ gaunama perchlorvinilinè derva. Ši derva gerai limpa prie metalo paviršiaus, dèl to naudojama metalams dengti rūgštims atspariomis dangomis. Ji tirpsta acetone ir butilacetate, minkšteeja $110^{\circ} \mathrm{C}$ temperatūroje. Perchlorvinilinè derva gali būti naudojama PVC detalèms klijuoti.

\subsection{Polietilenas (PE)}

Polietilenas yra termoplastinis polimeras, susidarantis polimerizuojant eteną. Jis yra vienas iš pigiausių ir plačiausiai naudojamu polimerų. Polietilenas pirmą kartą buvo susintetintas vokiečių mokslininko Hanso fon Pechmano (Hans von Pechmann) 1898 metais. Jis tai padare atsitiktinai, kaitindamas diazometana.

Pramoninè polietileno gamyba esant dideliam slègiui pradèta 1937 metais Anglijoje, o esant mažam - tik 1950 metais Jungtinèse Amerikos Valstijose. Polietilenai skirstomi pagal tanki, kuris priklauso nuo makromalekulių sandaros ir polimero kristališkumo laipsnio (kristalinių ir amorfinių polimerų masių santykis). Polietilenas dažniausiai gaminamas nuo 2 iki $5 \mathrm{~mm}$ granulemis. Bendras polietileninių granulių vaizdas pateiktas 2.16 pav. 


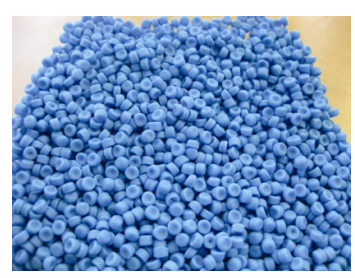

2.16 pav. Polietileno granulių vaizdas

\subsubsection{Polietileno rūšys, žaliavos ir gamyba}

Polietilenas gaminamas polimerizuojant eteno (gali būti vadinamos etileno) dujas esant dideliam arba mažam slègiui. Polietilenas skirstomas į rūšis pagal polimeriniu grandinių šakotumą, nuo jo priklauso kristalinè struktūra ir molekulinis svoris.

Polietileno identifikacijos simboliai pateikti 2.17 paveiksle.

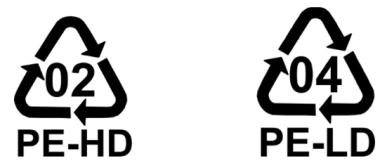

2.17 pav. Polietileno identifikacijos simboliai:

kairèje - didelio tankio polietileno, dešinèje - mažo tankio polietileno

Pagrindinès polietileno rūšys yra šešios:

- labai mažo tankio PE (VLDPE);

- linijinis mažo tankio PE (LLDPE);

- mažo tankio (LDPE) (2.18 pav., a);

- labai didelès molekulinès masès HDPE (UHMW-HDPE);

- didelès molekulinès masès HDPE (HMW-HDPE);

- didelio tankio PE (HDPE) (2.18 pav., b).

Gamintojai naudoja vadinamaji vidutinio tankio PE (MDPE), tačiau tai nèra atskira polietileno rūšis, o HDPE ir LDPE mišinys. Taip pat gaminamas sujungtas $\mathfrak{i}$ trimatị tinklą polietilenas PEX. Jis gali būti trijų rūšių: PEXa, PEXb, PEXc. PEX gaminamas iš sutankinto ir apdoroto specialiuoju būdu polietileno. PEXa tankinamas naudojant perok- 
sidą, PEXb - hidrosilikoniniu būdu, o PEXc - elektronų srautu. Populiariausias yra PEXc. PEXa gamyba yra brangiausia, o gamybos procesas gana sudetingas. PEXc medžiaga yra mažiau lanksti, tačiau atlaiko tą pati darbinị slègi ir temperatūrą kaip ir PEXa.<smiles>C=CCC(CC)CC</smiles>

a<smiles>C=CCC(C)CC</smiles>

b

2.18 pav. Polietileno gavimas iš etileno dujų: a - mažo tankio polietilenas (LDPE), gaunamas radikalinès polimerizacijos būdu, $\mathrm{b}$ - didelio tankio polietilenas (HDPE), gaunamas koordinacinès polimerizacijos būdu naudojant katalizatoriu

Polietilenas apibūdinamas pagal tankị ir lydalo tekejjimo indeksą, kuris rodo suskystintos medžiagos gravimetrini judejimą kaitinant (2.4 lentelè).

2.4 lentelè. Polietileno rūšių savybès

\begin{tabular}{l|c|c}
\hline Polietileno rūšis & Tankis, $\mathrm{kg} / \mathrm{m}^{3}$ & Lydalo tekejjimo indeksas, $\mathrm{g} / 10 \mathrm{~min}$ \\
\hline HDPE & $941-965$ & $0,2-30$ \\
\hline MDPE & $926-940$ & $1-20$ \\
\hline LDPE & $915-925$ & $0,3-26$ \\
\hline LLDPE & $915-925$ & $0,1-100$ \\
\hline VLDPE & $870-914$ & $0,02-10$ \\
\hline
\end{tabular}

Apibendrinant reikia pažymėti, kad $100 \%$ amorfinio PE tankis yra $0,85 \mathrm{~g} / \mathrm{cm}^{3}$, o $100 \%$ kristalinio $-1 \mathrm{~g} / \mathrm{cm}^{3}$. HDPE kristališkumo laipsnis sudaro 60-90\%, o LDPE - 40-50\%. 50\% kristališkumo LDPE šimto anglies atomų grandinèje turi dvi atšakas, o 60-90 \% kristališkumo HDPE - 0,5. Polietileno stiklejjimo temperatūra svyruoja nuo labai žemos iki žemos (nuo $-130 \mathrm{iki}-20^{\circ} \mathrm{C}$ ). Mažo tankio 
polietileno susitraukimas gaminant gaminius yra 1,5-2,0\%, didelio tankio polietileno - 0,75-1,5\%.

Pramoniniu mastu polietilenas gaminamas keturiais būdais. Vienas būdas taikomas, kai polietilenas gaminamas esant dideliam slègiui ir trys - esant mažam.

Mažo tankio polietilenas (LDPE) sintetinamas esant $280 \mathrm{MPa}$ slègiui, temperatūra pakeliama iki $275^{\circ} \mathrm{C}$. Polimerizacija monomere inicijuojama deguonimi arba peroksijunginiais. Pirma, iš leidžiamu per redukuoto vario katalizatoriu eteno dujų šalinamas deguonis. Vèliau, i dujas ịterpus reikiamą deguonies kieki, jos pirmoje kompresorių eilëje suslegiamos iki $30 \mathrm{MPa}$, antroje - iki $280 \mathrm{MPa}$. Toliau mišinys patenka i reaktorių, kuriame vyksta polimerizacijos procesas. Laisvieji radikalai, inicijuojantys radikalinę polietileno polimerizacija, susidaro skylant eteno ir deguonies reakcijos produktuirūgščiajam eteno peroksidui $\left(\mathrm{CH}_{2}=\mathrm{CH}(\mathrm{OOH})\right.$.

Principinè LDPE (didelio slègio) gamybos schema pateikta 2.19 paveiksle.

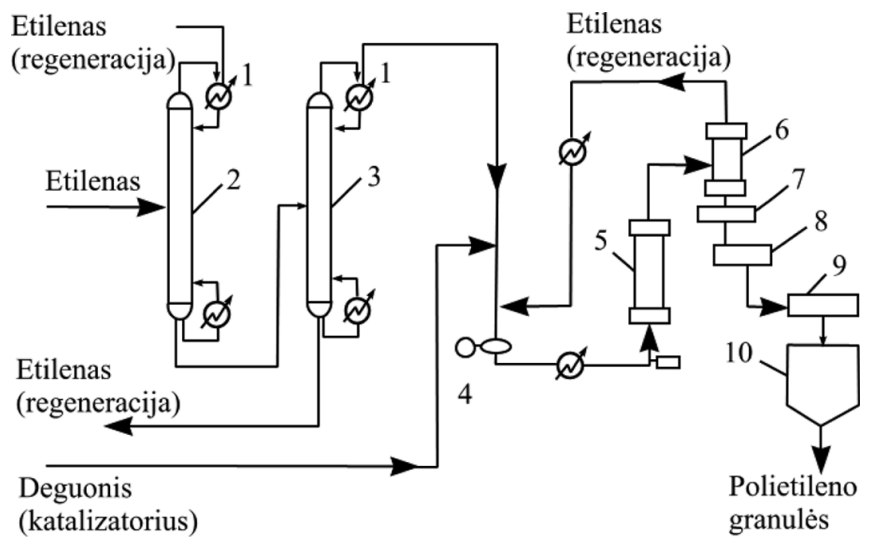

2.19 pav. Principinè LDPE (didelio slègio) gamybos schema:

1 - aušinimo elementai; 2 - pirmoji etileno saugykla; 3 - antroji etileno saugykla; 4 - kompresoriai (pirmasis ir antrasis); 5 - cilindrinis reaktorius; 6 - separatorius, kuriame atskiriamas nesureagavęs monomeras; 7 - granuliatorius; 8 - aušinimo įrenginys; 9 - džiovinimo įrenginys; 10 - polietileno granulių bunkeris 
Gaminant polietileną naudojamas cilindrinis reaktorius arba autoklavas. Cilindrini reaktorių sudaro dvi zonos. Pirmojoje zonoje metilenas, sumaišytas su iniciatoriumi, kaitinamas iki $180^{\circ} \mathrm{C}$ temperatūros, antrojoje - kaitinamas iki $275^{\circ} \mathrm{C}$ temperatūros esant $280 \mathrm{MPa}$ slègiui. Etileno buvimo trukmè reaktoriuje yra 70-100 s, naudingumo koeficientas 18-20\%. Polimerizacijos procesui pasibaigus likęs monomeras atskiriamas nuo išlydyto polietileno ir gražinamas i sintezès pradžią. Gautas polietileno lydalas aušinamas 180$190{ }^{\circ} \mathrm{C}$ temperatūroje ir perdirbamas i granules. Vandeniu ataušintos 60-70 ${ }^{\circ} \mathrm{C}$ temperatūros polietileno granulès vèliau džiovinamos šiltu oru ir pakuojamos i maišus.

Didelio tankio polietilenas (HDPE) sintetinamas bevandenejje terpeje ir esant šiek tiek didesniam negu atmosferinis slègiui, naudojant Ziegler ir Natta (Karl Ziegler ir Giulo Natta - mokslininkai, už atradimus polimeru chemijos ir polimerizacijos technologijų srityje 1963 m. apdovanoti Nobelio premijomis) arba metalų oksidų iniciatorius. Visų mažo slègio polietileno sintezès metodų reakcijos mechanizmas vienodas - augant makromolekulei etenas isiterpia tarp grandinès galo ir iniciatoriaus komplekse esančio kintamojo valentingumo metalo, t. y. vyksta koordinacinè polimerizacija.

Plačiai naudojami trys didelio tankio polietileno gavimo būdai: Ziegler, „Philips“, „Unipols“".

Gaminant polietileną Ziegler būdu iniciatorius yra $\mathrm{TiCl}_{4} /\left(\mathrm{C}_{2} \mathrm{H}_{5}\right)_{2}$ AlCl. Iniciatoriaus efektyvumas (iniciatoriaus gramų kiekis $1 \mathrm{~kg}$ PE) - $3 \mathrm{~g}$, polimero būsena - suspensija heksane, slègis 0,83,5 $\mathrm{MPa}$, temperatūra $50-90{ }^{\circ} \mathrm{C}$, reakcijos trukmè 2-3 val. Polimerizacija vyksta temperatūroje, žemesnejje nei polietileno lydymosi temperatūra. Polimerizacijos metu susidarantis polimeras suriša netirpias heksane iniciatoriaus daleles. Mažèjant iniciatoriaus koncentracijai polimerizacijos procesas lètèja. Sintezè nutraukiama suardžius iniciatoriaus kompleksą vandenilio chloridu. Susidarę tirpūs alkoholyje titano junginiai ir alkilaliuminis iš nuosedu išplaunami alkoholiu. Atskirtas iš dispersijos polimeras džiovinamas ir granuliuojamas, 
o tirpiklis regeneruojamas. Sintezės metu polimero molekulinè masė reguliuojama dedant ị reakcijos mišinį vandenilio.

„Philips" būdu polietilenas sintetinamas esant didesniam slègiui - 2,8-5 $\mathrm{MPa}$ ir aukštesnèje temperatūroje $-110-175^{\circ} \mathrm{C}$; iniciatorius yra $\mathrm{Cr}_{2} \mathrm{O}_{3}$ ir $\mathrm{Al}_{2} \mathrm{O}_{3}$; iniciatoriaus efektyvumas 3-10 g; polimero būsena - tirpalas cikloheksane; reakcijos trukmè 1,5 val. Susidaręs polietilenas tirpsta cikloheksane, todèl iniciatorius šalinamas karštą tirpalą centrifuguojant. Pašalinus iniciatoriaus likučius, tirpalas aušinamas iki temperatūros, kurioje susidaro ir nusèda polietileno dribsniai, kurie toliau plaunami, džiovinami ir granuliuojami. Tokiu būdu susintetinto polimero molekulinè masè priklauso nuo reakcijos temperatūros. Didinant reakcijos temperatūra, molekulinè masè mažèja (pvz., $175^{\circ} \mathrm{C}$ temperatūroje gaunama tik 25000 molekulinès masès polietilenas).

Polietileno sintezė „Unipol“ būdu atliekama eteno dujose. Polimeras sintetinamas nuolatinio veikimo reaktoriuje, kuriame kietame nešiklyje imobilizuotas iniciatorius ir dujinis monomeras maišomi pseudoverdančiajame sluoksnyje. Gaminant polietileną šiuo būdu, tirpiklių nenaudojama. Tirpiklių nereikia regeneruoti, o tai reiškia, kad gaminant energijos sąnaudos sumažeja keturis kartus.

Gaminiai iš $P E$. Iš paruoštų ikaitintų ir išlydytų i lydalą polietileno granuliu formuojami gaminiai. Lydalo temperatūra $140-180^{\circ} \mathrm{C}$. Jau pagamintas polietileno detales galima sujungti suvirinant 200 $250{ }^{\circ} \mathrm{C}$ temperatūroje arba sulydant karšto oro srove. Visų termoplastinių dirbinių, gaminamų ekstrudiniu būdu, gamybos technologija yra panaši. Principinè polietileno dirbinių gamybos technologinè schema pateikta 2.19 paveiksle.

Ekstrudiniu būdu taip pat gaminama apie $80 \%$ visų plèvelių. Principinè polietileno plèvelès gamybos ekstrudiniu būdu per plyši schema pateikta 2.20 paveiksle.

Gaminamos vienasluoksnès ir daugiasluoksnès plèvelès. Principinè triju sluoksnių polietileno plèvelès gamybos įrenginio schema pateikta 2.21 paveiksle. Didžiausi plèvelès kiekiai gaminami ekstrudiniu pūtimo būdu. Principinè polietileno plèvelès gamybos ekstru- 
diniu pūtimo būdu schema pateikta 2.22 paveiksle. Ekstruderyje išlydyta žaliava tempiama i viršų oro srauto, gaunant nenutrūkstamą dirbinị (rankovę), kuris neturi siūlių. Pagaminta plèvelè suvyniojama i ritinius.

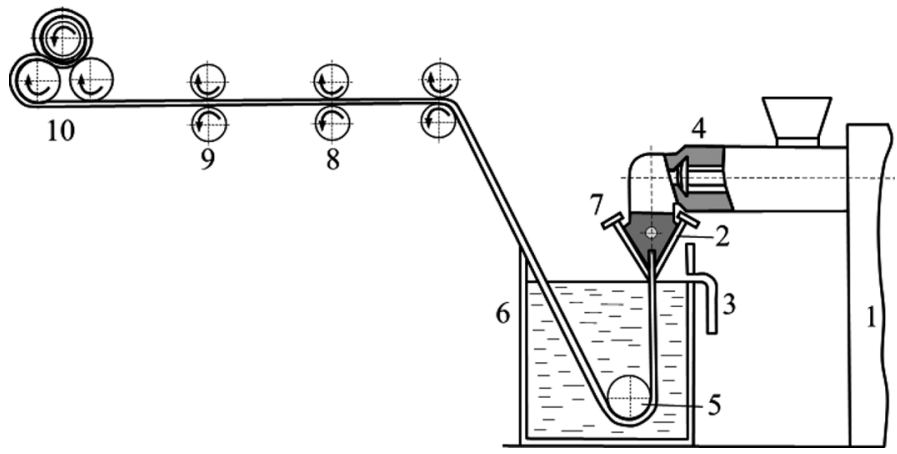

2.20 pav. Principinè polietileno plèvelès gamybos schema (ekstrudiniu būdu per plyši): 1 - ekstruderis; 2 - plyšio galvutė; 3 - perteklinio vandens nupylimo sistema; 4 - ekstruderio grotelès; 5 - pagrindinis volelis; 6 - aušinimo vonia; 7 - plyšio reguliatorius;

8 - kraštu apipjaustymo įrenginys; 9 - traukimo voleliai; 10 - susukimo įrenginys

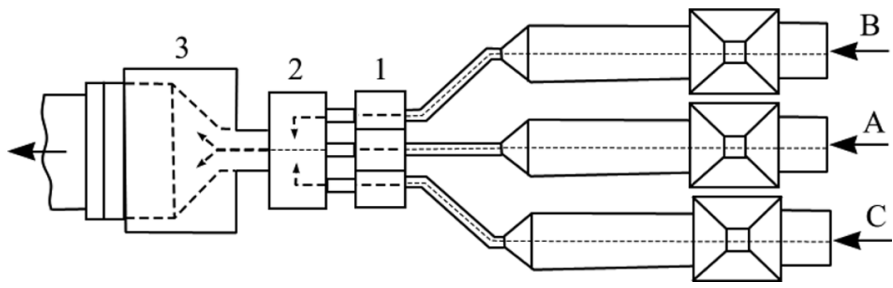

2.21 pav. Principinè trijų sluoksnių polietileno plèvelès gamybos irenginio schema: $\mathrm{B}$ - pirmojo sluoksnio ekstruderis; A - pagrindinio sluoksnio ekstruderis; C - antrojo sluoksnio ekstruderis; 1 - paskirstymo irenginys; 2 - adapteris; 3 - trijų sluoksnių plèvelès formavimo galvutė 


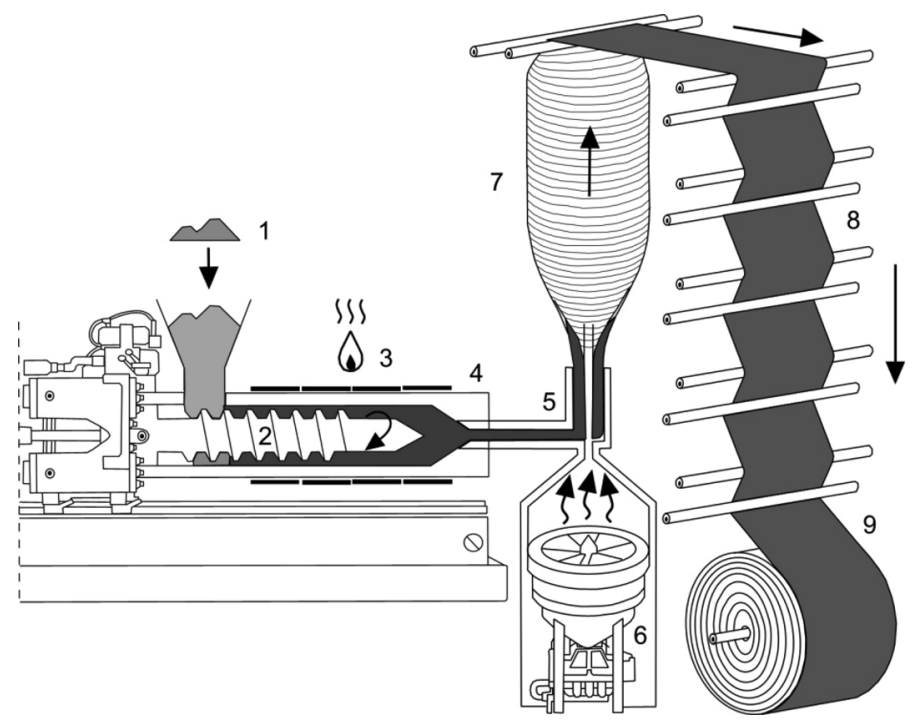

2.22 pav. Principinė polietileno plèvelès gamybos ekstrudiniu pūtimo būdu schema: 1 - plastiko granulès su priedais; 2 - stūmimo sraigtas; 3 - kaitinimo elementai; 4 - ekstruderio formavimo galvutès pradžia; 5 - kryptingai nukreipta ekstruderio galvutė; 6 - orapūtè; 7 - išpūstas plèvelès burbulas; 8 - išlyginimo volai; 9 - vyniojimo įrenginys

\subsubsection{Polietileno savybès}

Polietilenas yra termoplastinis, elastingas, nenuodingas polimeras, kuris sunkiai užsidega, o užsiliepsnojęs dega be suodžių. Kambario temperatūroje jis netirpsta nei viename iš buityje naudojamų tirpikliu, o šildomas ištirpsta benzene, chlorbenzene, trichloretane, tetrachlormetane, tuluene, alkane. PE brinksta angliavandeniliuose, jo neveikia rūgščių, druskų, šarmų tirpalai, jis laidus šviesai. Ilgai veikiamas ultravioletinès spinduliuotės polietilenas pradeda ją sugerti ir senti, o saulès šviesoje veikiant deguoniui oksiduojasi jo paviršinis sluoksnis. Oksidaciją galima sulètinti pridejjus antioksidantų arba užpildų (grafito ir suodžiu). Jonizuojančiosios spinduliuotès veikiamas polietilenas suyra: praranda elastingumą, mažeja stipris, skiriasi dujiniai skilimo produktai (vandenilis, metanas ir kt. dujos). 
Kad būtu geresnès savybès, polietilenas gali būti modifikuojamas (švitinamas arba veikiamas cheminèmis medžiagomis). Švitinant modifikuotas polietilenas tampa termiškai atsparesnis ir tinkamesnis putplasčiams arba izoliacinèms medžiagoms gaminti. Cheminiu būdu polietilenas modifikuojamas tirpinant tetrachlormetane. Chlorinto polietileno savybès labai skiriasi nuo pradinio polietileno savybių. Modifikuotas polietilenas, kuriame yra $30 \%$ chloro, tampa minkštesnis ir elastingesnis, $40-45 \%$ chloro padaro polietileną kieta, standžia, šilumos poveikiui atsparesnę medžiagą kuri gali būti naudojama karšto vandens vamzdžiams gaminti.

LDPE yra labiau pažeidžiamas oksidacijos procesų nei HDPE, nes amorfinès zonos oksiduojamos greičiau nei kristalinès. Taigi mažèjant PE tankiui jautrumas oksidacijai didèja. Taip pat tankị veikia ir polimeriniu grandinių šakotumas - kuo labiau šakotos grandinès, tuo gaunamas mažesnis PE tankis. Pavyzdžiui, jei 1000 grandinès dalių LDPE turi 21 metilo atšakas, jo tankis yra $0,922 \mathrm{~g} / \mathrm{cm}^{3}$, jei $43-0,916 \mathrm{~g} / \mathrm{cm}^{3}$. Maksimali LDPE naudojimo temperatūra $71^{\circ} \mathrm{C}$. LLDPE pagal tankị labiau panašus į LDPE, tačiau pagal makromolekulių grandinių geometrinę formą - i linijinį HDPE.

HDPE maksimali naudojimo temperatūra $82{ }^{\circ} \mathrm{C}$. HDPE yra stipresnis nei LDPE, tačiau jis labiau linkęs deformuotis - tai rodo didesnis medžiagos susitraukimas pereinant iš plastiškosios būsenos i kietaja. Tiek HDPE, tiek LDPE yra pakankamai atsparūs smūgiams, nors gaminiai, esant aukštam kristališkumo laipsniui HDPE, gali būti trapūs. HDPE yra stipresnis, tankesnis, kietesnis, atsparesnis dilimui nei LDPE. Didesnio tankio PE paprastai yra mažesnio valkšnumo nei mažesnio tankio polietilenas. HDPE laidumas dujoms yra gerokai mažesnis lyginant su LDPE, pavyzdžiui, laidumas azoto dujoms yra 1,4 HDPE ir 9,7 LDPE; helio dujoms 11 ir 47; deguonies dujoms 4 ir 29; anglies dioksidui 3,6 ir $126\left(\mathrm{~cm}^{3} \cdot \mathrm{mm}\right) /\left(\mathrm{cm}^{2} \cdot \mathrm{s} \cdot \mathrm{cmHg}\right)$, esant $25^{\circ} \mathrm{C}$ temperatūrai. Akivaizdu, kad mažiau atsparus oksidacijos procesams yra LDPE. Linijinès struktūros PE yra atsparesnis oksidacijai nei šakotos struktūros polimeras, turintis daugiau amorfinès fazės. 
UHMWPE yra linijinis kopolimeras, struktūriškai panašus i HDPE, tačiau jo vidutinè molekulinè mase yra 1-10 kartu didesnè nei standartinio HDPE.

\subsubsection{Gaminiai ir naudojimas}

Polietilenas naudojamas pakavimo medžiagoms gaminti, elektrotechnikoje (laidų ir kabelių izoliacija), chemijos pramonëje, buitinei technikai, iš jo gaminami vamzdžiai, irenginių detalès, ivvairios plèvelès. Statyboje ypač lengvos, nelaidžios vandeniui, stiprios daugiasluoksnès polietileno plèvelès naudojamos pastatu sienų, stogų grindu vandens garų izoliacijai. Tokių plèvelių nutraukimo jèga tempiant $(\mathrm{N} / 5 \mathrm{~cm})$ išilgai yra $170-450$, o skersai $-110-270$. Garinis laidis $\left(\mathrm{g} / \mathrm{m}^{2} / 24 \mathrm{~h} / 23{ }^{\circ} \mathrm{C}\right)-190$, atsparumas ultravioletinių spindulių poveikiui - 3 mèn., atsparumas temperatūros poveikiui - nuo -40 iki $+80^{\circ} \mathrm{C}$. Garui laidžios plèvelès naudojamos kaip pirminis dangos sluoksnis po stogo danga. Jos sudaro sąlygas drègmei išgaruoti iš stogo vidiniu pastato konstrukcijų apsaugo konstrukcijas nuo išorinio atmosferos poveikio. Storoji polietileno plèvelè iš išputintos medžiagos naudojama irengiant tarpaukštines betonines „plaukiojančias“ grindis. Tai paklotas iš išputinto LDPE su uždarų porų struktūra, specialiai sukurtas laminuotoms grindims, taip pat gali būti naudojamas ir klojant parketą. Tačiau naudojant šią plèvelę apsaugai nuo drégmès papildomai reikalinga ir paprasta polietileno plèvelè. Paklotas pasižymi gera šilumos ir garso izoliacija, tankis yra $20 \mathrm{~kg} / \mathrm{m}^{3}$, storis 2-12 mm; bekvapis, chemiškai inertiškas, netoksiškas, atsparus cheminèms medžiagoms; ilgą laiką atsparus ịspaudimams ir smūgiams.

Modifikuotas polietilenas (PEX) naudojamas karšto vandens vamzdžiams gaminti, kadangi modifikuotas polietilenas yra atsparus karšto vandens poveikiui.

Polietilenas (PE) yra moderni ir nekenksminga medžiaga, sèkmingai naudojama slèginiams vamzdžiams gaminti. Polietileno vamzdžiai naudojami įrengiant vandentiekio, dujotiekio ir nuoteku (dažniausiai slègio) sistemas, dažnai naudojami pramonèje. Dèl lankstumo, lengvumo ir ilgaamžiškumo polietilenas tapo pagrindine 
medžiaga renovuojant senus vandentiekio vamzdynus ar irengiant naujus pagal betranšèję technologiją. Plastikiniai PE, kaip ir kiti plastikiniai vamzdžiai, atsparūs cheminėms medžiagoms, jų šilumos laidumo koeficientas - 0,36-0,43 W/(m·K). Gaminami vienasluoksniai ir daugiasluoksniai PE vamzdžiai.

Iš polietileno gaminami ir kevalai vamzdžių apsaugai. Išpūsto polietileno kevalai naudojami visų tipų vamzdžių šiluminei izoliacijai. Jie mažina šiluminius nuostolius šildymo vamzdžiuose, neleidžia sušalti vandeniui šalto vandens vamzdynuose, apsaugo vamzdynus nuo mechaninių pažeidimų. Kevalai sujungiami kabėmis, klijais, lipnia juosta. Vidinis tokių kevalų skersmuo 15-108 mm, sienelès storis: $6,9,13,20 \mathrm{~mm}$.

Išpūsto polietileno gaminiai priskiriami šilumą izoliuojančių medžiagu grupei. Šios medžiagos šilumos laidumo koeficientas yra apie $0,04 \mathrm{~W} /(\mathrm{m} \cdot \mathrm{K})$. Pūsto polietileno gaminiai gali būti naudojami ten pat, kur ir polistireninio putplasčio ir poliuretano kevalai. Šią medžiaga patogu naudoti drègnose patalpose, nes neišskiria kenksmingų medžiagų. Tai lanksti, lengvai karpoma, klijuojama, netrupanti, nelūžtanti, lengvai perdirbama, nepaliekanti kenksmingu atliekų medžiaga. Gaminiai yra lengvai montuojami ir išardomi.

\subsection{Polipropilenas (PP)}

Šiandien polipropilenas (PP) yra plačiai naudojamas termoplastikas. Polipropilenas gali būti gaunamas izotaktinès, sindiotaktinès ir ataktinès struktūros. Stereoreguliarios polipropileno makromolekulès sintetinamos iš propeno, susidarančio naftos krekingo metu koordinacinès polimerizacijos būdu.

Pramoninè gamyba izotaktinio polipropileno koordinacinès polimerizacijos būdu pradèta $1957 \mathrm{~m}$. Italijoje, Vokietijoje ir JAV. Pagaminto polipropileno kokybė priklauso nuo iniciatoriaus.

Bendras polipropileno granulių vaizdas pateiktas 2.23 pav., a. Polipropileno dirbiniai yra perdirbami, ju indentifikavimo simbolis pateiktas 2.23 pav., b. 


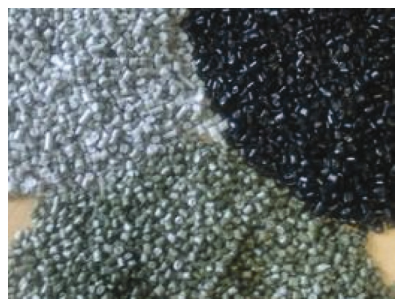

b

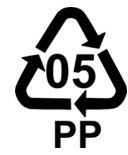

2.23 pav. Polipropileno granulès (bendras vaizdas) (a), polipropileno identifikavimo simbolis (b)

\subsubsection{Polipropileno žaliavos ir gamyba}

Polipropilenas (PP) gaminamas iš propeno, susidarančio naftos krekingo metu kaip eteno priemaiša. Koordinacinès polimerizacijos metu naudojant Ziegler ir Natta iniciatorius susidaro stereoreguliarusis izotaktinis polipropilenas ( 2.24 pav.). Jis turi visas termoplastikams būdingas savybes. Taip pat propenas gali būti polimerizuojamas radikaliniais ir katijoniniais būdais. Polimerizuojant propeną šiais būdais gaunami klampūs, lipnūs ir tiršti polimerai.

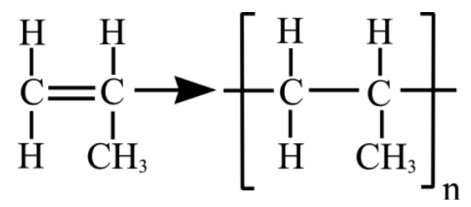

2.24 pav. Polipropileno gavimas iš propileno (propeno)

Polipropilenas gaunamas nuolatinio veikimo irenginyje. Nuolatinio veikimo polipropileno sintezès irenginys pateiktas 2.25 paveiksle.

Reaktoriuje iniciatoriais inicijuojama polimerizacija tirpale azoto terpèje vyksta $54-65^{\circ} \mathrm{C}$ temperatūroje ir esant 1,4-2,2 MPa slègiui. Iniciatorius iš talpyklos kartu su propeno srautu patenka $\mathfrak{i}$ reaktorių. Birus kietas polipropilenas patenka $\mathfrak{i}$ iškrovimo irengini. Nesureagavęs manometras ciklone išvalomas, filtruojamas, atvėsinamas aušintuve, suslegiamas kompresoriumi ir gražinamas i reaktorių. Tokiu būdu gaminamas pakankamai grynas polipropilenas. 


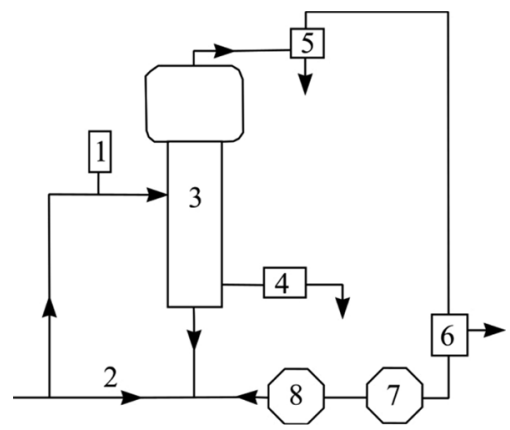

2.25 pav. Nuolatinio veikimo polipropileno sintezès irenginys:

1 - iniciatoriaus talpykla; 2 - propeno tiekimo vamzdis; 3 - reaktorius;

4 - polipropileno iškrovimo i̇renginys; 5 - ciklonas; 6 - propeno filtras;

7 - aušintuvas; 8 - kompresorius

Iš polipropileno granulių $250-300{ }^{\circ} \mathrm{C}$ temperatūroje yra formuojamas pluoštas ir plèvelès, liejami gaminiai, nes stabilizuotas polipropilenas nesuyra ir nekeičia savybių trumpą laiką kaitinant jo lydalą.

Principinè PP vamzdinių profilių gamybos technologinè schema pateikta 2.26 paveiksle.

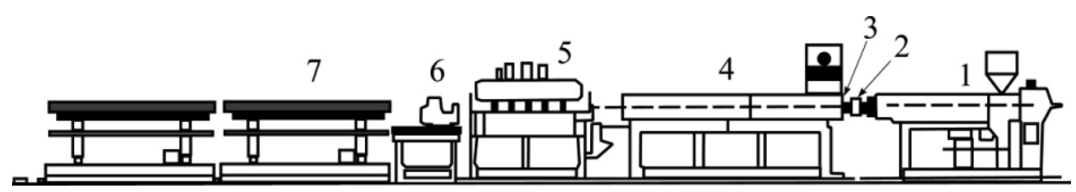

2.26 pav. Principinè vamzdinių profilių gamybos schema:

1 - ekstruderis; 2 - ekstruderio galvute; 3 - kalibravimo įrenginys;

4 - vakuuminè vonia; 5 - tempimo įrenginys; 6 - pjaustymo irenginys;

7 - prièmimo įrenginys

Statyboje dažnai naudojamos polipropileno plèvelès, kurios kontroliuoja garu kondensavimosi poveiki, vandens prasisunkimo greiti (geotekstilè, agrolèvelè). Principinè polipropileno plévelès gamybos schema pateikta 2.27 paveiksle. PP plèvelè gali būti gaminama ir kitais būdais. 


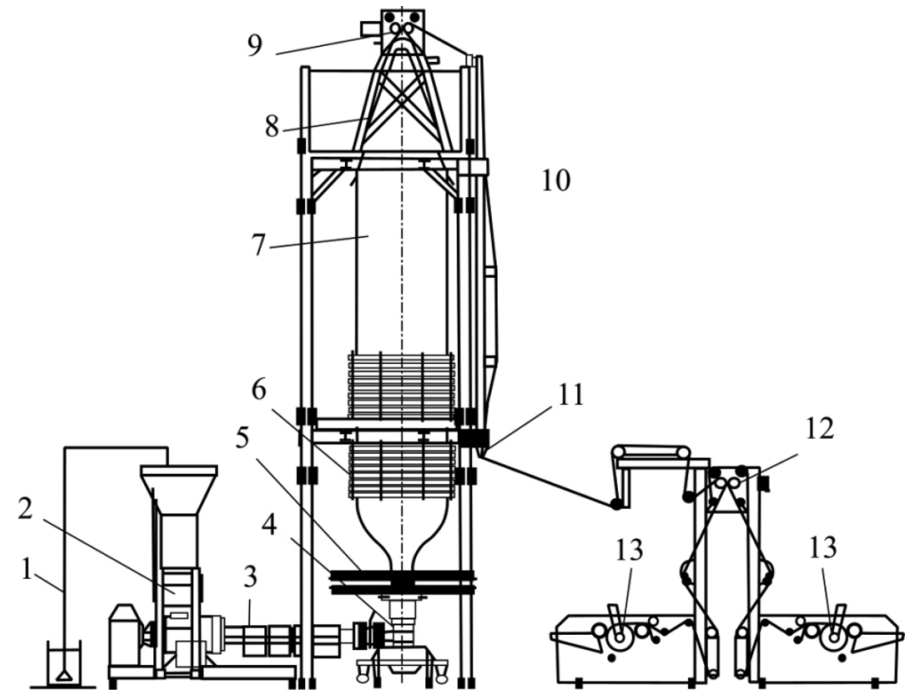

2.27 pav. Principinè polipropileno plèvelès gamybos schema rankovès būdu; 1 - pneumatinis krautuvas; 2 - bunkeris; 3 - ekstruderis; 4 - formavimo galvute; 5 - atšaldymo įrenginys; 6 - žiedinis kreiptuvas; 7 - plèvelès rankové; 8 - transportavimo įrenginys; 9 - tempimo įrenginys; 10 - plèvelé; 11 - velenai; 12 - pjaustymo irrenginys; 13 - velenas su plèvele

Taip pat iš polipropileno gaminamas polipropileno pluoštas (2.28 pav.), kuris naudojamas betonams ir skiediniams armuoti.

Polipropileno pluošto gamybos

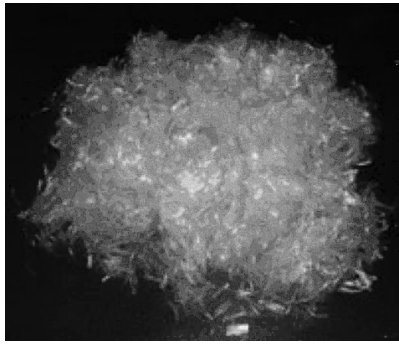

2.28 pav. Polipropileno pluoštas principinè schema pateikta 2.29 pav. Granulių arba miltelių pavidalo polipropilenas iš bunkerio dozuojamas $i$ lydymo galvutę ir nukreipiamas ant lydymo grotelių. Toliau dozavimo irenginys išlydytą polipropileną per filtrą tiekia i kamerą. Kameroje polipropileno siūlas aušinamas. Išeinantis iš kameros siūlas jau būna sukietèjęs, toliau jis patenka $i$ tempimo irengini, iš kurio išèjęs siūlas susukamas į ritę. 


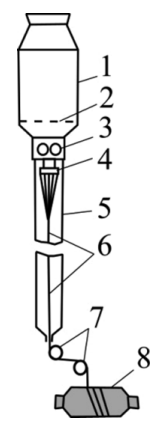

2.29 pav. Polipropileno pluošto principinè gamybos schema:

1 - lydymo galvute; 2 - lydymo grotelès; 3 - dozavimo îrenginys;

4 - filtras; 5 - kamera; 6 - siūlas; 7 - tempimo įrenginys; 8 -ritè

\subsubsection{Polipropileno savybès}

Pagrindinès polipropileno savybès pateiktos 1.2 lentelëje. Polipropilenas atsparus rūgščių ir šarmų poveikiui, kambario temperatūroje netirpsta chlorintuose angliavandeniliuose, benzene, toluene, pasižymi geromis izoliacinèmis savybèmis, yra pakankamai lengvas - jo tankis $900-930 \mathrm{~kg} / \mathrm{m}^{3}$.

PP mažiau atsparus oksidacinei destrukcijai nei polietilenas, jo oksidacija prasideda veikiant šviesai ir šilumai jau kambario temperatūroje. Dèl to, kad jis būtų atsparesnis deguonies ir šilumos poveikiui, i polipropileną dedama stabilizatorių. Pagrindinis polipropileno trūkumas yra aukšta stiklèjimo temperatūra $\left(-15^{\circ} \mathrm{C}\right)$. Atšaldytas iki žemesnès temperatūros jis tampa trapus. Modifikuoto polipropileno terminès savybės pagerejja. Modifikuotas polipropilenas vadinamas techniniu polipropilenu.

\subsubsection{Gaminiai ir jų naudojimas}

Iš polipropileno gaminamos plèvelès ir vamzdžiai, mašinų detalès, talpyklos, formuojamas pluoštas.

PP vamzdžiai skirti buitinèms, lietaus ir drenažo vandens nuotekoms transportuoti. Šie vamzdžiai taip pat gali būti naudojami 
pramoninėms nuotekoms transportuoti, pralaidoms po keliais, požeminių kabelių apsaugai.

Polipropileno vamzdžių skersmuo dažniausiai būna 110 $1000 \mathrm{~mm}$, standartinis vamzdžiu ilgis $6 \mathrm{~m}$, atsparumo klase $\mathrm{S}$ $\left(8 \mathrm{kN} / \mathrm{m}^{2}\right)$. Polipropileno vamzdžiai turi atitikti standarto LST EN 13476-1 keliamus reikalavimus.

Polipropileno plèvelès, naudojamos statyboje, būna vienasluoksnès ir daugiasluoksnès. Jos padeda kontroliuoti garų kondensavimosi procesą ir kondensato kaupimąsi. Naudojant PP plèvelę kondensatas nevirsta vandeniu, o kaupiasi plèvelèje, vèliau pakilus temperatūrai išsiskiria garų pavidalu. PP plèvelès yra pakankamai lengvos - apytiksliai $110 \mathrm{~g} / \mathrm{m}^{2}$, atsparumas plěšimui išilgai būna $>200 \mathrm{~N} / 5 \mathrm{~cm}$, skersai $->100 \mathrm{~N} / 5 \mathrm{~cm}$, garu pralaidumas (per $24 \mathrm{~h}$, kai temperatūra $23{ }^{\circ} \mathrm{C}-85 \%$ ) yra nuo $1500 \mathrm{~g} / \mathrm{m}^{2}$.

Polipropileninis pluoštas (dar vadinamas fibromis) yra stiprus ir elastingas, lengvas, atsparus cheminiams poveikiams. Toks pluoštas betono mišiniuose ir statybiniuose skiediniuose padeda išvengti ịvairių įtrūkimų, stabdo mikroplyšių formavimąsi, susidarančių plastiškai masei slūgstant, traukiantis, džiūstant, didina atsparumą smūgiams, laužimui, trinčiai.

Pluoštą rekomenduojama naudoti irengiant grindis pramonès imonèse, skiediniams, betoniniams blokams, tinkui ir kt. Atsižvelgiant i naudojimo sriti, gaminami ịvairaus ilgio pluoštai $-6,12,18$, $36,54 \mathrm{~mm}$.

Polipropileninis pluoštas dažnai naudojamos kiliminèms dangoms gaminti. Jis yra pakankamai tvirtas, atsparus devejjimui ir blukimui, neigeria vandens, chemiškai inertiškas, todèl sunkiai dažomas (ribotas spalvų pasirinkimas), bet dèl šios priežasties jame sunkiai susidaro dèmès.

Polipropilenas yra santykinai nebrangus pluoštas. Dažalai i polipropileno mišini patenka tik prieš ekstruziją t. y. verpalai nudažomi iki kilimo audimo ar gamybos kitais būdais. Dèl šios priežasties kiliminès dangos iš polipropileno ilgai išsaugo spalvas, nors jų spalvine gama ir nepasižymi įvairove. Polipropilenas atsparus purvui. Jis yra 


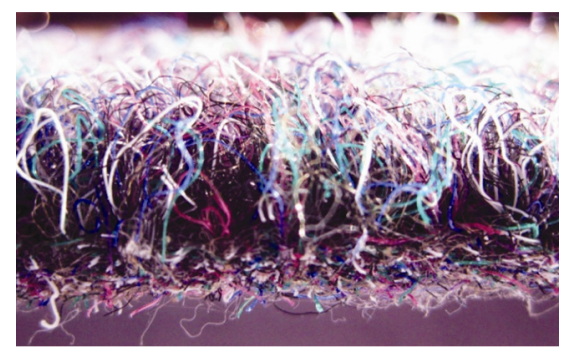

2.30 pav. Polipropileninė kiliminė danga

hidrofobinis ir nebijo medžiagų, kurių pagrindas - vanduo, bet riebalinès medžiagos jam yra pavojingos. Pluošto trūkumai: mažas atsparumas susidèvejimui ir ugniai. Polipropilenas lydosi $+165^{\circ} \mathrm{C}$ temperatūroje ir greitai susidèvi intensyviai naudojant. Kiliminès dangos iš polipropileno gali būti tiek kilpinès vieno ar kelių lygių (2.30 pav.), tiek ir pjauto pūko. Didelio žmonių susibūrimo vietose yra geriau naudoti polipropileninius kilimus, kuriose yra žemos vieno lygio kilpos. 


\section{REAKTOPLASTIKAI}

Reaktoplastikai gaminami iš termoreaktyviujų polimerų. Termoreaktyvusis polimeras yra toks, kurio lydalas šildomas chemiškai kinta ir sudaro kietą tinklinès struktūros produktą. Reaktoplastikai gamybos proceso metu pereina stadija, kuri vadinama kietinimu, t. y. molekulès surišamos i erdvini tinklą. Jeigu sukietinta medžiaga pašildoma, ji šiek tiek suminkštejja, tačiau jos jau neịmanoma išlydyti ar performuoti i kitą dirbini. Todèl šie plastikai aukštesnèse temperatūrose kiek geriau pakelia mechanines apkrovas ir kaitinami iki skilimo temperatūros išlieka kieti. Dirbiniai iš reaktoplastikų nekeičia formos iki $130{ }^{\circ} \mathrm{C}$ temperatūros (išskyrus uretaninius). Reaktoplastikai dažnai būna kaip sudètinis produktas, i kurio sudèti ieina armuojantieji priedai. GRP (ang. glass-reinforced plastic) - poliesteris su stiklo pluošto armatūra. GRP vamzdžiai naudojami visų matmenų pramoniniams technologiniams slèginiams ir savitakiams tinklams. Išorès jègų veikiamų reaktoplastikų deformacija būna tamprioji ir jie yra atsparūs smūginèms apkrovoms. Šių plastikų fizikinès-mechaninès savybès priklauso nuo cheminès sudèties, struktūros, laikymo ir naudojimo trukmès. Pagamintoje medžiagoje likusios aktyvios medžiagų grupès gali toliau reaguoti, dèl to po kurio laiko dirbinio savybès gali būti kitokios nei iš pradžių. Pagal procesus, vykstančius kietinimo metu, reaktoplastikai skirstomi i tris grupes: polikondensacinius reaktoplastikus, poliadicinius reaktoplastikus, polimerizacinius reaktoplastikus.

\subsection{Polikondensaciniai reaktoplastikai}

Polikondensaciniai reaktoplastikai gaminami iš termoreaktyvinès dervos, kuri kietinama virsta iš tinklinių makromolekulių sudarytu reaktoplastiku. Kietinimo metu atskyla mažamolekuliai reakcijos produktai (dažniausiai vanduo). Kietinimo metu vanduo nespejja išgaruoti ir gaminyje gali atsirasti akučių. Medžiagos akytumo galima išvengti i formavimo masę dedant absorbentų (medienos miltų), kurie kietinimo temperatūroje suriša iš klampios medžiagos masès nespejusi išgaruoti vandeni. 
Iš fenolformaldehidinių dervų (3.1 pav., a) - novolakų ir rezolių gaminami fenoplastikai (3.1 pav., b). Fenoplastikams gaminti naudojamas fenolio ir formaldehido monomeras, kuris yra pakankamai pigus. Fenolis gaunamas iš benzeno, formaldehidas - iš metano. Fenolformaldehidinès dervos cheminè formulè pateikta 3.1 pav.

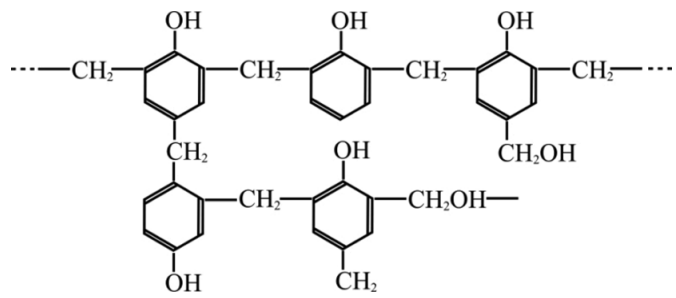

a

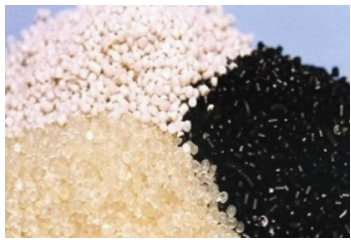

$\mathrm{b}$

3.1 pav. Fenolformaldehidinè derva (a), fenoplastikai (bendras vaizdas) (b)

Priklausomai nuo fenolio ir formaldehido santykio fenoplastikai skirstomi ị: rezolines dervas, novolakines dervas.

Rezolinès dervos sintetinamos iš fenolio ir formaldehido, esant formaldehido pertekliui (formaldehido ir fenolio santykis 6:5 arba 7:6), katalizatoriai - šarminių metalų hidroksidai, amoniakas, aminai. Rezolinès dervos kietinamos aukštesnèje temperatūroje, kurioje virsta fenoplastikais. Novolakines dervos gaunamos vykstant formaldehido ir fenolio polikondensacijai, esant fenolio pertekliui (fenolio ir formaldehido santykis 6:5 arba 7:6), katalizatoriai - druskos arba sieros rūgštis. Kai kurių dervų savybès pateiktos 3.1 lentelèje.

Fenoplastikai naudojami kompozitams, klijams ir lakams. Didžiausia fenoplastikų dalis naudojama kaip matrica kompozituose, armatūros vaidmeni atlieka kapotas stiklas, celiuliozè, sintetinis pluoštas, popierius, audinys. Armuoti naudojant popierių gaunamas sluoksniuotas kompozitas - getinaksas, naudojant audini - tekstolitas. Šie kompozitai gaminami popierių arba audini imirkant organiniame tirpiklyje ištirpintoje fenolformaldehidinejje dervoje, paskui medžiaga išdžiovinama ir supresuojama $160{ }^{\circ} \mathrm{C}$ temperatūroje, esant $10 \mathrm{MPa}$ slègiui. Fenoplastikai nelaidūs elektrai, atsparūs vandeniui, 
rūgščių tirpalams, tačiau neatsparūs šarmams. Formaldehidinių dervų gamybos metu susidaro atliekos, kurios sunkiai utilizuojamos, todèl šio tipo reaktoplastikų gamybos apimtys mažèja.

3.1 lentelè. Kai kurių dervų savybès ( $\mathrm{F}$ - fenolformaldehidinè derva, $\mathrm{E}$ epoksidiné derva, $\mathrm{Pe}$ - polieteriné derva, $\mathrm{Pa}$ - poliamidiné derva)

\begin{tabular}{|c|c|c|c|c|}
\hline \multirow[t]{2}{*}{ Savybès } & \multicolumn{4}{|c|}{ Derva } \\
\hline & $\mathrm{F}$ & $\mathrm{E}$ & $\mathrm{Pe}$ & $\mathrm{Pa}$ \\
\hline Tankis, $\mathrm{g} / \mathrm{cm}^{3}$ & $1,2-1,36$ & $1,1-1,4$ & $1,1-1,46$ & $1,2-1,45$ \\
\hline $\begin{array}{l}\text { Tamprumo modulis } \\
\text { tempiant, } \mathrm{GPa}\end{array}$ & $1,4-6,8$ & $1,9-5,0$ & $1,5-4,5$ & $3,2-5,5$ \\
\hline $\begin{array}{l}\text { Tempiamasis stipris, } \\
\mathrm{MPa}\end{array}$ & $22,5-78,3$ & $27,4-140$ & $23,5-68,5$ & $90-95$ \\
\hline $\begin{array}{l}\text { Temperatūrinès plètros } \\
\text { koeficientas, } \\
\times 10^{-6} \mathrm{~m} / \mathrm{m} /{ }^{\circ} \mathrm{C}\end{array}$ & $60-80$ & $48-80$ & $60-90$ & $50-58$ \\
\hline $\begin{array}{l}\text { Atsparumas šilumai } \\
\text { pagal Martensa, }{ }^{\circ} \mathrm{C}\end{array}$ & $140-180$ & $140-150$ & $60-80$ & $250-370$ \\
\hline $\begin{array}{l}\text { Susitraukimas kietė- } \\
\text { jant, \% }\end{array}$ & $0,5-7,0$ & $0,5-3,6$ & $4,0-15$ & $0,5-2,0$ \\
\hline $\begin{array}{l}\text { Vandens ịmirkis } \\
\text { (24 val.), \% }\end{array}$ & $0,15-0,6$ & $0,03-0,3$ & $0,15-0,6$ & $0,01-0,6$ \\
\hline $\begin{array}{l}\text { Šilumos laidumo } \\
\text { koeficientas, } \mathrm{W} /(\mathrm{m} \cdot \mathrm{K})\end{array}$ & $0,23-0,27$ & $0,17-0,21$ & $0,12-0,23$ & $0,35-0,37$ \\
\hline
\end{tabular}

Aminoplastikai (3.2 pav.) gaminami iš karbamidformaldehidiniu ir melaminformaldehidinių dervų, kurios gaminamos polikondensuojant formaldehidą su karbamidu arba su melaminu.

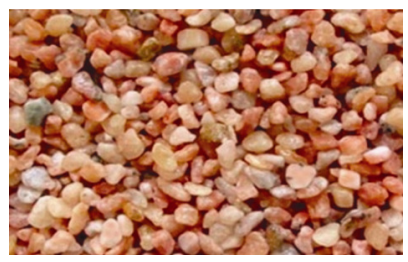

3.2 pav. Aminoplastikai (bendras vaizdas)

Šios dervos naudojamos kaip rišikliai gaminant presavimo miltelius, i kuriu sudèti gali įeiti celiuliozè arba kitas užpildas. Mišinys džiovinamas ir smulkinimas. Iš tokių miltelių karšto presavimo būdu, esant $140-170{ }^{\circ} \mathrm{C}$ temperatūrai, gaminami plastikiniai dirbiniai. Karbamidformaldehidinès dervos naudojamos 
sintetiniams klijams gaminti. Tokiais klijais karšto presavimo būdu yra sujungiami faneros sluoksniai. Aminoplastikai mažiau atsparūs vandeniui ir šilumai nei fenoplastikai, bet atsparesni šviesai. Apie 70 \% koncentracijos karbamidformaldehidinių dervų vandeniniai tirpalai naudojami kaip sintetiniai klijai. Klijavimo metu dervos gali būti kietinamos šaltojo (i klijus dedama kietinimo katalizatoriaus) ir karštojo (gaminant kompozitus - karštojo presavimo būdas) presavimo būdu. Iš aminoplastų gaminamos putos. Tai termoizoliacinè medžiaga, tinkama sienoje esančio oro tarpui užpildyti, taip pat ji tinka medinių apmūrytų namų sienoms šiltinti. Tokiu būdu šiltinant pastatą nepažeidžiama sienos konstrukcija ir apdaila, nes putos ipurškiamos per 16-18 mm skyles, igręžtas mūro siūlèse. Putos stingdamos nesiplečia ir neardo sienų. Putų tankis yra apie $13 \mathrm{~kg} / \mathrm{m}^{3}$, šilumos laidumo koeficientas $0,033 \mathrm{~W} /(\mathrm{m} \cdot \mathrm{K})$, gniuždymo stipris $-9 \mathrm{kPa}$, vandens garu laidumo koeficientas $-0,25 \mathrm{mg} /(\mathrm{m} \mathrm{h} \mathrm{Pa})$. Atsparios ugniai putos nepalaiko degimo proceso.

\subsection{Poliadiciniai reaktoplastikai}

Poliadiciniai reaktoplastikai skiriami i poliuretaninius ir epoksidinius reaktoplastikus.

Poliuretaniniu reaktoplastiku (PUR) žaliava - izocianatai ir alkoholiai. Poliuretanai labai atsparūs šviesai, rūgščių ir šarmų poveikiui. Iš šių poliuretaninių reaktoplastikų gaminami kietieji (55$\left.60 \mathrm{~kg} / \mathrm{m}^{3}\right)$ ir minkštieji $\left(25-40 \mathrm{~kg} / \mathrm{m}^{3}\right)$ putplasčiai. Akyta kietojo putplasčio struktūra suformuojama naudojant porodari (pvz., freoną $\left(\mathrm{CFCl}_{3}\right)$. Minkštieji putplasčiai putinami anglies dioksido dujomis.

Poliuretaniniais putplasčiais izoliuojamos didelio tūrio talpyklos, sandarinamos ertmès montuojant duris ir langus. Poliuretaniniai mišiniai naudojami trinčiai atsparioms dangoms - metalui, stiklui, keramikai, medienai, plastikams. Tokie mišiniai naudojami medžiagoms klijuoti, jie patogūs, nes suriša detalių paviršiuje esantị vandeni ir stipriai sujungia medžiagas. 
Principinè statybinių poliuretano plokščių gamybos schema pateikta 3.3 paveiksle.

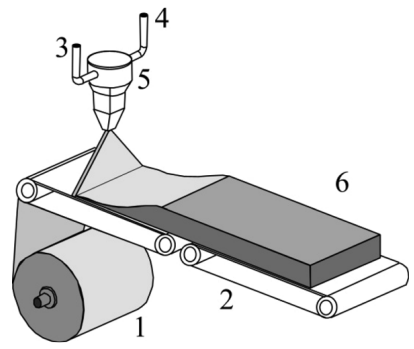

3.3 pav. Statybinių poliuretano plokščiu gamybos principinè schema:

1 - popierius; 2 - juostinis transporteris; 3 - monomeras;

4 -katalizatorius; 5 - maišyklè; 6 - išsipūtusios poliuretano plokštès

Poliuretano putos - termoizoliacinè ir garso izoliacinè medžiaga, pasižyminti geromis šilumos izoliavimo savybėmis. Poliuretano putos puikiai kimba prie visų paviršių, gerai išlaiko užpurkštą formą, užpildo visus įtrūkimus, atsparios mechaninèms apkrovoms ir deformacijoms. Jų naudojimo laikas pakankamai ilgas, didelè šilumos varža. Poliuretano putos nepūva ir nepelija, jose negyvena graužikai. Poliuretano putų kietejjimo pradžia $30 \mathrm{~min}$, o pabaiga 24 val., ilgaamžiškumas 15 metų. Tačiau ilgaamžiškumo charakteristika priklauso nuo naudojimo sąlygu, jos neatsparios ultravioletiniams saulès spinduliams ir drègmei. Dèl to putas, naudojamas langams ir durims istatyti, reikia apsaugoti nuo aplinkos poveikio ir iš pastato vidaus, ir iš išorès. Apsaugai naudojamos juostos, tinkas, dažai, apvadai. Tinkamiausia putų naudojimo statybvietèje temperatūra $20-22{ }^{\circ} \mathrm{C}$, santykinis oro drègnis $60-65 \%$. Kuo didesnis yra santykinis oro drègnis, tuo daugiau putų susiformuoja.

Pagrindiniai putų komponentai: monomeras ir dujos (naudojamos ozono sluoksnio neardančios medžiagos). Kartu su dujomis iš balionèlio išpurškiamas monomeras. Polimerizacijos procesas vyksta dèl reakcijos su aplinkos drègme.

Varijuojant komponentų sudèti ir technologijos procesa, galima gauti labai skirtingų savybių putu poliuretaną. Pagrindiniai veiksniai, 
turintys įtakos putų poliuretano savybèms, yra tikslus pradinių komponentų dozavimas ir efektyvus permaišymas.

Priklausomai nuo savybiuc, putos gali būti specialios ir universalios, jos gali skirtis tankiu, tamprumu, elastingumu, vandens imirkiu, plèvelès ant paviršiaus sudarymo geba, gniuždymo ir tempimo stipriu, defomuojamumu. Tačiau pagrindinis montažinių putų skirtumas yra šis: jos gali būti vienkomponentès ir dvikomponentès. Populiariausios vienkomponentès montažinès putos iš poliuretano yra tos, kurių didelis išsiplètimo koeficientas. Dvikomponentès montažinès putos gaunamos sumaišius medžiagas iš dviejų balionèlio rezervuarų. Medžiagu aktyvumui sužadinti pakanka pasukti specialią judamą dali, esančią ant putų balionèlio. Šios dvikomponentès putos beveik nesiplečia ir sukietejja per 5-10 minučių. Vienkomponenčių putų kietejjimo pradžia 30 min., o pabaiga 24 val. Statant langus ir duris dvikomponentès putos kaip ankeriai naudojamos todèl, kad jos praktiškai nekeičia pradinio tūrio, dèl to rèmuose nesusidaro lenkimo itempių, dèl kurių rèmai gali išlinkti. Užtvirtinus rèmą visa kita erdvė gali būti užpildoma vienkomponentèmis putomis. Pastaruoju metu montažinès putos naudojamos kaip tvirtinanti medžiaga montuojant akrilines vonias ar ant apatinès skardinès vonios pusès sudarant termoizoliacini sluoksni. Statyboje putos naudojamos kanalizacijos vamzdžiams ir požeminèms šachtoms hermetizuoti, elektros ịrangai montuoti, sieninėms termoizoliacinèms plokštėms, stogo dangai, čerpèms, vamzdynams jungti, sieninèms plokščių siūlèms užtaisyti, langams ir durims bei palangèms istatyti.

Dabar gaminamos ir specialios putos, kurios atsparios vandeniui, dirvos rūgštingumui, bakterijoms, pelèsiams. Jos naudojamos betoninių šulinių žiedų tarpams hermetizuoti. Gali būti gaminamos ir kaitrai atsparios putos, kurios nepraleidžia dūmų. Jų atsparumas kaitrai - 10-20 min. Putas, skirtas darbams žiema, galima naudoti esant minusinèms temperatūroms ir nedideliam santykiniam drègniui.

Tačiau ne visais atvejais ši medžiaga naudojama pagal paskirti, dažnai statyboje visi iki vieno plyšiai būna užtaisomi montažinėmis putomis. 
Epoksidiniai reaktoplastikai (EP) gaunami kietinant kietikliais epoksidines dervas. Kietinimo metu nesusidaro mažamolekulių junginių, nesikeičia kietinamos dervos tūris, derva gerai sukimba su pluoštais, metalais, stiklu, keramika. Šios dervos naudojamos universaliems klijams, dangoms, pluoštiniams ir sluoksniuotiems kompozitams gaminti. Epoksidiniai reaktoplastikai naudojami aukštos kokybès dirbiniams gaminti, nes yra brangesni ir pakankamai ilgai kietinami šaltuoju būdu. I tokius dirbinius kartu su kietikliais ir aktyviais skiedikliais dedama elastingumą ir atsparumą smūginèms apkrovoms didinančių priedų. Pagaminti dirbiniai yra stiprūs ir termiškai stabilūs, nedegūs, jie naudojami presavimo formoms, mašinų detalèms gaminti.

Statybos pramoneje visuomeninès paskirties pastatuose iš epoksidinių dervų dažnai formuojamos plastikinès dangos. Epoksidinès dangos dengiamos ant betono, suformuojant atsparią dilimui ir aplinkos poveikiams grindų danga. Norint padidinti epoksidinio sluoksnio stiprį i epoksidinę dervą dedama užpildu - kvarcinių smèlių, kuriu grūdelių skersmuo $0,3-0,6 \mathrm{~mm}$.

Nuo epoksidinių dervų klampos priklauso formuojamos dangos paskirtis. Mažos klampos dervomis imirkomos betoninès grindys. Taip apdorotos grindys tampa stipresnès, atsparesnès dilimui, cheminèms medžiagoms, sumažinamas senų betoninių grindų dulkètumas. Naudojant tokias dervas ant paviršiaus nesusidaro epoksido sluoksnio - visa derva susigeria i betono poras. Mažos klampos epoksidinès dervos gali būti naudojamos grindims prieš padengiant didesnès klampos dervomis. Prieš dengiant epoksidinèmis dangomis paviršius pašiurkštinamas suslègto vandens srove arba naudojant smèliasrovę. Epoksidinès dangos ant švaraus ir suremontuoto paviršiaus tepamos teptuku, voleliu arba šepečiu. Pagrindo drègnumas neturi viršyti $4 \%$. Jei epoksidinė derva prieš dengimą skiedžiama vandeniu, pagrindo drègnumas gali būti $8 \%$. Dengiama dviem sluoksniais: pirmasis sluoksnis skirtas poroms užpildyti, esant ypač poringam pagrindui, kuriam naudojamos mažos klampos impregnuojančios epoksidinès dervos, antrajam sluoksniui naudojamos didesnès klampos dervos. 
Užpildai beriami ant dar nesukietėjusios suformuotos dangos. Dangai sukietejus, šepečiu nušluojami silpnai besilaikantys užpildai. Suformuotas paviršius gaunamas šiurkštus.

\subsection{Polimerizaciniai reaktoplastikai}

Iš šių plastikų gaunami dviejų tipų gaminiai: skaidrus optinis reaktoplastikas ir kietosios poliesterinès dangos. Skaidraus optinio reaktoplastiko optinès savybès nesiskiria nuo polimetilmetakrilato savybių, tačiau jis yra 40 kartų kietesnis.

Poliesterinès dervos naudojamos dangoms, kietinamoms bedeguoneje aplinkoje. Didžiausias poliesterinių dervų kiekis naudojamas kompozitu poliesteriniams stiklaplasčiams gaminti, iš kuriu gaminami vamzdžiai, talpyklos ir ivaairios detalès. Kompozitai yra hidrofobiniai, nelaidūs šilumai, elektrai, nekeičia savybiu iki $60^{\circ} \mathrm{C}$ temperatūros, atsparūs smūginèms apkrovoms

Poliesterinès dervos gaunamos polikondensuojant ịvairius alkoholius ir rūgštis. Jos gali būti termoplastinès ir termoreaktyviosios. Tai priklauso nuo polikondensacijos reakcijoje dalyvaujančiu alkoholių molekulių struktūros. Dervos tankis yra $1,19 \mathrm{~g} / \mathrm{cm}^{3}$; lenkimo stipris - $130 \mathrm{MPa}$; tamprumo modulis - $3650 \mathrm{MPa}$; tempimo stipris $-70 \mathrm{MPa}$; susitraukimas džiūstant $-7-8 \%$.

Dirbinių iš sintetinių dervų pagrindas yra natūralios mineralinès medžiagos, pavyzdžiui, kvarcas, bazaltas ir granitas. Šios uolienos yra surišamos su sintetine derva. Kaip priedai naudojami dervos kietikliai, kietejjimo reakcijos stabilizatoriai, katalizatoriai, plastifikatoriai ir kiti.

Poliesterio pluoštas naudojamas kiliminèms dangoms gaminti. Pirmą kartą poliesteriniai pluoštai kilimams gaminti buvo panaudoti septintajame dešimtmetyje. Pagal atsparumą nusidèvejjimui šie pluoštai gerokai atsilieka nuo poliamido. Pluoštas vizualiai yra panašus i vilna. Priklausomai nuo priedų, poliesteris gali būti blizgantis arba matinis. Poliesteriniai pluoštai ypač tinka patogioms kiliminių dangu rūšims, kurių pūkų masè gali būti reguliuojama. 


\section{KOMPOZITINĖS POLIMERINĖS MEDŽIAGOS IR DIRBINIAI}

Polimerinėmis kompozitinėmis medžiagomis vadinamos visos medžiagos, kurios sudarytos bent iš dviejų fiziškai ar vizualiai išskiriamų komponentu. Taigi kompozitais laikomos mikro- ar makrolygiu iš kelių medžiagų sudarytos medžiagos. Naudojant kompozitines medžiagas ir konstrukcijas, galima padidinti gaminio stipri, sumažinti atskiru gaminio elementų ir viso gaminio svorị, taip pat konstrukcijų skerspjūvio matmenis, pagerinti gaminio termoizoliacines ir akustines savybes. Atitinkamai išdèstant konstrukcijos sluoksnius, galima maksimaliai išnaudoti visas geriausias medžiagu savybes, sumažinti konstrukcijų, i kurias remiasi arba prie kuriu tvirtinamos kompozitinès konstrukcijos, laikomaja galią ir gamybai naudojamos energijos, transportavimo bei montavimo išlaidas. Tačiau didžiausias kompozitų pranašumas yra labai palankus jų svorio ir sąlyginio standumo ar stiprio santykis.

Polimerinèse kompozitinėse medžiagose kaip matricos dažniausiai naudojamos ivairios dervos ar termoplastiniai polimerai. Matrica yra rišamoji medžiaga, kuri apkrovą perduoda armuojančiajai medžiagai ir saugo ją nuo įvairių neigiamų aplinkos poveikių. Parenkant matricos medžiaga, reikia atsižvelgti i tai, kokia temperatūra veiks kompozita eksploatacijos metu. Taip pat matrica eksploatacijos metu turi būti nejautri dujoms ar skysčiams, su kuriais jai gali tekti kontaktuoti. Konstrukciniams kompozitams geriausiai tinka termoreaktyviosios dervos: polieterinès, cianoesterinès, fenolinès, poliimidinès, epoksidinès, poliesterinès, vinilo esterio dervos. Prie kompozitinių taip pat priskiriamos sluoksniuotosios medžiagos (laminatai), armuotosiosios medžiagos, taip pat medžiagos, užpildytos įvairaus dydžio dalelèmis - užpildais. Polimerinių kompozitinių gaminiu savybės labai priklauso nuo užpildų. Kaip užpildai gali būti: neorganinès mineralinès medžiagos, pavyzdžiui, stiklas, metalas, taip pat organinès medžiagos. Medžiagos gali būti granulių, plokštelių, pluošto ar audinio pavidalo. Užpildai pagal tai, ar keičia polimero 
mechanines savybes, skirstomi į neaktyviuosius ir aktyviuosius. Neaktyvieji užpildai nedidina medžiagos stiprio. Jie dažniausiai naudojami norint taupyti pagrindinę matricos medžiagą. Aktyviujjų užpildų dalelès yra asimetriškos formos, jų tampros modulis dažniausiai būna didesnis už polimerinès medžiagos tampros moduli. Kitas polimerinių kompozitinių medžiagu klasifikavimo kriterijus yra pagal armuojančiąsias medžiagas. Gali būti armuojama: stiklo pluoštu, anglies pluoštu, aramidiniu pluoštu, boro pluoštu.

\subsection{Daugiasluoksnès plokštès (,sendvič“ tipo)}

Kompleksiniai gaminiai - daugiasluoksnès statybinès plokštès (, sendvič “ plokštès), gaminamos iš lengvų medžiagų, susidedančių iš dviejų išorinių apsauginių sluoksnių ir termoizoliacinio vidinio sluoksnio. Išoriniai sluoksniai gali būti gaminami iš aliuminio, plieno, plastmasès, medienos drožlių plokštės; vidinis sluoksnis - iš putų poliuretano, polistireninio putplasčio, mineralinès vatos (4.1 pav.). „Sendvič“ plokštès pasižymi: gera termoizoliacija ir garso izoliacija, antikorozinėmis savybėmis, mažu drėgmès igeriamumu, atsparumu ugniai, technologiškumu, montavimo paprastumu, montavimo greičiu, estetišku išoriniu vaizdu (išorinès apdailos ir spalvos gausiu pasirinki$\mathrm{mu}$ ). Šios plokštès gali būti montuojamos gamybinèse ir administracinèse patalpose, prekybos centruose, sporto ir kituose kompleksuose, baseinuose, kuro kolonėlèse, plovyklose, oro uostu pastatuose, terminaluose, sandèliuose, medicininès paskirties patalpose, šaldymo kamerose, taip pat iš jų gali būti irengiamos vidinès pertvaros.

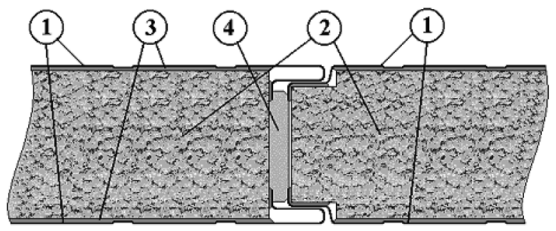

4.1 pav. „Sendvič̌“ plokštès sujungimas (bendras vaizdas):

1 - išorinis sluoksnis; 2 - vidinis sluoksnis; 3 - poliuretano klijai;

4 - poliuretano tarpinè 
Šiu gaminių išorinis sluoksnis dažniausiai gaminamas iš šaltai valcuoto, karštai cinkuoto plonasienio plieno lakšto. Gamybai naudojamas $0,5-0,7 \mathrm{~mm}$ plienas su įvairių tipų polimeriniais padengimais.

„Sendvič“ plokštés gali būti gaminamos dviem metodais: nenutrūkstamuoju ir periodiniu. Principine „sendvičc“ plokščiu nenutrūkstamojo būdo gamybos schema pateikta 4.2 pav. Gamyba nenutrūkstamuoju metodu sudaro trys pagrindiniai technologiniai barai. Pirmasis iš jų skirtas išoriniams sluoksniams ir jų paketams paruošti ant konvejerio. Nuvalytas ir paruoštas naudojamos medžiagos lakštas dedamas ant transporterio juostos ir padengiamas klijais. Tuomet ant jo dedamas atitinkamų matmenu paruoštas vidinis plokštès sluoksnis. Jeigu plokšte suprojektuota su kraštuose esančiu išoriniu rèmu arba standumo briaunomis, tai pagal visą perimetrą ar tarpuose dedami rémo elementai (aliuminio, medienos, faneros ir pan.). Toliau judant transporteriui, ant vidinio sluoksnio ir kitų elementų viršaus tepami klijai ir dedamas viršutinis sluoksnis. Jeigu reikia, tarp vieno iš

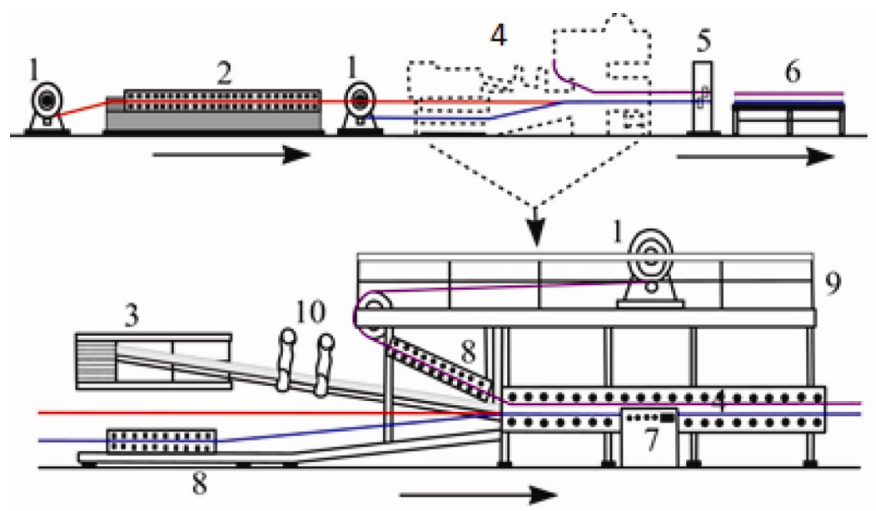

4.2 pav. Principinè „,sendvič“ plokščių gaminimo nenutrūkstamuoju būdu schema: 1 - išvyniojimo irenginys; 2 - valcavimo irenginys; 3 - vidinio sluoksnio tiekimo ịrenginys; 4 - presavimo ir kaitinimo kamera;

5 - plokštės pjaustymo ịrenginys; 6 - plokštès prièmimo ịrenginys;

7 - automatinio reguliavimo sistema; 8 - sujungimo mechanizmų išpjovimo irenginys; 9 - darbine platforma virš presavimo ir kaitinimo kameros; 10 - frezavimo įrenginys; 11 - viršutinio ir apatinio sluoksnių pjaustymo irenginys (pvz., metalo pjaustymo įrenginys) 
išorinių ir vidinio sluoksnio gali būti dedamas hidroizoliacinis sluoksnis, iš abiejų pusių apteptas klijais.

Kitas technologinès linijos baras - tunelinio tipo (25-30 m ilgio) kamera, kurioje plokščiu, judančių transporteriu, sluoksniai supresuojami ir kaitinami. Presuojama volais per tarpa judant plokštei, o kaitinama dažniausiai spiraliniais kaitintuvais. Be to, iš kaloriferio yra pučiamas ikaitintas oras. Temperatūra kameroje iš pradžių būna $+40{ }^{\circ} \mathrm{C}$, vèliau $+60{ }^{\circ} \mathrm{C}$, proceso pabaigoje iki $+80^{\circ} \mathrm{C}$. Transporterio judejimo greitis $0,6-1,8 \mathrm{~m} / \mathrm{min}$. (tai priklauso nuo gaminamos konstrukcijos storio, išorinių sluoksnių ir klijų tipo). Konstrukcijų ilgis, priklausomai nuo linijos ir kameros ilgio, gali būti įvairus (dažniausiai 6-8 m). Konstrukcijos, išejjusios iš presavimo ir kaitinimo kameros, patenka i trečiaji barą - tai apipjaustymo ir kartu profiliavimo baras. Jei rėmas yra medinis arba jo visai nèra, tai specialiomis frezomis gali būti išpjaustomi specialūs profiliai plokštems sujungti ir siūlèms sandarinti.

Jei yra poreikis, paviršiui apdoroti gali būti naudojamas ir ketvirtasis baras. Paviršius dengiamas antikorozinėmis plèvelèmis (dažais), atsparumą gaisrui didinančiomis dangomis ir kt. Lengvųu sluoksniuotujų konstrukcijų su storesniais išoriniais sluoksniais gamyba periodiniu metodu apima daugiau, bet smulkesnių barų: lakštų karpymo, ruošimo (nuvalymo), klijų užtepimo, konstrukcijos elementų surinkimo, gamybos baigiamujų etapų.

Paruošti lakštai perkeliami i paviršiaus ruošimo skyrių. Paviršiai nuvalomi, nudažomi, padengiami antikorozinemis dangomis ar kitaip apdorojami. Tada išgręžiamos skylès, paruošiami visi rèminimo elementai, (jei reikia) jie sujungiami, profiliuojami ir perduodami i surinkimo barą. Klijuojama dažniausiai epoksidiniais klijais. Suklijuoti lakštai dedami i specialų presa, kurio plokštumos yra kaitinamos. Metalinių plokščiu polimerinis padengimas suteikia pagrindines medžiagos savybes: išorini vaizda, atsparumą išorès poveikiui, ilgaamžiškumą. Kiekvienam objektui parenkamas tam tikras padengimo tipas, atsižvelgiant i klimatines ir eksploatacines sąlygas, taip pat išoriniam vaizdui keliamus reikalavimus. 
Termoizoliacija iš abieju pusiu yra apsaugota profiliuota cinkuota plienine skarda. Tvirtą trijų sluoksnių sujungimą suteikia aukštos kokybès klijai. Termoizoliacinio sluoksnio plaušeliai, išdèstyti skersine kryptimi, gerai suklijuoti su išoriniais sluoksniais, leidžia visą kompozitą nagrinèti kaip vientisą masę ir tai labai padidina plokštès stiprumą ir standumą. Šias plokštes galima montuoti ant metalinio, gelžbetoninio, medinio karkaso. Taip pat gaminamos sienų ir stogo plokštės. Dèl didelio plokščių atsparumo gniuždymui ir lengvumo, pastatui reikalingas mažas atraminių sijų skaičius ir būna spartesnis montavimas. Pati plokšte yra šiuolaikinis gaminys, nes yra santykinai lengvas, greitai montuojamas, pasižymi didele šilumine varža, atsparumu ugniai, ilgaamžiškumu ir spalvų ịvairove. Išardžius pastata, plokštès gali būti naudojamos antrą kartą.

\subsection{Dirbiniai iš medienos ir plastiko kompozitu}

Medienos ir plastiko kompozito, dar kitaip vadinamo WPC, (angl. wood-plastic composite), pagrindinès sudedamosios dalys yra medienos atliekos ir termoplastikai. Iš medienos atliekų naudojamos šios: medienos drožlès, miltai, pjuvenos, dulkès (gali būti naudojamos žemès ūkio augalų liekanos). Šiems kompozitams naudojami termoplastikai: polipropilenas (PP), polietilenas (PE), polivinilchloridas (PVC). WPC medžiaga buvo pradèta kurti dar 1960 metais. Iš šios medžiagos gaminamos lentos, kurios naudojamos išorèje - fasaduose, terasose, irengiant lieptelius, laiptu pakopas, tvoras, suoliukus, jas galima naudoti kaip langų, durų apvadus. Ši medžiaga savybèmis pranoksta natūralios medienos gaminius ar gaminius iš plastikų su chemogeninès kilmès užpildais. Gaminiai iš šios medžiagos nereikalauja jokios papildomos priežiūros eksploatacijos metu, taip pat jie gali būti perdirbami. Ši medžiaga neskilinejja, nepūva, neblunka.

WPC medžiagas apibūdinantis standartas - LST CEN/TS 15534-2 „Medienos ir plastikų kompozitai (WPC). 2 dalis. WPC medžiagų apibūdinimas“. WPC dirbiniams gaminti tinka termoplastikai, kurių formavimo temperatūra yra iki $200^{\circ} \mathrm{C}$. Organiniai užpil- 
dai WPC sudaro 50-70 \% produkto. Papildomai gali būti naudojami mineraliniai užpildai: kalcio karbonatas, talkas (steatitas), kaolinitinis molis, žèrutis (mica), stiklo pluoštas, taip pat priedai: plastifikatoriai ir stabilizatoriai. WPC gamyba sudaryta iš šių etapų: žaliavu paruošimo; žaliavu mišinio sumaišymo ir išlydymo; aušinimo; mechaninio apdirbimo; gaminio formavimo ir aušinimo.

Gaminant WPC žaliavos pirmiausia sumaišomos tarpusavyje, padaromas medžiagų mišinys. Maišymo metu imaišoma užpildo ir priedų. Priklausomai nuo gaminio paskirties, žaliavos dozuojamos taip: $30-70 \%$ sudaro medienos atliekos, 5-50 \% - polimeriné medžiaga, 0-15\% - priedai. Gaminant WPC dažniausiai naudojami priedai: lubrikantai, pigmentai, antioksidantai, UV-stabilizatoriai, antipirenai, antimikrobinès medžiagos. Mišinys gali būti iš karto kaitinamas ir formuojamas i dirbini arba daromos granulès, skirtos apdoroti toliau (4.3 pav.).

a

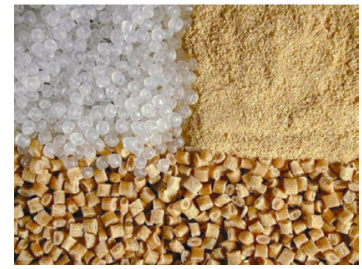

b

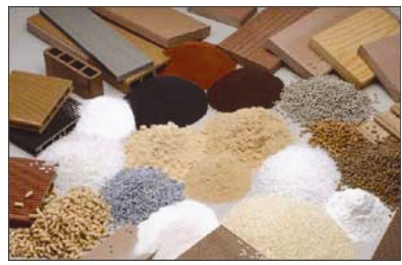

4.3 pav. Medienos ir plastiko kompozito žaliavos ir dirbiniai:

a - viršutinèje dalyje kairèje - polimero granulès, dešinèje - medienos atliekos ir apačioje - suformuotu granulių iš WPC vaizdas; $b$ - gaminiai

iš medienos ir plastiko kompozito ir suformuotos granulès

Kai iš karto formuojami dirbiniai, gamintojai išlydytą masę formuoja ekstruderiu. Suformuota ištisinè dirbinio juosta aušinama ir pjaustoma i norimo ilgio dirbinius. Kai pirma formuojamos granulès, tai ekstruderiu formuojamas ne ištisinis dirbinys, o ištisinès juostelès, kurios ataušintos sukapojamos. Tokiu būdu gautos granulès gali būti tiekiamos kitiems perdirbejjams, kurie gamina norimos formos dirbinius. 
Gaminant medienos ir plastiko kompozitą pagrindinis įrenginys yra ekstruderis. Jame esančiomis pilnavidurèmis ir tuščiavidurėmis formomis formuojami gaminiai. Pagrindinis ekstruderio uždavinys išlydytą polimerą sumaišyti su organiniu užpildu ir kitais priedais ir formavimo galvute suteikti jam formą. Principine ekstruderio schema pateikta 4.4 pav.

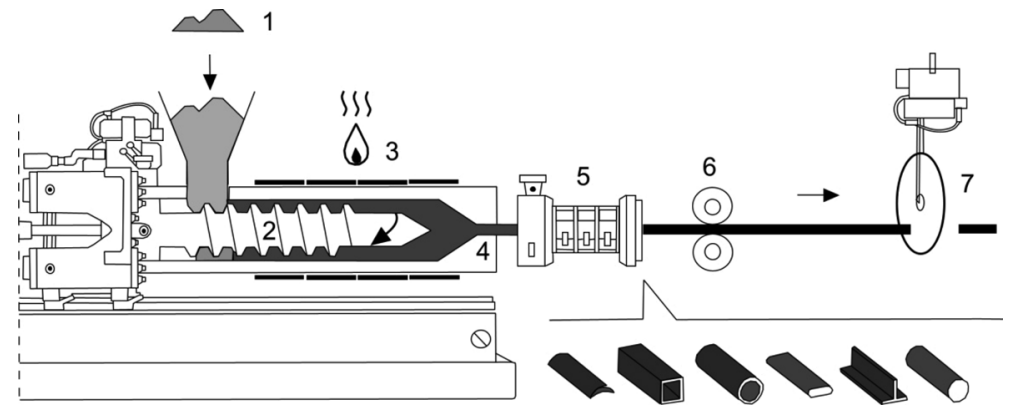

4.4 pav. Principinè ekstrudinès linijos, naudojamos plastikams gaminti, schema: 1 - plastiko granulès su priedais; 2 - stūmimo sraigtas;

3 - kaitinimo elementai; 4 - formavimo galvutè; 5 - aušinimo irenginiai; 6 - tempimo ir žymèjimo įrenginiai; 7 - pjaustymo įrenginiai

Gamyboje naudojami keli ekstruderių tipai: vienasraigtis ir dvisraigtis. Kai gaminama iš paruoštų granulių, naudojamas viensraigtis ekstruderis; kai gaminama iš polimerų ir medienos mišinio, dažniausiai naudojamas dvisraigtis ekstruderis. Taip pat galimas ir dvipakopis formavimas - vienas ekstruderis maišo mišini, o kitas ji profiliuoja. Organinis užpildas gali būti džiovinamas prieš mišinio paruošimą arba pirmajame ekstruderyje dvipakopio formavimo metu.

Principinė medienos ir plastiko kompozito gamybos technologinè schema pateikta 4.5 paveiksle.

WPC gaminant iš polietileno (WPC-PE) dažniausiai naudojamas didelès molekulinès masès polietilenas (HDPE), kurio tankis $960 \mathrm{~kg} / \mathrm{m}^{3}$. Dirbiniai, kuriems gaminti naudojamas šis polimeras, yra minkštesni, todèl juos lengviau pjauti, i juos lengviau sukti varžtus, tačiau jų lenkimo ir gniuždymo stipris yra mažesnis, taip pat jie pasi- 
žymi mažesniu atsparumu dilimui. Polietilenas yra atsparus cheminių medžiagu poveikiui, iskaitant ir stipriąsias rūgštis (sieros, druskos, azoto).

WPC gaminių, kurie gaminami naudojant polipropileną, (WPCPP) yra mažai, jie sudaro tik apie $10 \%$ rinkos. Polipropileno savybès yra pranašesnès už polietileno. Jis lengvesnis, stipresnis, stangresnis, jo slidumas mažesnis, taip pat mažesnis ir atsparumas dilimui. WPCPP yra ganėtinai kietas, todèl ji sunku tvirtinti vinimis ar varžtais. Jie montuojami specialiomis tvirtinimo kabemis ar specialiomis sistemomis. Taip pat WPC-PP yra daug sunkiau pjauti lyginant su WPC-PE.

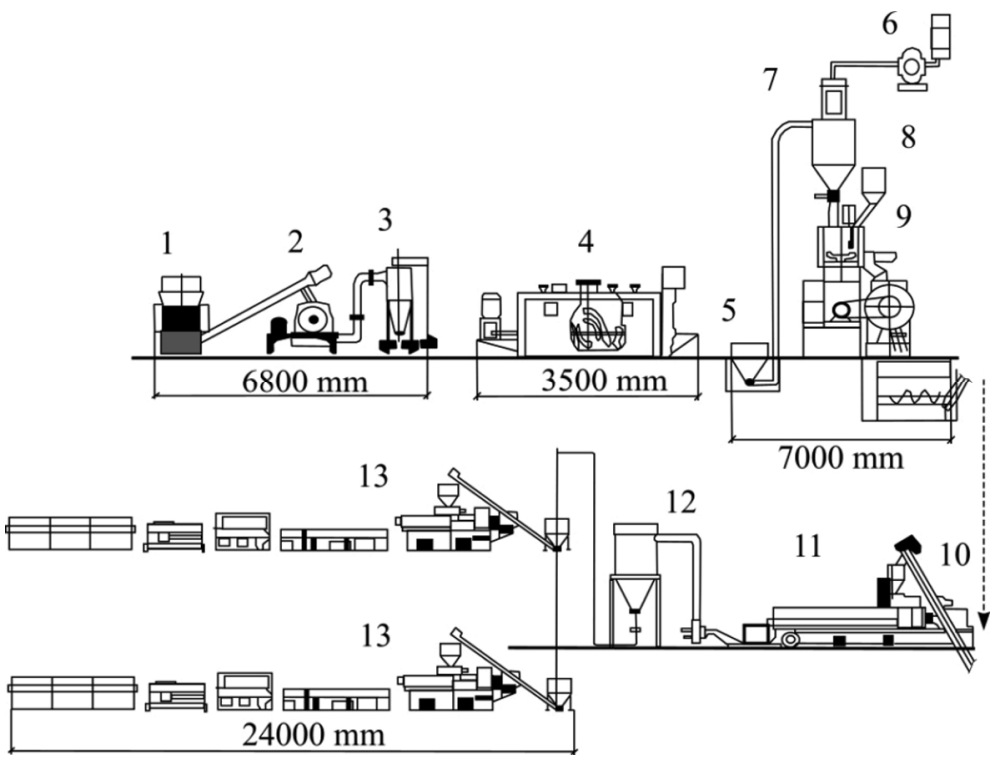

4.5 pav. Medienos ir plastiko gaminių principinè technologinė kompozito gamybos schema: 1 -medienos trupinimas; 2 -medienos malimas; 3 - medienos dulkių atskyrimas, 4 - medienos džiovinimas;

5 - paruoštos medienos sandèliavimas; 6,7 - oro valymo sistema; 8 - vakuumine talpykla; 9 - masès maišymas; 10 - masès transportavimas;

11 - medienos ir plastiko masés granulių ekstruderis; 12 -medienos ir plastiko granulių saugykla; 13 - gaminių iš medienos ir plastiko granulių formavimo ekstrudinè linija 
Polipropilenas yra labiau linkęs oksiduotis, taigi reikia gerokai didesnio kiekio antioksidantu ir stabilizatorių negu PE. Gaminiai iš WPC-PE ir WPC-PP yra degūs. Šių kompozitu degumui sumažinti taikomi du būdai: įterpiami degumą mažinantys priedai arba kompozitas gaminamas, naudojant polivinilchloridą.

WPC produktu, kurie pagaminti iš PVC medžiagos (WPC-PVC), rinkoje yra mažesnè dalis, negu pagamintų iš polipropileno. WPC terasinių lentu, pagamintų PVC pagrindu, rinkoje yra apie $11 \%$. Didžiausias PVC privalumas yra tas, kad jis yra labai atsparus degimui. Tačiau degdamas šis plastikas išskiria kenksmingas dujas, dèl to gaminant turi būti naudojami antipirenai bromo aliuminio ar magnio pagrindu. Dažniausiai medienos ir plastikų kompozitams gaminti naudojamas užpildas - medienos miltai. Medienos miltu piltinis tankis yra $0,1-$ $0,3 \mathrm{~g} / \mathrm{cm}^{3}$, savitasis tankis $-1,3-1,4 \mathrm{~g} / \mathrm{cm}^{3}$. Medienos miltai gaunami iš medienos atraižų ir medienos atliekų. Iš jų turi būti išvalyta žievè ir kitos medienai nebūdingos priemaišos. Dažniausiai naudojami pušies, klevo ar ažuolo medienos miltai. Medienos miltai ruošiami trupinant didesnes medienos daleles plaktukiniu trupintuvu ar kitais smulkinimo irenginiais. Medienos miltai skirstomi $\mathfrak{i}$ frakcijas vibraciniu ar rotaciniu būdu. Naudojamų medienos miltų dalelių dydis yra 180-425 $\mu \mathrm{m}$. Paprastai medienos miltai yra 4-8\% drègmès. Ši drègmè prieš gaminant kompozito dirbinius turi būti pašalinta.

Iš medienos ir plastiku kompozito (WPC-PE, WPC-PP, WPCPVC) gaminamos lentos (4.6 pav.), kurios naudojamos išorejje - fasaduose, terasose, irengiant lieptelius, laiptų pakopas, tvoras, suoliukus, jas galima naudoti kaip langų, durų apvadus (4.7 pav.). Ši medžiaga savybèmis pranoksta natūralios medienos gaminius ar gaminius iš plastikų su chemogeninès kilmès užpildais. Gaminiai iš šios medžiagos nereikalauja jokios papildomos priežiūros eksploatacijos metu, taip pat ji yra visiškai perdirbama.

Iš WPC gaminamiems langu rẻmams nereikia armuojančiujų elementų kaip remams iš polivinilchlorido. Sienos plokštès ir grindụ dangos iš WPC pasižymi geromis eksploatacinèmis savybèmis: gali atlaikyti nuo $-60 \mathrm{iki}+80{ }^{\circ} \mathrm{C}$ temperatūra, atsparios mechaniniams 


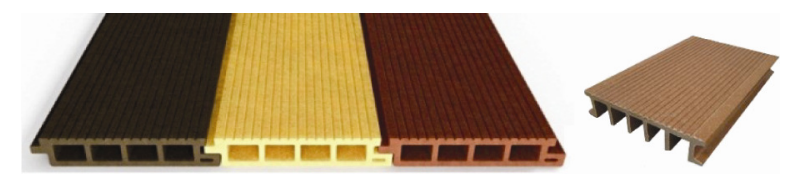

4.6 pav. Gaminių pavyzdžiai iš medienos ir plastikų kompozito - lauko terasos grindų lentos

a

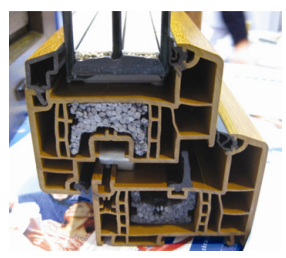

b

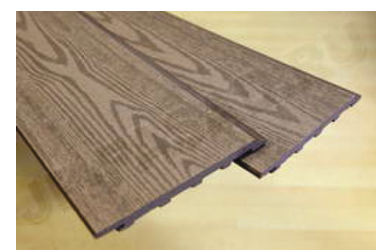

4.7 pav. Gaminių pavyzdžiai iš medienos ir plastikų kompozito: $a$ - lango rèmas (pjūvis); $b$ - sienų plokštès

pažeidimams, ultravioletiniams spinduliams, drègmei, vandeniui, senejjimui, nepūva, paprastai montuojamos.

Vienas iš aptariamų kompozitų senejjimo požymių yra suirimai, atsiradę dèl oksidacijos poveikio. Dèl oksidacijos poveikio iš pradžių gaminiuose atsiranda pirmieji smulkūs įtrūkimai ir gaminiai praranda spalvą. Vykstant senejjimo procesams įtrūkimai plečiasi ir po kiek laiko susiformuoja visas įtrūkių tinklas. Tam, kad gaminiai kuo ilgiau būtų apsaugoti nuo kenksmingų veiksnių - ultravioletinių saulès spindulių, deguonies, teršalų, drègmès, reikia, kad gaminant kompozitus būtų naudojamas reikiamas antioksidantų kiekis ir būtų tinkamai parinktas pats antioksidantas. Oksidacijos iniciatoriai - kenksmingi aplinkos poveikiai - šią medžiagą veikia taip, kad plastikas, esantis kompozite, suyra ir praranda vientisuma, o irimo metu gautos atskiros dalelès - užpildai neturi medienos ir plastiko kompozitui būdingų savybių. Kiti veiksniai, galintys pagreitinti kompozito irimą, yra masès perkaitinimas gamybos metu, per didesnis masès poringumas ir metalo oksidai, galintys patekti i formavimo masę.

Norint padidinti kompozitu atsparumą heterotrofiniams mikroorganizmams, gali būti dedama biocidinių ir kitų priedų, užkertančių 
kelią jiems vystytis. Taip pat norint išvengti šių organizmų veiklos padarinių naudojami tik sausi užpildai, o kompozitas turi būti tankus, su kuo mažiau porų ir tuštumų.

\subsection{Sluoksniuotieji gaminiai iš plastikų}

Šie dirbiniai gaminami iš popieriaus (kartono), išmirkyto sintetinėse karbamido ar fenolformaldehido dervose. Viršutiniams sluoksniams gali būti naudojamas baltintas, spalvotas arba išmargintas ivairiais raštais kartonas.

Sluoksniuotuju gaminių gamyba susideda iš šių pagrindinių etapų: popieriaus (kartono) išmirkymas sintetinèse dervose (principinè išmirkimo schema pateikta 4.8 paveiksle); lakštų surinkimas ir presavimas; lakštų pjaustymas (kartais šlifavimas).

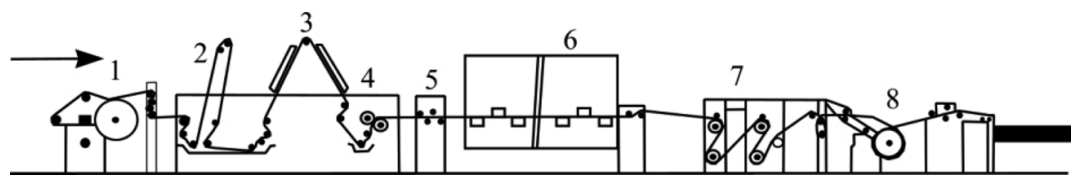

4.8 pav. Sluoksniuotujų gaminių iš plastikų mirkymo linija:

1 - popieriaus išvyniojimo įrenginys; 2 - pirminis mirkymas;

3 - tarpinis džiovinimas; 4 - antrinis mirkymas; 5 - dozatorius;

6 - džiovinimo įrenginys; 7 - vėsinimo valcai;

8 - lakštų vyniojimas arba nupjovimas

Pagal gamybos technologiją sluoksniuotuosius gaminius galima suskirstyti i tokias grupes: gamyba esant mažam slègiui arba nuolatinio presavimo (CPL - angl. continuously pressed laminate) (4.9 pav.); gamyba esant dideliam slègiui (HPL - angl. high pressure laminate).

Kartonas mirkomas mirkymo irenginyje, t. y. atviroje vonioje arba autoklave $(0,4-0,8 \mathrm{MPa})$. Išmirkytas kartonas patenka i džiovinimo kamera, kurioje džiovinamas karštu oru. Džiovinama iki $90{ }^{\circ} \mathrm{C}$ temperatūroje. Išdžiovintas kartonas vyniojamas ant būgno ir pjaustomas i lakštus. Iš kelių lakštų formuojami paketai, kurie dedami i presą ir suspaudžiami tarp nerūdijančiojo plieno poliruotų lakštų. 

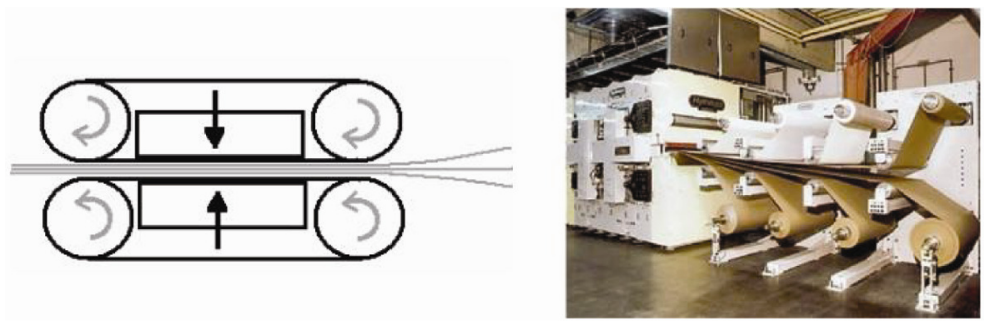

4.9 pav. Lakštų suspaudimas juostiniu presu (nuolatinio presavimo gamybos procesas, kompanija „Hymmen“)

Presavimo slègis yra 10-11 MPa (gaminama esant dideliam slègiui - iki $15 \mathrm{MPa}$ ) ir $150{ }^{\circ} \mathrm{C}$ temperatūra. Plastiko kietëjimo trukmè 45 minutès vienam lakšto storio milimetrui. Sukietejusio lakšto kraštai apipjaunami. Lakštu matmenys: ilgis 1000-5000 mm, plotis 600$1600 \mathrm{~mm}$, storis $1-5 \mathrm{~mm}$; tankis $1,4 \mathrm{~g} / \mathrm{cm}^{3}$, gniuždymo stipris 140 $160 \mathrm{MPa}$, tempimo stipris 90-130 $\mathrm{MPa}$, lenkimo stipris apie $100 \mathrm{MPa}$. Tokie sluoksniuotieji plastikai atsparūs silpnoms rūgštims ir šarmams.

Šiuo metu fasadinių sluoksniuotų gaminių iš plastikų rinkoje aktyvias pozicijas užima HPL plokštès (4.10 pav.) (lietuviškai - DSL „didelio slègio apdailos laminatai“"). Šiu plokščių svarbios charakteristikos yra atsparumas atmosferos poveikiui ir ultravioletiniams saulès spinduliams.

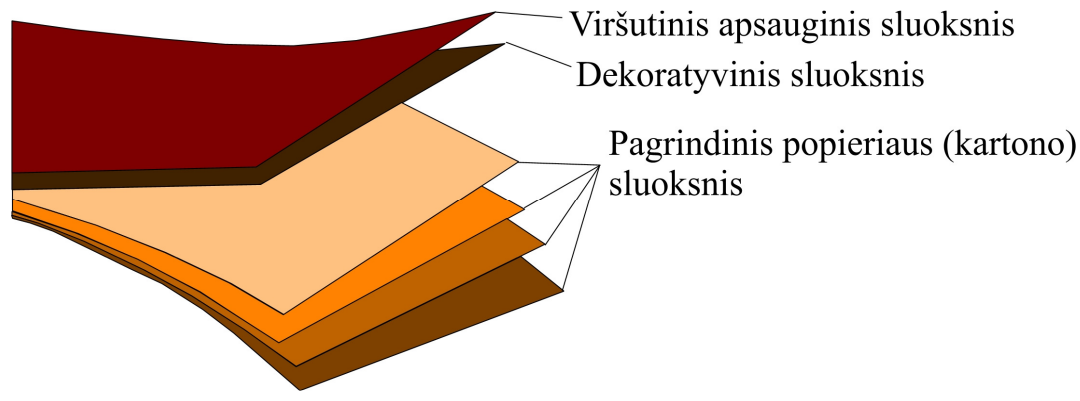

4.10 pav. Sluoksniuotasis gaminys (bendras vaizdas) 
Pagal standartą EN 438-1 „Didelio slègio apdailos laminatai“ HPL fasadu plokštès klasifikuojamos pagal EDF tipo bandymus. E žymuo reiškia, kad plokštes skirtos fasadui, D - plokštes ypač atsparios atmosferos poveikiui, o F - nedegios. Ypač atspariu HPL plokščiu atsparumas atmosferos poveikiui deklaruojamas pagal EN ISO 4892-2 standarta „Plastics - Methods of exposure to laboratory light sources Part 2: Xenon-arc lamps“. Šios plokštės bandomos imituojant visus imanomus atmosferos poveikius 3000 valandu̧, o tai teoriškai atitinka 50 eksploatavimo metu. Atlikus bandymus pagal minètą standarta plokštès, atsižvelgiant ị spalvos kontrasto skalę, skirstomos ị lygius (iš viso yra 5 spalvos kontrasto lygiai). Pateiksime pavyzdi: po 3000 valandų bandymų, atliktų klimatineje kameroje, nustatyta, kad plokštès atitinka 5-aji spalvų kontrasto skalès lygi. Šio lygio atitikmuo leidžia teigti, kad bandinys po 3000 valandų trukmès bandymo, kaip patvirtinta praktiniais tyrimais, apimančio 50 metu eksploatavimo perioda, t. y. intensyvaus aplinkos poveikio - karščio, šalčio, sniego, lietaus, saulès ir t. t. taikyma, ir nauja, tik ką pagaminta tokios pat spalvos plokšte, lyginant su bandomaja, vizualiai spalvos atžvilgiu nesiskirs. 4 lygis reiškia, kad spalvų skirtumas bus nedidelis, 3 lygis išsyk matomas ir žymus, 2 ir 1 lygis reiškia, kad po 50 metu plokštès bus išblukusios, sueižèjusios, turès kitų pažaidų. Standarto EN ISO 4892-2 reikalavimai yra labai griežti. Tie gamintojai ar produkto pardavejai, kurie plokščiu atsparumą aplinkos poveikiui nurodo pagal EN ISO 4892-2 ir EN ISO 4892-3 (Plastics - Methods of exposure to laboratory light sources - Part 3: Fluorescent UV lamps) reikalavimus, užtikrina net 4 spalvos kontrasto lygio plokštès kokybę ir tai, kad ji neturès pažaidų ir spalvos skirtumo daugiau kaip 50 metų. Pagal paminètą standartą EN ISO 4892-3 nurodomas atsparumas ultravioletiniu spalvų poveikiui reiškia, kad plokščių, 1500 valandų bandytu klimatinejje kameroje, paviršius turi būti apžiūrimas ir pažaidos klasifikuojamos i 5 lygius spalvų kontrasto skaleje. HPL plokščių tankis $1,45 \mathrm{~g} / \mathrm{cm}^{3}$, lenkimo stipris $\geq 90 \mathrm{MPa}$, tempimo stipris $\geq 80 \mathrm{MPa}$, tamprumo modulis $\geq 9500 \mathrm{MPa}$, šilumos laidumo koeficientas $0,3 \mathrm{~W} /(\mathrm{m} \cdot \mathrm{K})$, temperatūrinio plètimosi koeficientas $18 \cdot 10^{-6} 1 / \mathrm{K}$. 


\subsection{Polimerbetonis}

Polimerbetonis yra dirbtinè medžiaga, pradèta plačiai naudoti maždaug prieš 40 metų. Polimerbetonis yra betonas, kurio rišiklis polimeras. Naudojami polimerai - stireno lateksas, polivinilas ir kitos vandenyje tirpios polimerinès (epoksidinès) dervos. Šiam betonui gaminti naudojami mineraliniai užpildai (kvarcas, bazaltas, granitas, marmuras) ir smulkiadispersiai užpildai, tokie kaip talkas, aerosilas, maltas kvarcas, granito skaldele ir kt. (4.11 pav.).

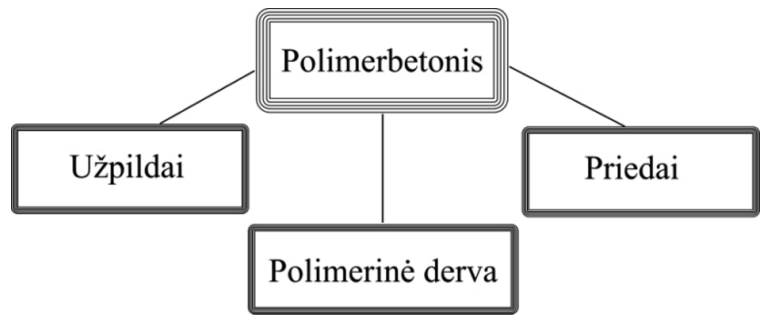

4.11 pav. Polimerbetonio sudètinès dalys

Šiam betonui būdingas didesnis tempimo stipris, mažesnis trapumas, geresnès deformacinès savybès. Polimerbetonis nelaidus vandeniui, pasižymi didesniu atsparumu šalčiui ir atsparumu dilumui, yra atsparus regresyviems skysčiams ir dujoms.

Polimerbetonio ir tradicinio C 25/30 klasés betono kai kurios savybès pateiktos 4.1 lenteleje.

4.1 lentelè. Polimerbetonio ir tradicinio C $25 / 30$ klasès betono kai kurių savybių palyginimas

\begin{tabular}{l|c|c}
\hline \multicolumn{1}{c|}{ Savybès } & Polimerbetonis & Betonas C 25/30 klasės \\
\hline Gniuždymo stipris, MPa & $80-110$ & $25 / 30$ \\
\hline $\begin{array}{l}\text { Tempimo stipris, nustatomas } \\
\text { lenkiant bandinius, MPa }\end{array}$ & $22-35$ & $2-4$ \\
\hline $\begin{array}{l}\text { Tempimo stipris, nustatomas } \\
\text { skeliant bandinius, MPa }\end{array}$ & $8-12$ & $1,5-2$ \\
\hline Atsparumas dilumui & $0,1-0,2$ & 0,6 \\
\hline Igeriamumas, \% & 0 & $4-8$ \\
\hline
\end{tabular}




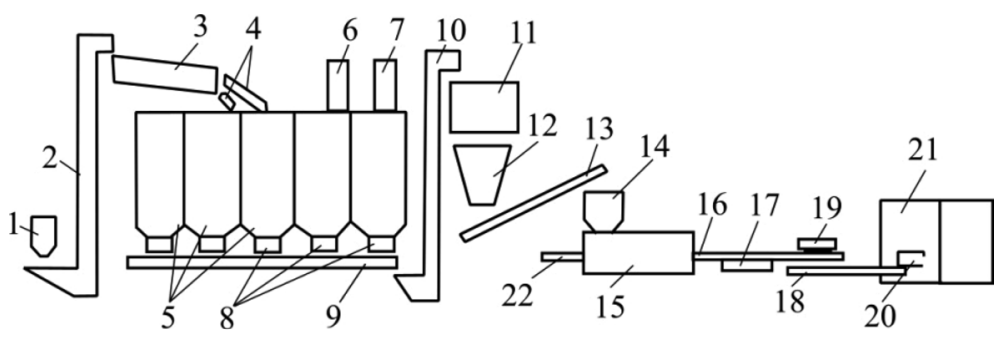

4.12 pav. Principinè polimerbetonio gamybos schema: 1 - žaliavų bunkeris; 2, 6, 7 - elevatorius; 3 - frakcionavimo įrenginys; 4 - pasvirę loveliai; $5,12,14$ - bunkeris; 8 - nuolatinio veikimo dozatorius; 9 - juostinis transporteris; 10 - prièmimo bunkeris; 11 - nuolatinio veikimo maišytuvas; 13 - pasviras transporteris; 15 - maišymo įrenginys; 16,18 - konvejeris; 17 - vibracinis stalas; 19 - išformavimo irenginys; 20 - klotuvai; 21 - sandèliavimo vieta; 22 - polimerinių dervų ir kitų priedų tiekimo vamzdis

Dèl didelio atsparumo rūgštims ir šarmams gaminiai iš polimerbetonio naudojami lietaus šalinimo sistemos detalèms gaminti, drenažo sistemoms įrengti. Principinė polimerbetonio gamybos schema pateikta 4.12 paveiksle.

Gaminant polimerbetoni žaliavos vežamos automobilių transportu. Užpildai vežami sunkvežimiais, kuriuose krovinys turi būti apdengtas, kad neišsibarstytų smulkūs, birūs užpildai. Derva transportuojama cisternose. Polimerbetonio žaliavai taikoma nuolatinè kokybès kontrolè. Užpildai yra džiovinami, frakcionuojami ir modifikuojamas jų paviršius (jei reikia). Užpildai pagal frakcijas dedami i skirtingus bunkerius, iš kurių elevatoriumi tiekiami i frakcionavimo irengini. Paskui paruošta žaliava dozuojama dozatoriais ant juostinio transporterio. Dozuojamų frakcijų kiekis priklauso nuo to, koks reikalingas mišinio užpildymas užpildo grūdeliais.

Nuo juostinio transporterio žaliava patenka į elevatorių, kuris ją suberia i sauso maišymo maišyklę. Sauso maišymo maišyklè sumaišo skirtingų dydžių daleles, kad sumaišytas su derva mišinys neišsisluoksniuotų. Iš sauso maišymo maišyklès užpildai patenka i kitą maišyklę, i kurią tiekiamas reikalingas kiekis poliesterinės dervos ir priedų. I maišymo įrengini tiekiamos iki maždaug $50^{\circ} \mathrm{C}$ temperatū- 
ros pašildytos polimerinès dervos ir kiti priedai (kietikiai, greitikliai, katalizatoriai, spalvą suteikiantys priedai). Polimerbetonio mišinys paprastai ruošiamas nuolatinio maišymo maišytuvuose tol, kol mase tampa vienalytė. Maišymo įrenginyje paruošta masė ne tik maišoma, bet dažnai ir vakuumuojama. Sumaišyta masė liejimo kaušu supilstoma i formas. Formos vibruojamos, dèl to jos užsipildo tolygiai, nelieka tuščių ertmių. Formuojant polimerbetonį būtina atsižvelgti i susitraukima, nors poliesterio dervos su priedais susitraukimas yra palyginti labai mažas $-0,3-0,5 \%$.

Norint paspartinti kietinimo procesa, produktą galima apdoroti termiškai. Juostinis transporteris medžiaga gabena į terminio apdorojimo kamera, kurioje vyksta polimerizacija. Pradžioje formos su produktu temperatūra pakyla iki $60-70{ }^{\circ} \mathrm{C}$. Vèliau ji pakeliama iki $90{ }^{\circ} \mathrm{C}$ temperatūros. Šioje temperatūroje produktas laikomas 1,52 val. Po terminio apdorojimo formos išardomos ir išimami gaminiai, atliekama vizualinè kokybès kontrolè ir šalinami smulkūs defektai. Gaminiai laikomi uždaro tipo sandèliuose ne mažiau kaip 3 paras ne žemesnèje kaip $18{ }^{\circ} \mathrm{C}$ temperatūroje. Polimerbetonis dažnai vadinamas dirbtiniu akmeniu. Iš jo gaminami stalviršiai ir kriauklès (jiems gaminti naudojami marmuro trupiniai), dvikomponenčiai glaistai ir gruntai, grindų plytelès, sienos plokštès (4.13 pav., b, c), vamzdžiai, vandens šalinimo sistemos (latakai 4.13 pav., a), laiptai, taip pat jis naudojamas rezervuarams hermetizuoti, grindims irengti.
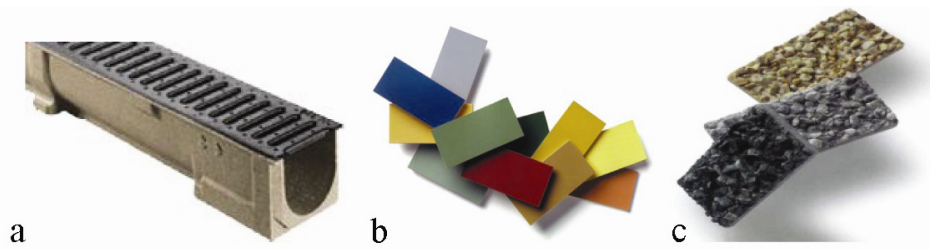

4.13 pav. Vandens latakas iš polimerbetonio su ketinèmis grotelèmis (a), fasadinès apdailos lygaus paviršiaus plokštès (b); fasadinès apdailos plokštès, padengtos natūralaus akmens grūdeliais (c) 


\subsection{Polimeriniai dirbiniai, armuoti pluoštais}

Didelę dalị kompozitinių polimerinių medžiagu grupëje užima dirbiniai, armuoti pluoštais. Gali būti naudojami stiklo, anglies, aramido, boro pluoštai.

Pluoštais armuoti plastikai - tai medžiagos, sudarytos iš $\sim 70 \%$ stiklo, anglies, aramido ar boro pluošto bei $\sim 30 \%$ polimerinio rišiklio (4.14 pav.). Kai kurios armuotų plastikų savybès pateiktos 4.2 lentelëje.

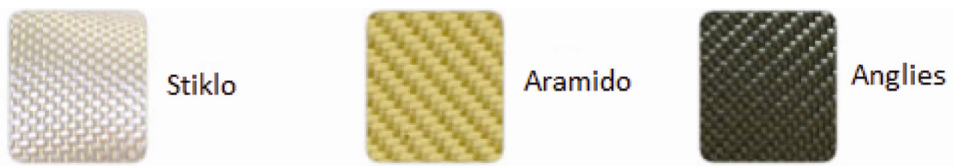

4.14 pav. Stiklo, aramido (kevlaro), anglies pluošto audiniai

Armuotuju plastikų stipris yra didesnis, o tamprumo modulis mažesnis nei plieninès armatūros. Stiprinant konstrukcijas armuotieji plastikai gali pakeisti plieną. Šių medžiagų privalumai, lyginant su plienu, yra šie: nedidelis tankis $\left(1-2 \mathrm{~g} / \mathrm{cm}^{3}\right)$ - stiprio ir tankio santykis apie 10-15 kartų didesnis už plieno; didelis atsparumas korozijai ir nuovargiui, veikiant dinaminèms apkrovoms, nedidelis temperatūrinès plètros koeficientas. Tačiau kaip ir visi plastikai šios medžiagos neatsparios ultravioletiniams spinduliams, todèl jų paviršius dengiamas specialia danga.

4.2 lentelè. Armuotų pluoštais plastikų savybès $\left(f_{\mathrm{c}}-\right.$ tempimo stipris, $E-$ tamprumo modulis, $\varepsilon_{u}$ - ribinis ištịsimas, $\alpha$ - temperatūrinès plètros koeficientas)

\begin{tabular}{c|c|c|c|c|c}
\hline $\begin{array}{c}\text { Pluošto } \\
\text { tipas }\end{array}$ & $\begin{array}{c}\text { Rišiklio } \\
\text { tipas }\end{array}$ & $\begin{array}{c}f_{\mathrm{c}}, \\
\mathrm{MPa}\end{array}$ & $\begin{array}{c}E, \times 10^{3} \\
\mathrm{MPa}\end{array}$ & $\begin{array}{c}\varepsilon_{\mathrm{u}}, \\
\%\end{array}$ & $\begin{array}{c}\alpha, \times 10^{-6} \\
\mathrm{~m} / \mathrm{m} /{ }^{\circ} \mathrm{C}\end{array}$ \\
\hline \multirow{2}{*}{ Anglies } & epoksidinis & $800-1800$ & $100-200$ & $1,2-1,6$ & 0,2 \\
\cline { 2 - 5 } & vinilestero & $1000-1100$ & $80-90$ & & \\
\hline \multirow{2}{*}{ Stiklo } & epoksidinis & $1300-1600$ & $40-50$ & $3,0-4,5$ & 7,0 \\
\cline { 2 - 4 } & vinilestero & $600-900$ & $30-40$ & & \\
\hline \multirow{2}{*}{ Aramido } & epoksidinis & $1200-1300$ & $60-65$ & $2,5-4,0$ & $2,0-5,7$ \\
\cline { 2 - 4 } & vinilestero & $1200-1900$ & $45-55$ & & \\
\hline
\end{tabular}


Stiklo pluoštas pasižymi dideliu stipriu ir mažu tamprumo moduliu. Yra įvairių stiklo pluošto variantų: E stiklas (mažo elektrinio laidumo), ECR stiklas (atsparus korozijai), S stiklas (padidinto stiprumo, 10-15\% stipresnis už E stikla), R stiklas, Te stiklas, silikono / kvarco stiklas (atsparus elektros išlydžiams), D stiklas ir kt. Išskyrus tekstilines armuojančiąsias medžiagas, šis pluoštas yra pigiausias.

Anglies pluoštas, palyginti su stiklo ir aramidiniu pluoštais, yra atsparesnis nuovargiui. Be to, anglies pluoštui, skirtingai nei stiklo ar aramidiniam, atskiru gijų iskilimai ir nutrūkimai nepavojingi, nes pluoštas supintas iš tūkstančių ar net šimtų tūkstančių labai plonų gijų.

Aramidiniai pluoštai iš visų komercinių pluoštų išsiskiria didžiausiu stipriu, tenkančiu svorio vienetui. Pagal tempimo stipri šis pluoštas artimas stiklo pluoštui, bet tamprumo modulis yra beveik du kartus didesnis.

Boro pluoštas pranoksta anglies pluoštą dideliu tamprumo moduliu. Pagal stipri jis nedaug skiriasi nuo stiklo pluošto, tačiau tamprumo modulis yra beveik penkis kartus didesnis. Šis pluoštas labai brangus, todèl naudojamas ribotai.

Konstrukciniams kompozitams gaminti geriausiai tinka termoreaktyvinès dervos. Tai dervos, kuriose dèl temperatūros arba kietiklių poveikio atsiranda negrižtamų cheminių pakitimų, todèl derva sukietejja, tampa netirpi ir nesilydo. Iš tokių termoreaktyvinių dervų galima paminèti šias: poliesterinès, vinilo esterio, epoksidinès, fenolinès dervos.

Poliesterinès dervos - labai plačiai naudojama medžiaga matricai. Dažniausiai ji komponuojama su stiklo pluošto armatūra. Matricos ir stiklo pluošto tarpusavio adhezija labai stipri. Kitu tipu pluoštai dèl prastos adhezijos su šia matricos medžiaga beveik nenaudojami.

Vinilo esterio dervoms kaip armatūra dažniausiai naudojamas stiklo pluoštas. Šios matricos kompozitai, lyginant su poliesterinès matricos kompozitais, yra lankstesni ir sunkiau lūžta. 
Epoksidinès dervos, lyginant su poliesterinemis ir vinilo esterinèmis dervomis, po liejimo mažiau traukiasi, pasižymi mažu lakumu, geru atsparumu tirpikliams ir aplinkos poveikiams, gera adhezija su daugeliu užpildų. Jos labai plačiai naudojamos oro transporto pramonejje naudojamiems dirbiniams gaminti.

Maleinimidinès dervos. Kai kurios iš šios matricos medžiagu gali būti naudojamos iki $300{ }^{\circ} \mathrm{C}$ temperatūros. Šios matricos kompozitai, naudojant anglies pluošta, dèl didelio higroterminio atsparumo yra laikomi pažangiausiais. Tačiau jie turi keletą trūkumų: yra trapūs, juose dažnai atsiranda mikroịtrūkiǔ, nors įtrūkių tikimybe gali būti sumažinta naudojant termoplastinius komponentus.

Poliamidinès dervos plačiausiai naudojamos aukštose temperatūrose naudojamiems gaminiams gaminti. Kol tampa trapios, jos ilga laiką gali būti naudojamos aukštesnèje kaip $300^{\circ} \mathrm{C}$ temperatūroje.

Geresnèmis temperatūrinèmis savybèmis pasižymi ir fenolinès dervos. Tačiau naudojant jas patiriama tu pačių sunkumų atsirandančiu dęl tuštumų formavimo. Šios dervos dažnai būna trapios ir gana prastų mechaninių savybių. Kompozitai su šių dervų matricomis dažniausiai naudojami ugniai atspariems gaminiams gaminti.

Cianoesterinès dervos pasižymi geromis elektrinèmis savybėmis ir yra naudojamos su mažo dielektriškumo pluoštais. Šios dervos igeria mažai drègmès ir yra stabilios iki $200^{\circ} \mathrm{C}$.

Polieterketoninès dervos dažniausiai naudojamos su ištisiniu anglies pluoštu. Jos pasižymi dideliu atsparumu smūgiams, geromis hidroterminèmis savybèmis, labai maža vandens absorbcija. Jų lenkimo stipris yra 100 kartų didesnis nei epoksidinių dervų.

Iš plastikų, armuotu pluoštais, gaminamos talpyklos, vamzdžiai, siurblinès, apšvietimo stulpai, armatūra, šie plastikai naudojami konstrukcijoms stiprinti ir atnaujinti. Tokie kompozitai labai atsparūs smūginèms ir ciklinèms apkrovoms, pasižymi hidrofobinèmis savybèmis, yra nelaidūs šilumai, o jų savybès nesikeičia iki $60^{\circ} \mathrm{C}$ temperatūros.

Be iprastinių cementinių, polimercementinių ar polimerinių klijų, mastikų, skiedinių, konstrukcijoms vis plačiau pradedami naudoti 
strypų, lynų, tinklų, audinių ar ivvairių profilių pavidalo armuotieji plastikai. Jų privalumai išryškèja tada, kai reikia patikimai sujungti elementus, apsaugoti betoną nuo smūgių, dilimo, šalčio ar agresyvios aplinkos.

Armuotujų plastikų stipris priklauso nuo adhezijos jègų tarp matricos polimero ir armuojančiosios medžiagos bei kohezijos jègu tarp matricos polimero makromolekulių. Kompozito matricos ir armuojančiosios medžiagos fazes skiria nuo 0,5 nanometro iki kelių tūkstančių nanomerų storio tarpsluoksnis. Šis tarpsluoksnis vadinamas tarpine faze. Kai kurios armuojančiosios medžiagos gali absorbuoti vandeni, kuris matricos susidarymo metu gali reaguoti su aktyviomis jos grupèmis. Tuomet greta armuojančiosios medžiagos atsiranda kita tarpinè fazè iš plastifikuoto matricos polimero. Šis sluoksnis blogina kompozito savybes. Tokia tarpinè fazè gali būti pašalinta armuojančiosios medžiagos paviršių hidrofobizuojant specialiomis dervomis.

Adhezijos jègas tarp polimero ir užpildo galima padidinti parenkant tinkamą užpildo formą, smulkumo laipsni, modifikuojant jo paviršių (hidrofobizuojant, prijungiant giminiškas grupes). Pavyzdžiui, i polietileną arba poliamidą pridèjus $30 \%$ stiklo pluošto, gaminio trūkimo stipris padideja $240 \%$. Tačiau, kai priedų kiekis viršija optimalų, kompozito stipris pradeda mažèti. Kompozitas stipriausias būna tada, kai armuojančiosios medžiagos paviršiuje sudaroma monomolekulinè orientuoto polimero plèvelè.

Tiriant îtrūkimų susidarymą armuotuosiuose plastikuose, nustatyta, kad jie mažesni, kita plastiką stiprinančio pluošto veikimo priežastis yra įtempio relaksacija, ittrūkiui pasiekus pluošto paviršių. Toliau toks defektas didèja tik didèjant mechaninei jègai.

Teisingai parinktos armuojančiosios medžiagos ne tik padidina kompozitinès polimerinès medžiagos stipri, bet ir pakeičia jos deformacines ir termines savybes, nes pluoštas mažiau deformuojasi nei matricos medžiaga.

Stiklaplasčiais vadiname stiklo pluoštu armuotą plastiką. Stiklo pluoštas šiuose kompozituose sustiprina plastikus, o sintetinès dervos 
sujungia stiklo pluoštą i bendrą sistemą. Stiklaplastis - tai medžiaga, sudaryta iš stiklo pluošto (4.15 pav.), kurio gali būti iki $70 \%$, ir polimerų (termoreaktyvinių polimerų dervos). Angliškai stiklo plastikas žymimas GRP (glass-reinforced plastic). Iš šios medžiagos gaminamos talpyklos, vamzdžiai, armavimo elementai langų ir durų profiliams, strypų, tinklų profiliai, mašinų, lèktuvų detalès ir t. t.

a

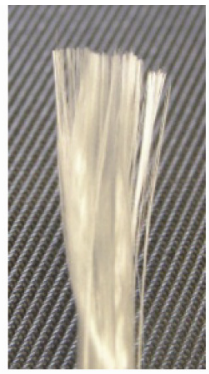

b

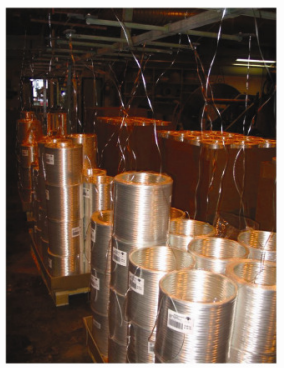

4.15 pav. Stiklo pluošto vaizdas: a - stiklo pluošto gija; $\mathrm{b}$ - stiklo pluošto ritès

Stiklo pluošto plaušeliai yra cilindrinès formos, lygaus paviršiaus ir lyginant su kitomis pluoštinèmis medžiagomis yra labai stiprūs. Plaušelių stipris priklauso nuo stiklo cheminès sudèties, lydalo homogeniškumo, formuojamo lydalo temperatūros, plaušelio storio, formavimo sąlygu ir būdo, plaušelio paviršiaus defektų. Stipriausi yra kvarcinio ir magnio bei aliuminio silikatinio stiklo plaušeliai, silpniausi - boro, fosfatinio, švino ir daug šarmų turinčio stiklo plaušeliai.

Plonėjant plaušeliui, mažèja pavojingų defektų susidarymo galimybè, todèl didejja jų tempimo stipris. Ilgesnių plaušelių tempimo stipris mažesnis, nes juose daugiau defektų. Mechaninėms savybėms labai didelę reikšmę turi plaušelių formavimo būdas ir sąlygos. Stipriausi yra dideliu greičiu pro filjeres iš lydalo ištempti plaušeliai; iš lazdelių arba pūtimo būdu ištempti štapeliniai plaušeliai yra silpnesni. Drègmè stiklo pluošte absorbuojama paviršiaus įtrūkomis ir paviršiaus defektais. Stiklo pluošto higroskopiškumas mažas - 0,2 \%. Drègmè ir aktyviosios paviršiaus medžiagos, absorbuotos plaušelių 
paviršiuje, skatina mikroịtrūkių susidarymą, o dèl jų, nepriklausomai nuo stiklo cheminès sudèties, 15-30 \% sumažèja plaušelių mechaninis stipris. Drègmè sumažina pluošto atsparumą lenkimui ir trynimui. Nepoliniai angliavandeniliai veikia analogiškai kaip ir sausas oras, t. y. didina plaušelių stiprị. Stiklo pluošto šiluminis atsparumas priklauso nuo stiklo cheminès sudėties. Bešarmio stiklo pluošto šiluminis atsparumas yra $700{ }^{\circ} \mathrm{C}$. Kaitinamo stiklo pluošto tempimo stipris didèja, nes plaušeliai tampa elastingesni, o dèl klampiosios deformacijos išnyksta paviršiniai mikrodefektai ir mikroįtrūkiai. Priklausomai nuo stiklo sudèties, keliant temperatūrą iki $500{ }^{\circ} \mathrm{C}$, stiklo pluošto tamprioji deformacija padideja 3-7 kartus. Apie stiklo pluošto atsparumą vandeniui, vandens garams, rūgštims, o ypač šarmams, sprendžiama iš masès nuostolių, skersmens ir stiprio pokyčių. Stiklo pluošto atsparumą šarmams didina cirkonio, aliuminio, geležies, cinko, alavo, lantano oksidai. Šarmams atspariu stiklo pluoštu dažnai armuojamos cemento ir polimerinès kompozicinès medžiagos. Kvarcinis, kaolino, taip pat bešarmis aliumoborosilikatinis pluoštas chemiškai yra gana atsparus vandeniui ir didelio slègio garui; šarmu turintis stiklo pluoštas yra neatsparus, jis ypač greitai ỹra, jei daug kartų apdorojamas vandeniu arba vandens garais. Kvarcinis, bešarmis neturintis boro ir aliumosilikatinis pluoštas yra atsparus rūgštims. Šilumai atspariems neorganinių polimerinių rišiklių kompozitams sudaryti naudojamas $300{ }^{\circ} \mathrm{C}$ ir aukštesnèje temperatūroje ortofosforo rūgščiai atsparus pluoštas.

Adhezinės (sukibimo) savybės yra svarbios armuojant stiklo pluoštu plastikus. Geriausiomis adhezinèmis savybèmis pasižymi kvarcinis, magnio-aliuminio silikatinis ir bešarmis aliumoborosilikatinis stiklo pluoštas. Silpniausiomis adhezinėmis savybėmis pasižymi silicio oksidu neturintis fosfatinis, boratinis, kadmio boratinis, taip pat švino silikatinis stiklo pluoštas. Norint padidinti polimerų ir stiklo pluošto adhezija, hidrofobinamas stiklo pluošto paviršius.

Didžiausi nesočiujų poliesterinių dervų kiekiai sunaudojami poliesteriniams stiklaplasčiams gaminti. Plastikui gaminti poliesterinè derva praskiedžiama vinilmonomeru (35-45 \%), dažniausiai naudo- 
jamas stirenas. Toks mišinys vadinamas nesočiuoju poliesteriu. Šiame mišinyje vinilmonomeras atlieka monomero vaidmeni, o poliesterinè derva - kietiklio. Norint gauti elastingesnę ir atsparią smūginèms apkrovoms ir ultravioletinei spinduliuotei medžiagą, stirenas maišomas su metakrilatu. Plastikas gaunamas pridedant polimerizacijos iniciatorių ir mišini kietinant. Kietinimo temperatūra gali būti $50-150{ }^{\circ} \mathrm{C}$, ji priklauso nuo polimerizacijos iniciatoriaus. Kaip iniciatorius gali būti benzoilperoksidas, cikloheksano rūgštusis peroksidas. Jei norima kietinti kambario temperatūroje, dedama kobalto naftenato mišinio arba peroksijunginiu ir tretinių aminų. Tam, kad susidarytų tinklinès makromolekulès, sunaudojama tik dalis poliesterinès dervos dvigubujų ryšių molekulių. Kitos molekulès, turinčios dvigubuosius ryšius, eksploatavimo metu gali reaguoti, tada plastikas tampa neatsparus vandeniui, sensta.

Derva greitai susigeria i stiklo audini, yra patogi naudoti dengiant rankomis ir purškiant. Storinant dirbini kelis kartus (esant tarpiniams kietejjimams) kiekviena operacija turi būti užbaigiama esant standartiniam dervos ir stiklo pluošto kiekiu santykiui. Storinant medžiagą (prieš dedant naują sluoksni) būsimo gaminio paviršius, turintis dervos perteklių, turi būti pašiauštas. Jeigu gaminys neapdorojamas abrazyvine medžiaga, intervalai tarp dviejų operacijų negali viršyti 48 val. İ dervos sudètị ịeina parafinas, kuris sukietejjusiai medžiagai suteikia nelimpantị paviršių.

Gamyboje naudojamas katalizatorius, kuris yra metiletilketono peroksido ir plastifikatoriaus tirpalas. Šis katalizatorius yra stabilus, todèl tinkamas naudoti karštiems kraštams. Jis kartu su kobalto greitikliu naudojamas kambario temperatūroje vykstančioms nesočiuju poliesterinių dervų reakcijoms pagreitinti. Katalizatoriaus kietejimo pradžios laikas (laikas iki drebučių susidarymo pradžios) ir kietejimo greitis nurodomas dervos techniniuose dokumentuose.

Gaminant stiklaplastị gali būti naudojamos pagalbinès medžiagos - užpildai, ịvairūs priedai, pigmentai. Užpildai mažina kietėjančio stiklaplasčio traukimąsi, gerina išvaizda, todèl sumažèja jo kaina. Paprastai kaip užpildai naudojami maltas kvarcas, žèručio milteliai, 
talkas, maltas grafitas, gipsas, kaolinas, kreida, dolomitas. Užpildai naudojami smulkiai sumalti, jie pasižymi maža absorbcine galia ir neturi įtakos dervai kieteti. Kaip priedai dažniausiai naudojami vadinamieji tiksotropiniai priedai - metalų (chromo, geležies, cinko) oksidai. Toks priedas įterpiamas i poliesterinę derva, kai reikia sumažinti jos takumą arba laikinai sustabdyti tekejjimą vertikaliu paviršiumi. Kaip dažantys priedai dažniausiai naudojami geležies, chromo, titano, cinko ir kiti oksidai. Norint nudažyti stiklaplasčio gamini balta spalva, imaišoma 10-14 \% titano oksido, dažant kitomis spalvomis dedama $1-5 \%$ oksidų.

Dirbiniai iš stiklaplasčio gali būti gaminami rankiniu ir automatiniu būdu. Kai gaminama rankiniu būdu, dirbinys formuojamas rankiniu velenèliu ant reikiamos formos modelio. Formos paviršius turi būti padengtas antiadhezine plèvele, polivinilo alkoholiu ar techniniu vazelinu. Proceso metu dirba du darbininkai. Vienas darbininkas purškia medžiagas purkštuvu, kitas voleliu tolygiai paskirsto žaliavas ant formos (4.16 pav.).

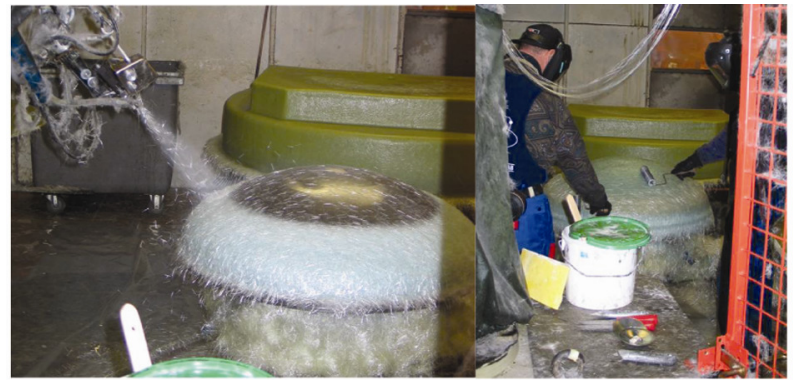

4.16 pav. Stiklaplasčio formavimas rankiniu būdu: kairèje - purškiamas kapoto stiklo pluoštas; dešinèje - voleliais lyginama masė

Purškiama ir voluojama vienu metu apie 10 min. Baigus purkšti dar 15-20 min. užpurkšta medžiaga voluojama ir lyginama. Nuo volavimo kokybès priklauso gaminio sienelès storis, o sienelès storis lemia gaminio stipri ir kokybę. Todèl šio proceso metu yra labai svarbu padengti formą vienodo storio sluoksniu. Kietejjančio dirbinio 
forma pakartotinai išlyginama velenèliu. Po 2 val. gaminys igauna pradini stiprị ir nuimamas nuo formos. Formos galvutèje yra pragręžta anga kompresoriaus žarnai, iš jos ir tiekiamas oras, kuris padeda atskirti suformuotą gamini nuo formos paviršiaus. Gaminys sukietėja per 48 val., tačiau jau po $2 \mathrm{~h}$ pradinis stipris yra pakankamas, kad gaminys galètų būti naudojamas kitose technologinès operacijose.

Kontaktiniu rankiniu būdu pagamintų dirbinių kokybė priklauso nuo prispaudimo ir išlyginimo operacijų, kurios atliekamos rankiniu būdu. Dèl blogo prispaudimo gali susidaryti oro intarpug, gali būti nevienodas dirbinio storis, taip pat tokių dirbinių stipris irgi gali būti mažesnis, nei formuojant automatiniu būdu.

Cilindrinès formos detalès gaminamos automatiniu vyniojimo būdu. Stiklo pluoštai, iš anksto įmirkyti polimere, automatiniu būdu vyniojami ant dirbinio formos (4.17 pav.). Labiausiai paplitusios spiralinè ir skersinè pluošto vyniojimo schemos. Pluošto juosta vyniojama spirale dirbiniui sukantis ir išilgai i abi puses judant pluošto juostos vyniojimo laikikliui. Vyniojant pluoštą skersai i vieną ir i kitą pusę dirbinys maksimaliai sustiprinamas.

Šiuo būdu pagaminti gaminiai yra aukštesnès kokybès, nes formuojant stiklaplasti gaunama mažesnè matmenų paklaida, tolygus sienelès storis, lengviau prognozuojamos kompozitinès medžiagos
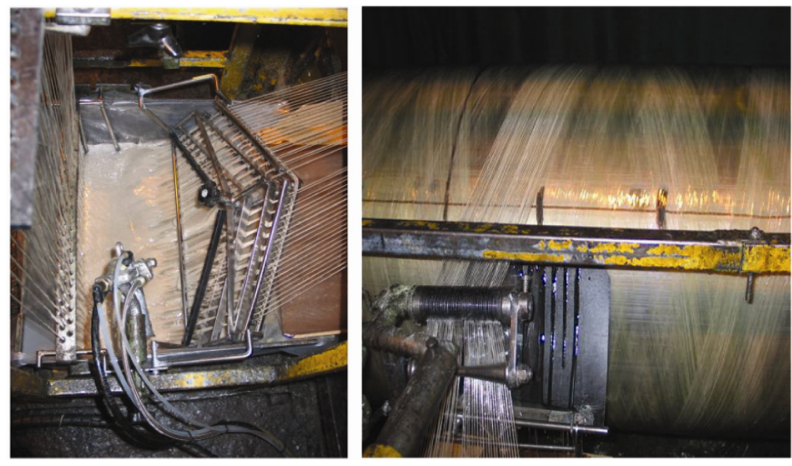

4.17 pav. Stiklaplasčio formavimas automatiniu būdu:

kairèje - stiklo pluošto įmirkymas dervoje; dešinèje - imirkytų pluoštų vyniojimas ant formos 
savybės: tempimo ir gniuždymo stipris. Šios technologijos privalumai: racionalus žaliavų naudojimas, mažesnès darbo sąnaudos, automatizuotas procesas, mažesni medžiagų nuostoliai lyginant su rankiniu gamybos būdu. Tačiau gaminant, pavyzdžiui, talpyklas, naudojamas ir rankinis, ir automatinis formavimo procesai, nes talpyklos cilindras gali būti pagamintas automatiniu būdu, o jos šonai, kojelès, prijungimo vietos - rankiniu būdu.

Gaminant automatiniu būdu derva ir kietiklis siurbliu pumpuojami iš talpyklų. Skystos žaliavos žarnomis patenka i purkštuva, jame derva ir kietiklis dozuojami pagal nustatytas proporcijas. Dozuoti skysčiai tiekiami i purkštuvo galvutę, kurioje yra tolygiai sumaišomi ir visa sumaišyta mase purškiama i dervos vonelę. Sumaišytos skystos medžiagos pradeda kietėti po 35-45 minučių. Taigi maišymo ir automatinis vyniojimo procesas negali trukti ilgiau, nei ši nurodyta trukmè.

Stiklo pluošto gijų kiekis yra parenkamas priklausomai nuo gaminio matmenų ir paskirties. Kuo didesni stiprio reikalavimai keliami gaminiui, tuo gijų skaičius turi būti didesnis. Dažniausiai parenkamų gijų skaičius yra 40-50 vnt. Iš ritinèlių stiklo pluošto gijos surinkimo įrenginiu surenkamos i pluoštą. Prieš mirkant dervoje, pluošto gijos îtempiamos ịtempimo irrenginiu. Paskui surinktas pluoštas mirkomas vonelèje, dervos ir kietiklio mišinyje. Išmirkytas stiklo pluoštas vyniojamas ant paruoštos formos. Formos skersmuo parenkamas, priklausomai nuo reikiamų gaminio matmenų. Ivairių skersmenu gaminio formos laikomos gamyklos sandèlyje, o iš ten atvežamos ir užkeliamos ant automatinio vyniojimo įrenginio. Paruošus vyniojimo pagrindą ir žaliavas pradedamas vyniojimo procesas. Pradžioje paruošto stiklo pluošto gijos ittvirtinamos formoje. Technologinio proceso metu cilindrinè forma sukasi pagal laikrodžio rodyklę, o vežimèlis su stiklo pluoštu ir dervos vonele juda horizontaliai i kairę ir i dešinę reikiamu atstumu. Vyniojant skersiniu būdu, skersavimo kampas, tankumas ir vyniojimo intervalai parenkami priklausomai nuo gaminio paskirties. Stiklo gijų išdèstymas lemia gaminio stiprio savybes. Cilindrinis gaminio korpusas, priklausomai nuo eksploatavimo metu veikiančių apkrovų, gali būti gaminamas skir- 
tingo sienelès storio. Sienelès storis svyruoja nuo 8 iki $16 \mathrm{~mm}$. Tose vietose, kur apkrova yra didžiausia, stiklaplastis yra storesnis negu kitur, ir atvirkščiai, kur apkrovos mažesnès, sienelès storis projektuojamas mažesnis. Gaminant kiekvieną gaminị atskirai ir atsižvelgiant tik i jam būdingas savybes, taupomos žaliavos, taip pat gaunamas individualus ir ypač kokybiškas gaminys.

Medžiagos vyniojimas ant paruoštos formos dažniausiai trunka iki 30 minučių, nes po tam tikro laiko prasideda mišinio kietejjimo reakcija. Kietejjimo pradžia priklauso nuo kietiklio savybių. Gaminant ypač didelių matmenų gamini, vyniojimo procesas užtrunka ilgiau, nei gaminant iprastų matmenų produkciją. Tada parenkamas toks kietiklis, kurio kietejjimo pradžia yra vèliau nei po 40 minučių.

Apvyniojus formą išmirkytomis gijomis, atliekama paskutinè vyniojimo proceso operacija - vyniojamos standumo briaunos. Jos vyniojamos stačiu kampu 1-1,7 m atstumu viena nuo kitos. Standumo juostos plotis varijuoja 50-100 mm. Standumo briaunos eksploatavimo metu suteikia gaminiui papildomą stiprị.

Suformuotą stiklaplasčio gaminio cilindrą reikia išlaikyti $2 \mathrm{~h}$ ant formos, kad kompozitas igautu pradinị stiprị ir jị būtų galima apdoroti. Pasibaigus laikymo trukmei, gaminys ištraukiamas iš formos ir kranu nukeliamas ant specialiu stovų i tą vietą, kur cilindras apdorojamas rankiniu būdu. Rankini apdorojimą sudaro keletas operacijų: nereikalingo stiklo plastiko apipjaustymas, šlifavimas, reikalingu skylių gręžimas. Automatiniu būdu pagamintame cilindre išpjaunamos kiaurymès, iklijuojamos papildomos detalès; jei gaminamos talpyklos, tai cilindras sujungiamas iš anksto pagamintomis talpyklos kraštinėmis sienelèmis.

Automatiniu formavimo būdu dažniausiai gaminami stiklaplasčio vamzdžiai, priešgaisrinès talpyklos, naftos produktų ar riebalų atskirtuvai (4.18 pav.).

Iš stiklaplasčio gaminami profiliai, kuriais armuojamos konstrukcijos arba jie naudojami medžiagų sluoksniams sujungti. Profiliai gaminami pultruzijos (ang. pultrusion) būdu (4.19 pav.). Ši gamyba - tai nenutrūkstamas procesas, kurio metu stiklo pluošto gijos 

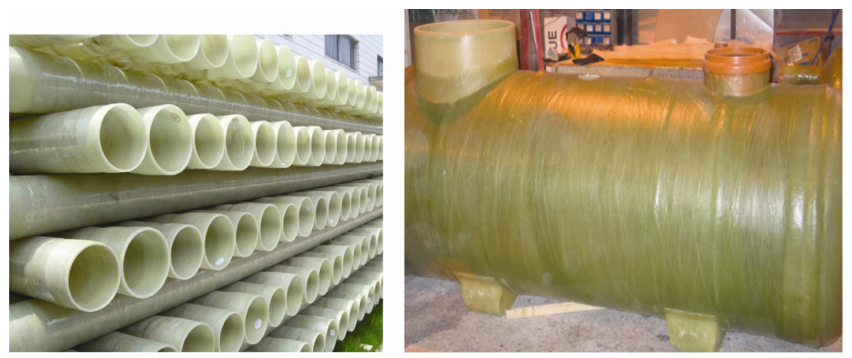

4.18 pav. Stiklaplasčio gaminių vaizdai: kairejje - vamzdžiai; dešinejje - talpyklos

impregnavimo vonioje impregnuojamos termoreaktyvinèmis dervomis. Dervos perteklius nuo pluošto nuspaudžiamas, pluoštas patenka i formavimo kamera, kurioje suformuojami ištisiniai profiliai. Profilių kietinimo procesas vyksta terminio apdorojimo kameroje, kurioje dervos sukietinamos.

Suformuotas stiklaplasčio profilis aušinamas ir supjaustomas $\mathrm{i}$ reikiamo ilgio strypus. Gamybinès linijos greitis gali siekti 7,6 m/min. Tam, kad profiliai būtų atsparesni ultravioletiniams saulès spinduliams ir aplinkos poveikiams, jų paviršius padengiamas papildomu pluoštu.

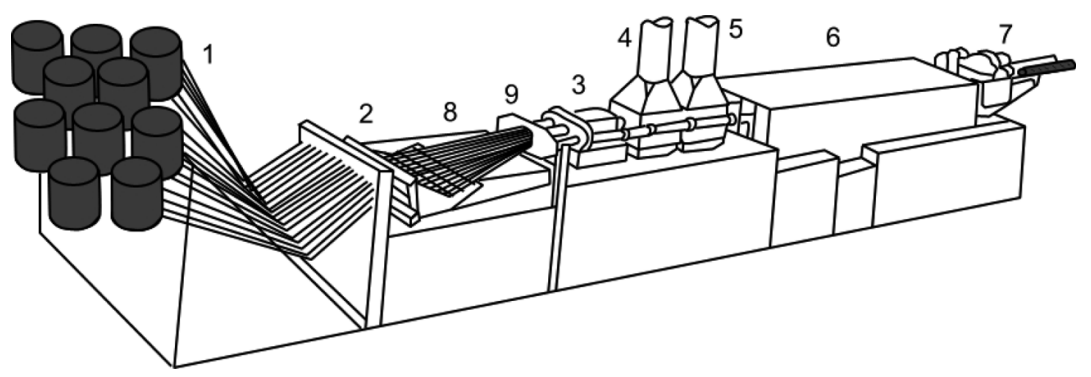

4.19 pav. Stiklaplasčio profilių principinè gamybos schema: 1 - stiklo giju rites; 2 - impregnavimo derva vonia; 3 - formavimo ir susukimo kamera; 4 - terminio apdorojimo kamera; 5 - aušinimo kamera; 6 - tempimo ir transportavimo irenginys; 7 - pjaustymo įrenginys; 8 -impregnuotas stiklo pluoštas; 9 - stiklo pluošto surinkimo įrenginys 
Iš stiklaplasčio profilių statyboje naudojami strypai, kurių paviršius gali būti lygus arba grublètas, padengtas užpildo dalelèmis, su įdubomis ar raižytas (4.20 pav.). Aprašytu būdu pagamintų profilių skersmuo gali būti iki $7,62 \mathrm{~cm}$.

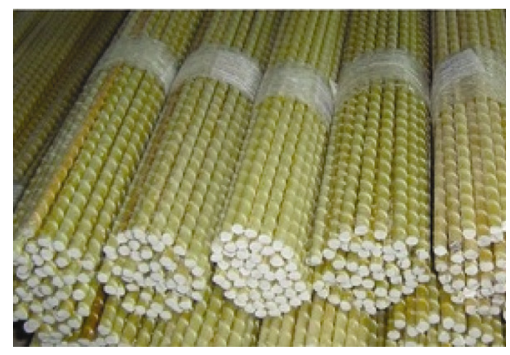

4.20 pav. Stiklaplasčio strypų vaizdas

Anglies pluoštu armuoti plastikai CRP, CFRP yra labai lengvos kompozitinès medžiagos, pasižyminčios labai dideliu stipriu, kurių tankis $1450 \mathrm{~kg} / \mathrm{m}^{3}$. Šios medžiagos naudojamos rečiau nei stiklaplasčiai dèl didelès kainos. Kaip ir kitų pluoštais armuotų kompozitų, šio kompozito savybès priklauso nuo naudojamos matricos medžiagos. Kaip matrica gali būti poliesterinès ar kitos dervos.

Anglies pluoštas gaunamas termiškai - 1000-3000 ${ }^{\circ} \mathrm{C}$ temperatūroje apdorojant sintetinius ar gamtinius organinius pluoštus (poliakrilonitrilinius, viskozinius). Kai apdorojimo temperatūra mažesnè nei $1000{ }^{\circ} \mathrm{C}$, tokioje medžiagoje yra $85-90 \%$ anglies, kai temperatūra $1000-1500{ }^{\circ} \mathrm{C}$, medžiagoje yra $95-99 \%$ anglies, kai temperatūra siekia $1500-3000{ }^{\circ} \mathrm{C}$, medžiagoje yra daugiau nei $99 \%$ anglies. Anglies gijos labai plonos, jų skersmuo 0,005-0,01 mm (4.21 pav.). Sulaužyti jas lengva, tačiau nutraukti labai sunku. Gaminant anglies pluoštą poliakrilnitrilo ar viskozinis pluoštas oksiduojamas $250{ }^{\circ} \mathrm{C}$ temperatūroje $24 \mathrm{~h}$. Po to vyksta karbonizacijos procesai: plaušai kaitinami $800-1500{ }^{\circ} \mathrm{C}$ temperatūroje azoto ar argono aplinkoje. Po karbonizacijos gaunamos grafito struktūros. Termiškai apdorojama $1600-3000{ }^{\circ} \mathrm{C}$ temperatūroje inertinèje aplinkoje. Pluoštui gaminti gali būti naudojamas ir pluoštas iš fenolinių dervų, lignino, akmens 


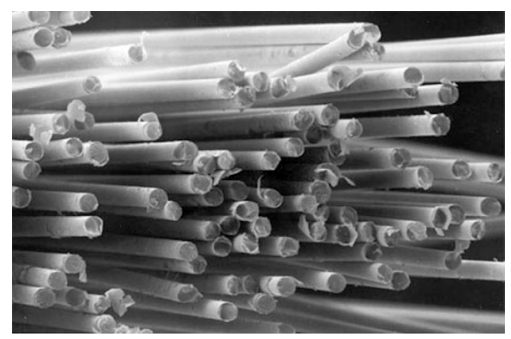

4.21 pav. Padidintas anglies pluošto vaizdas (poliakrilnitrilinis pluoštas)

anglies smèlio frakcijos. Aukšta pluošto savikaina priklauso nuo sudètingo gamybos proceso ir didelès žaliavų kainos.

Paprastai iš anglies gijų yra audžiami audiniai. Kad audinys būtų stipresnis, gaminant kompozitus jis dedamas sluoksniais, kurie tvirtinami dervomis. Audinys dedamas ant muilu, vašku ar kita nelimpančia medžiaga suteptos formos. Kiekvienas sluoksnis pasukamas tam tikru kampu ir tik tada dedamas ant prieš tai buvusio sluoksnio.

Gaminant anglies pluoštu armuotus plastikus, taikomas vakuumavimo procesas. Vakuumuojant iš derva sujungtų anglies pluoštu lengviau pašalinamas oras ir dervos likučiai. Oro burbuliukai gali bloginti gaminio kokybines charakteristikas. Vakuumuojama vakuumo maišuose ir / ar autoklavuose. Kai kurių dervų polimerizacija vyksta terminio apdorojimo metu. Anglies plaušu armuotų kompozitų gamybos procesas yra imlus rankiniam darbui, o gamybos našumas nedidelis. Gaminant vamzdžius ar kitus cilindrinès formos gaminius, forma padengiama anglies puošto ar audinio juostomis sukimo būdu.

Anglies pluoštu stiprinamos betono, mūro, plieno, ketaus ir medienos konstrukcijos. Konstrukcijos sustiprinamos apklijuojant anglies pluošto audiniu. Iš anglies pluošto pagaminta armatūra gali būti naudojama itemptojo betono gaminiams, kurie naudojami agresyviomis sąlygomis. Anglies pluoštu armuoti plastikai yra neatsparūs taškiniams daugkartiniams smūgiams, jie blunka saulèje. 


\section{Literatūra}

Balandis, A.; Kaminskas, R.; Vaickelionis, G. 2006. Statybiniu medžiagu chemija, III dalis. Organiniu statybiniu medžiagu chemija. Kaunas: Technologija. $79 \mathrm{p}$.

Bareišis, J.; Tričys, V. 2003. Polimeru ir kompozitu mechanika. Šiauliai: VŠI Šiaulių universiteto leidykla. $258 \mathrm{p}$.

Gailius, A.; Vèjelis, S. 2010. Termoizoliacinès medžiagos ir ju gaminiai. Vilnius: Technika. $170 \mathrm{p}$.

Kamaitis, Z. 2000. Gelžbetoniniu konstrukciju pleišejimas ir remontas. Vilnius: Technika. $168 \mathrm{p}$.

Klyosov, A. 2007. Wood-plastic composites. Wiley-Interscience. 239 p.

LST EN 13163:2003. Statybiniai termoizoliaciniai gaminiai. Gamykliniai polistireninio putplasčio (EPS) gaminiai. Techniniai reikalavimai. Vilnius: Lietuvos standartizacijos departamentas. 2003. 38 p.

LST EN 13164:2004. Statybiniai termoizoliaciniai gaminiai. Gamykliniai ekstruzinio polistireninio putplasčio (XPS) gaminiai. Techniniai reikalavimai. Vilnius: Lietuvos standartizacijos departamentas. 2004. $33 \mathrm{p}$.

ST 124555837.01:2005. Atitvaru šiltinimas polistireniniu putplasčiu. Putu polistirolo gamintoju ir vartotoju asociacija. Vilnius, 2005. $144 \mathrm{p}$.

Strazdas, K.; Eidukevičius, J. 1985. Mineralinis ir stiklo pluoštas. Vilnius: Mokslas. 222 p.

Šniuolis, R. 2004. Inžinerinès medžiagos. Šiauliai: Lucilijus. 255 p.

Žemaitaitis, A. 2001. Polimeru fizika ir chemija. Kaunas: Technologija. $567 \mathrm{p}$.

Olga KIZINIEVIČ, Ramunè ŽURAUSKIENĖ

INOVATYVIOS POLIMERINĖS STATYBINĖS MEDŽIAGOS IR DIRBINIAI

Mokomoji knyga

Redaktorè Nijole Žuvininkaitè

Maketuotoja Loreta Urbanavičiene

2012-05-08. 4,67 aut. l. Tiražas 120 egz.

El. versija pagal leidinio identifikatoriu doi:10.3846/1281-S

Vilniaus Gedimino technikos universiteto

leidykla „Technika“, Sauletekio al. 11, 10223 Vilnius

http://leidykla.vgtu.lt

Spausdino UAB „Ciklonas“, J. Jasinskio g. 15, LT-0111 Vilnius 